\title{
The Southeast Asian Pholcus halabala species group (Araneae, Pholcidae): new data from field observations and ultrastructure
}

\author{
Bernhard A. HUBER ${ }^{1, *}$, Booppa PETCHARAD ${ }^{2}$, Charles LEH MOI UNG ${ }^{3}$, \\ Joseph K.H. KOH ${ }^{4} \&$ Amir R.M. GHAZALI ${ }^{5}$ \\ ${ }^{1}$ Alexander Koenig Research Museum of Zoology, Adenauerallee 160, 53113 Bonn, Germany. \\ ${ }^{2}$ Department of Biology, Faculty of Science, Prince of Songkla University, Hat Yai, Songkhla 90112, Thailand. \\ ${ }^{3}$ Sarawak Museum, Jalan Tun Abang Haji Openg, 93566 Kuching, Sarawak, Malaysia. \\ ${ }^{4}$ National Biodiversity Centre, National Parks Board, 1B Cluny Road, Singapore 259598, Singapore. \\ ${ }^{5}$ Centre for Research and Consultancy, Unitar International University, Malaysia.

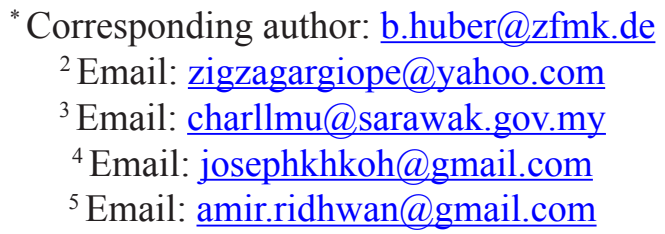 \\ ${ }^{1}$ urn:Isid:zoobank.org:author:33607F65-19BF-4DC9-94FD-4BB88CED455F \\ ${ }^{2}$ urn:Isid:zoobank.org:author:E1480A4E-3FA8-441C-A803-515B8AE7860D \\ ${ }^{3}$ urn:lsid:zoobank.org:author:BF48A807-815E-41E4-BCC6-F3A3FAEDBC9E \\ ${ }^{4}$ urn:lsid:zoobank.org:author:DA9CA194-2A90-41BD-8109-D8E536F23C0C \\ ${ }^{5}$ urn:Isid:zoobank.org:author:EA038837-AA7B-49F0-8012-2B23C36F1605
}

\begin{abstract}
The Southeast Asian Pholcus halabala species group is revised and re-delimited, based mainly on field observations (life color pattern, web design, position of egg-sac when carried by female, microhabitat) and ultrastructure (silk spigots, modifications of male cheliceral apophyses). The core group includes six leafdwelling species that have distinctive color patterns in life specimens (black and white or yellowish abdominal marks, dark pattern on posterior half of carapace) and build round to oval silk platforms on the undersides of leaves. Seven further species are tentatively assigned to the group pending further study. Several species originally assigned to the Pholcus halabala group are transferred to three newly proposed species groups, the Ph. krabi, Ph. buatong, and Ph. andulau groups. Nine species are newly described, four in the Ph. halabala group (Ph. khaolek Huber, sp. nov.; Ph. kuhapimuk Huber, sp. nov.; Ph. lintang Huber, sp. nov.; Ph. ubin Huber, sp. nov.); three in the Ph. krabi group (Ph. kipungit Huber, sp. nov.; Ph. krabi Huber, sp. nov.; Ph. narathiwat Huber, sp. nov.); one in the Ph. buatong group (Ph. buatong Huber, sp. nov.); and one in the Ph. andulau group (Ph. lambir Huber, sp. nov.). The females of Ph. satun Huber, 2011 and Ph. schwendingeri Huber, 2011 (both members of the buatong group) are newly described.
\end{abstract}

Keywords. Pholcus, taxonomy, web design, microhabitat, ultrastructure.

Huber B.A., Petcharad B., Leh Moi Ung C., Koh J.K.H. \& Ghazali A.R.M. 2016. The Southeast Asian Pholcus halabala species group (Araneae, Pholcidae): new data from field observations and ultrastructure. European Journal of Taxonomy 190: 1-55. http://dx.doi.org/10.5852/ejt.2016.190 


\section{Introduction}

With currently over 300 described species, the genus Pholcus Walckenaer, 1805 is by far the most species-rich genus in the Pholcidae (World Spider Catalog 2015). It includes some widespread and well-studied synanthropic species such as Ph. phalangioides (Fuesslin, 1775), but most of its diversity is concentrated in the Old World tropics and subtropics. For more than 200 years, almost any large pholcid with eight eyes and cylindrical abdomen resembling $P h$. phalangioides was assigned to this genus. As a result, a first attempt at revising the genus (Huber 2011) revealed some evidence for non-monophyly, with several genera (especially those containing leaf-dwelling taxa in Southeast Asia) apparently nested within a paraphyletic Pholcus. However, no nomenclature changes were formally proposed, partly because taxonomic sampling in the cladistic analysis seemed too preliminary, partly because some of the 29 species groups proposed seemed non-monophyletic themselves. In fact, the main focus of that revision was a first tentative division of this previously chaotic genus into more manageable units, which were explicitly proposed as "operational species groups".

One of the most problematic species groups in Huber (2011) was the Southeast Asian Pholcus halabala group. Only a core group of three species (Ph. halabala Huber, 2011; Ph. sabah Huber, 2011; Ph. sepaku Huber, 2011) was supported by fairly convincing synapomorphies. Eight further species were tentatively assigned to the group for lack of a better solution. The present paper is a first step towards resolving relationships among these species. Our main focus is on documenting some behavioral (web design, egg-sac position), ecological (microhabitat) and ultrastructural (spigots, male cheliceral apophyses) characters that are likely to be informative in future cladistic re-analyses of the genus.

\section{Material and methods}

Most of the material studied herein was collected during recent expeditions to northern Borneo (Jul.Aug. 2014) and the Malay Peninsula (Feb.-Mar. 2015). The material is currently deposited at the Princess Maha Chakri Sirinthorn Natural History Museum, Prince of Songkla University, Hat Yai (PSUZC), Thailand; the Sarawak Museum, Kuching (SMK), Malaysia; and the Zoologisches Forschungsmuseum Alexander Koenig, Bonn (ZFMK), Germany. Additional material came from the Netherlands Centre for Biodiversity Naturalis, Leiden (RMNH).

Methods and terminology used are as in Huber (2011). Measurements are in mm unless otherwise specified. Eye measurements are approx. $\pm 5 \mu \mathrm{m}$. Epigyna were cleared in a warm $\mathrm{NaOH}$ solution and stained with chlorazol black. For SEM photos, specimens were dried in hexamethyldisilazane (HMDS) (Brown 1993) and photographed with a Hitachi S-2460 scanning electron microscope. SEM data are presented within the descriptions but are not based on the holotype specimens described. Locality coordinates are in round brackets when copied from labels and original publications or when received directly from collectors, in square brackets when originating from some other source (such as online gazetteers, Google Earth, etc.). Distribution maps were generated with ArcMap 10.0.

The following abbreviations are used in the text:

$\mathrm{ALE}=$ anterior lateral eyes

$\mathrm{ALS}=$ anterior lateral spinnerets

$\mathrm{AME}=$ anterior median eyes

a.s.l. = above sea level

$\mathrm{L} / \mathrm{d}=$ length/diameter

$\mathrm{PME}=$ posterior median eyes.

In order to avoid confusion, Pholcus is abbreviated as "Ph." while Panjange is never abbreviated. Abbreviations used only in figures are explained directly in the figure legends. 


\title{
Results
}

\author{
Class Arachnida Cuvier, 1812 \\ Order Araneae Clerck, 1757 \\ Family Pholcidae C.L. Koch, 1851 \\ Pholcus Walckenaer, 1805
}

Pholcus Walckenaer, 1805: 80. Type species by (assumed) monotypy: Aranea phalangioides Fuesslin, 1775.

Pholcus - Huber 2011: 124-126.

Pholcus halabala species group

\section{Diagnosis}

The core group of six species (see below) includes medium-sized, long-legged spiders (body length $\sim 3-4$, male leg 1 length $\sim 30-40$ ); distinguished from other species groups in Pholcus by the combination of the following characters: elongate abdomen pointed dorso-posteriorly, with distinctive dorsal pattern of black and whitish or yellowish marks in life specimens (Figs 1-16; similar only in Ph. sudhami Huber, 2011, cf. Figs 54-56); eight eyes; male ocular area with conspicuous modified hairs (setae), which may appear as stiff bristles or stout curved spines, or both (Figs 19, 23, 43); male chelicerae with proximal and distal apophyses, distal apophyses with two cone-shaped teeth (modified hairs) each (Fig. 28); male bulb with uncus and appendix; procursus with distinctive dorsal flap (Fig. 35; absent in Ph. erawan Huber, 2011); epigynum weakly sclerotized, with 'knob'.

\section{Description - amendments}

The original description of the core group (Huber 2011) is still largely valid. The following can be added: male eye triads on low humps (Figs 18, 20, 43; i.e., not on short stalks as seen in Ph. krabi group) and only slightly wider apart than female eye triads $(1.2-1.5 \times)$; dorsal elongation of male palpal tarsus usually short and conical (asterisk in Fig. 30), long in Ph. erawan Huber, 2011 (fig. 1467 in Huber 2011); procursus usually with dorsal flap, absent in Ph. erawan; tibia 1 in males $\sim 6-9$, in females $\sim 6-8$; male gonopore with four epiandrous spigots (Figs 26, 44; confirmed in Ph. halabala and Ph. erawan); ALS with eight spigots each (one widened, one pointed, and six smaller cylindrically shaped spigots of varying sizes, Figs 25, 45; confirmed in Ph. halabala and Ph. erawan); web consists mostly of flat round platform closely attached to underside of leaf; web sometimes with large numbers of small silk tufts (Figs 4, 16; confirmed for Ph. halabala, Ph. erawan and Ph. sepaku); female holds egg-sac under body rather than in front of it (Figs 3, 5-6, 16; confirmed for Ph. halabala, Ph. erawan and Ph. sepaku).

\section{Composition}

The 13 species assigned to this group are here divided into two operational sub-groups: a core-group of six species for which the evidence for monophyly is considered to be strong (Ph. erawan Huber, 2011; Ph. halabala Huber, 2011; Ph. lintang Huber, sp. nov.; Ph. sabah Huber, 2011; Ph. sepaku Huber, 2011; Ph. ubin sp. nov.); and a sub-group of seven species whose assignment is tentative [Ph. elongatus (Yin \& Wang, 1981); Ph. exceptus Tong \& Li, 2009; Ph. khaolek Huber, sp. nov.; Ph. kuhapimuk Huber, sp. nov.; Ph. pakse Huber, 2011; Ph. pyu Huber, 2011; Ph. sudhami Huber, 2011].

The composition of the group changes as follows: to the original core group consisting of three species (Ph. halabala; Ph. sabah; Ph. sepaku) we add two newly described species (Ph. ubin Huber, sp. nov.; $P h$. lintang sp. nov.) as well as Ph. erawan. The latter species was originally part of another problematic species group (Pholcus quinquenotatus group; Huber 2011: 290). It lacks the distinctive dorsal flap 
on the procursus that is present in the other five species of the core group, and the hairs in the male ocular area are not particularly strong, but it is moved into the core group because (1) it builds the same distinctive web closely attached to the leaf surface as the five other species; (2) webs are provided with facultative silk tufts like in Ph. halabala and Ph. sepaku (otherwise only known in the African genus Smeringopus Simon, 1890; Huber 2012); (3) females carry the egg-sac under the body like $P h$. halabala and $P h$. sepaku, which is unique among Pholcidae; (4) life specimens have an almost identical distinctive pattern of large whitish to yellowish and black spots on the abdomen, and on the carapace a pair of V-marks; and (5) the procursus is provided with a distinctive retrolateral distal pocket also present in Ph. halabala (Figs 21-22, 41). Preliminary molecular data (A. Valdez-Mondragón, B.A.
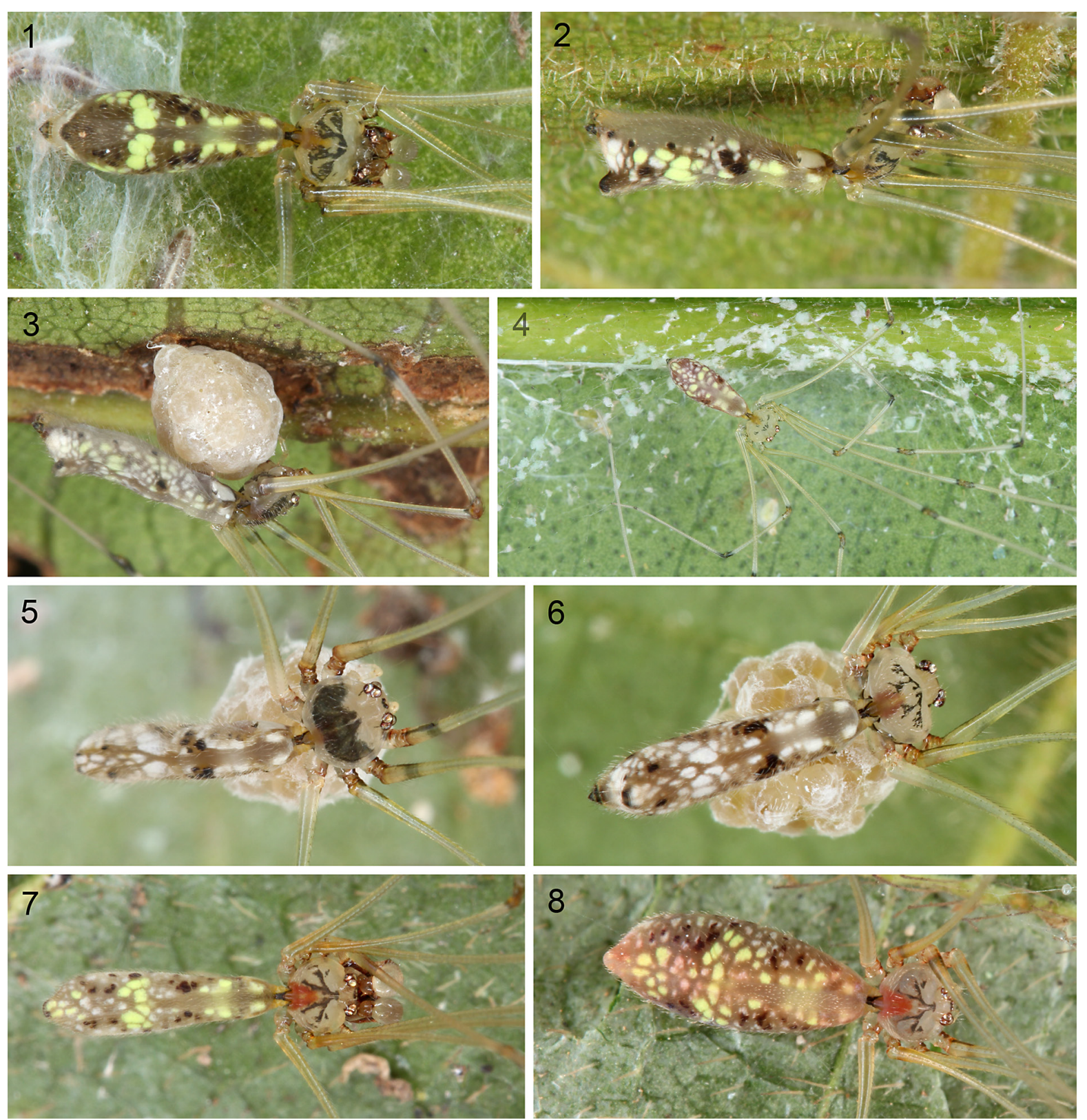

Figs 1-8. Live specimens, Pholcus halabala Huber, 2011 (1-6) and Ph. ubin Huber, sp. nov. (7-8). 1. $\overbrace{}^{\Uparrow}$ from MacRitchie, Singapore. 2. $\delta$ from Gunung Jerai, Malaysia. 3. + with egg-sac from Gunung Liang, Malaysia. 4. Juvenile in web with silk tufts, Upper Selatar, Singapore. 5. + with egg-sac from Hala Bala, Thailand. 6. $q$ with egg-sac from Ulu Dong, Malaysia. 7-8. $\overbrace{}^{\top}$ and $q$ from Pulau Ubin, Singapore. 
Huber \& D. Dimitrov unpublished data), including all species of the core group except $P h$. sepaku (i.e., also $P$ h. erawan), strongly support the monophyly of this group. The RMNH has three further species of the core group from Sabah (Fig. 17), but the specimens are poorly preserved and for this reason not formally described here.

In addition to this core group, we include in the $P h$. halabala group two further species that were previously part of the Pholcus quinquenotatus group (Ph. sudhami Huber, 2011; Ph. pakse Huber, 2011) as well as two newly described species (Ph. kuhapimuk sp. nov.; Ph. khaolek sp. nov.). Again, preliminary
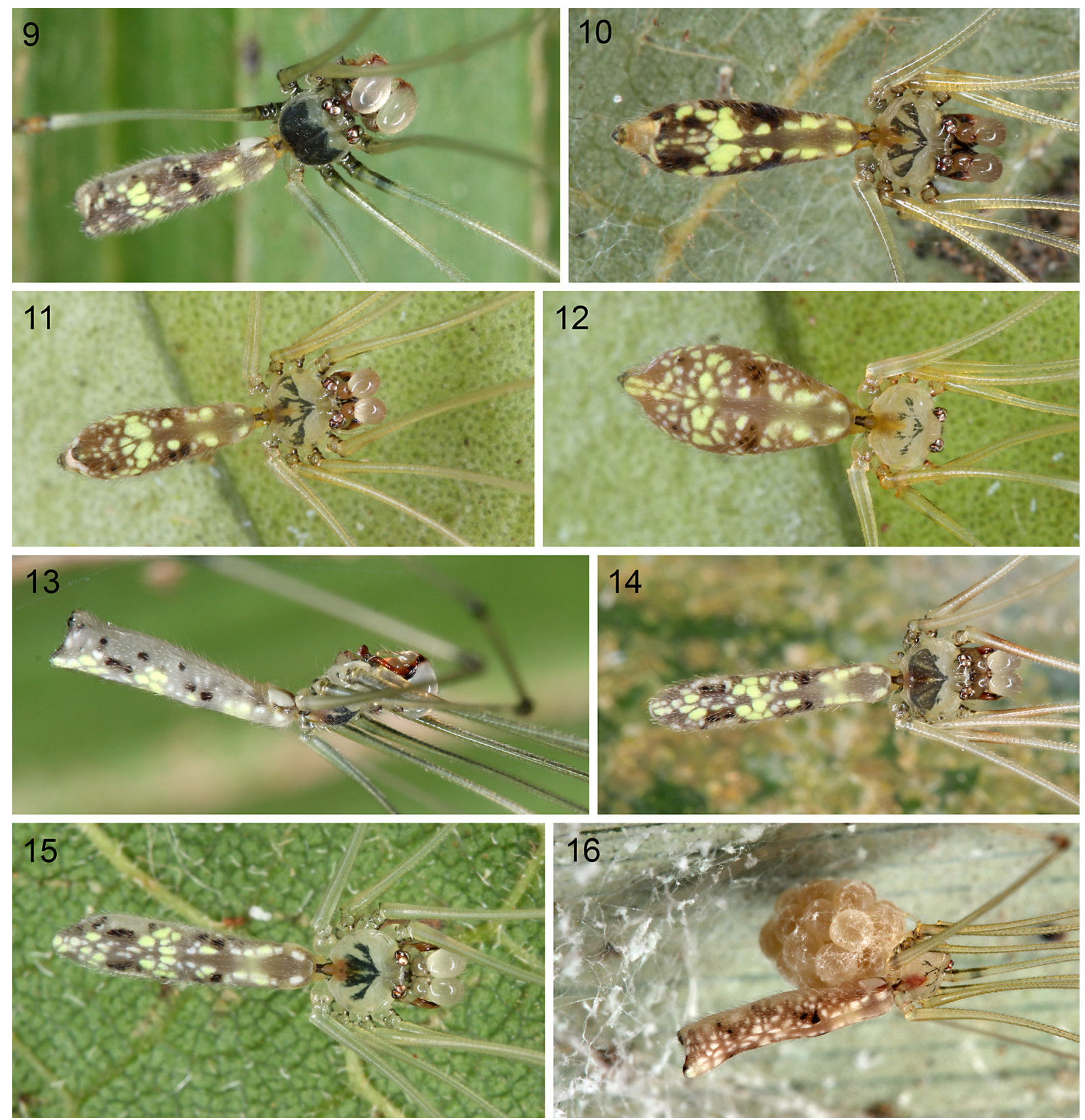

Figs 9-16. Live specimens, Pholcus sabah Huber, 2011 (9-10), Ph. lintang Huber, sp. nov. (11-12) and

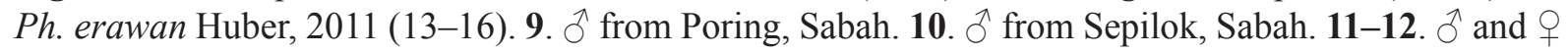
from Bako, Sarawak. 13. $\delta$ from Khao Nan, Thailand. 14. Male from Erawan, Thailand. 15-16. $\delta$ and + with egg-sac from Gunung Jerai, Malaysia. 
molecular data (A. Valdez-Mondragón, B.A. Huber \& D. Dimitrov unpublished data) strongly support a close relationship of these four species with the core group, and at least Ph. sudhami and Ph. pakse share some morphological similarities with the core group (carapace and abdomen pattern, male eye triads on low humps, large AME, male cheliceral apophyses with modified hairs), but no putative morphological synapomorphy is known that would support this close relationship. The microhabitat of these four species differs from the core group (rocks and tree roots rather than foliage); egg-sacs are carried in front of the body as in typical pholcids; webs were never seen to be provided with silk tufts. In addition, males of Ph. sudhami and Ph. pakse lack stronger hairs in the ocular area, and both species lack the bulbal appendix.

Three species originally assigned to the halabala group are kept in the group simply for the lack of a better solution: Ph. pyu Huber, 2011; Ph. elongatus (Yin \& Wang, 1981); and Ph. exceptus Tong \& $\mathrm{Li}, 2009$. Data on natural history and ultrastructure are not available for any of them, nor is any of them included in our preliminary molecular analysis (A. Valdez-Mondragón, B.A. Huber \& D. Dimitrov unpublished data). We speculate that $P h$. pyu may in fact belong to this group, but the other two species are quite certainly misplaced. Pholcus elongatus lacks AME; males in this species have short eye stalks and

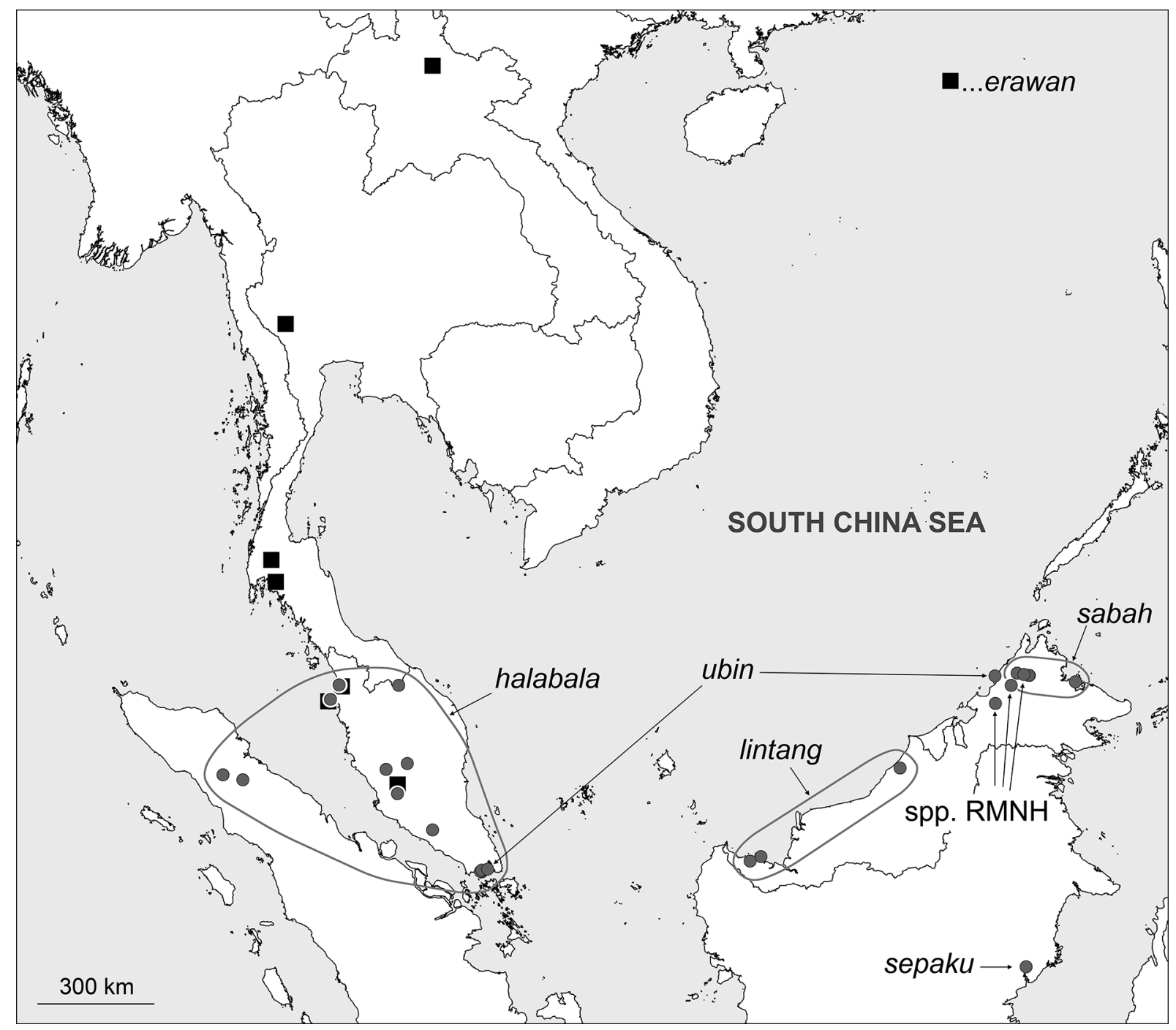

Fig. 17. Known distribution of the core group of the Pholcus halabala species group. 
pointed cheliceral apophyses without modified hairs; females have a long epigynal scape. We speculate that the closest relatives of Ph. elongatus are the Taiwanese species Ph. pingtung Huber \& Dimitrov, 2014 and Ph. chengpoi Huber \& Dimitrov, 2014 (six eyes; similar cheliceral apophyses; scape directed toward anterior). Pholcus exceptus is a mysterious species with entirely reduced distal cheliceral apophyses.

Finally, five species originally included in the Pholcus halabala group are transferred to new species groups (see below): Ph. andulau Huber, 2011; Ph. chiangdao Huber, 2011; Ph. khene Huber, 2011; Ph. kinabalu Huber, 2011; and Ph. satun Huber, 2011.

\section{Natural history}

All six species of the core group were observed in the field. At most localities, abundances seemed very low. Surprisingly, several species were partly or exclusively found in degraded forests. All specimens seen during the day were tightly pressed against the undersides of mostly large leaves. Webs consisted mainly of round platforms with a diameter of about $10 \mathrm{~cm}$; most of the platform was closely attached to the leaf surface. Small silk tufts (Figs 4, 16) were observed in some webs of three species $(P h$. halabala; Ph. erawan; Ph. sepaku), but may occur in other species as well (very few specimens seen in other species). The same applies to the peculiar position in which egg-sacs are held by females: in $P h$. halabala, Ph. erawan and Ph. sepaku (and possibly in close relatives), the egg-sac is carried under the prosoma rather than in front of it (Figs 3, 5-6, 16). For further details, see individual species descriptions below.

Three of the four species assigned tentatively to the halabala group based on preliminary molecular data were observed in the field (Ph. kuhapimuk sp. nov.; Ph. khaolek sp. nov.; and Ph. sudhami), and these were mostly found on rocks at cave entrances, with the body flat on the rock surface. Only Ph. sudhami at Erawan was mostly found on exposed tree roots at the riverside. Webs were either barely visible (a few threads close to the rock surface) or consisted of very delicate small domed sheets attached to the rock (Ph. khaolek sp. nov.). Silk tufts were not seen in any of these webs. Egg-sacs were carried in front of the body as in typical pholcids (Fig. 51).

\section{Distribution}

The Ph. halabala group is restricted to Southeast Asia, from Myanmar and southern China to Sumatra and Borneo (Figs 17, 57).

Pholcus halabala Huber, 2011

Figs 1-6, 18-28

Pholcus halabala Huber, 2011: 128-131, figs 495-496, 517-518, 530-535 (ð̊ㅇ).

\section{Diagnosis}

Easily distinguished from most other species in halabala core group by simple triangular uncus and short curved appendix with simple rounded tip (fig. 530 in Huber 2011; Fig. 24), and by distinctive sclerite anteriorly in internal female genitalia (fig. 533 in Huber 2011; similar in Ph. lintang sp. nov, cf. Fig. 37); from very similar Ph. sepaku only by shape of procursus (distinctive distal elements; compare figs 535 and 536 in Huber 2011).

\section{New material examined}

THAILAND: 1 + , 2 juvs, in absolute ethanol, ZFMK (Mal 302, 315), Narathiwat, Hala Bala Wildlife Sanctuary, 'site 1', forest at river near headquarters $\left(5^{\circ} 47.8^{\prime} \mathrm{N}, 101^{\circ} 49.9^{\prime} \mathrm{E}\right), 90 \mathrm{~m}$ a.s.1., on leaves, 1-2 Mar. 2015 (B.A. Huber, B. Petcharad). 
MALAYSIA: $1 \delta^{\widehat{ }}$ in ZFMK (Ar 15000), Kedah, Gunung Jerai, forest near Sri Perigi Waterfall ( $5^{\circ} 48.3^{\prime} \mathrm{N}$, $\left.100^{\circ} 24.6^{\prime} \mathrm{E}\right), 100-200 \mathrm{~m}$ a.s.l., on leaf, 27 Feb. 2015 (B.A. Huber); 1 juv., in absolute ethanol, ZFMK (Mal 292), same data; 1 ô, 1 , ZFMK (Ar 15001), Pulau Pinang, Penang National Park near Teluk Bahang $\left(5^{\circ} 27.7^{\prime} \mathrm{N}, 100^{\circ} 12.1^{\prime} \mathrm{E}\right), 10-50 \mathrm{~m}$ a.s.1., on leaves, $28 \mathrm{Feb} .2015$ (B.A. Huber); $1 \partial^{\lambda}$, in absolute ethanol,

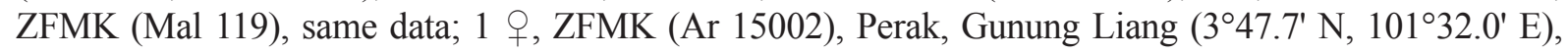
$250 \mathrm{~m}$ a.s.l., forest along river, on leaf, 22 Feb. 2015 (B.A. Huber, A.R.M. Ghazali, K.A. Braima); 2 우, 1 juv., in absolute ethanol, ZFMK (Mal 268), same data; 1 ô, ZFMK (Ar 15003), Pahang, Ulu Dong $\left(3^{\circ} 56.2^{\prime} \mathrm{N}, 102^{\circ} 01.9^{\prime} \mathrm{E}\right), 190 \mathrm{~m}$ a.s.l., forest near river, on leaf, 21 Feb. 2015 (B.A. Huber, A.R.M. Ghazali, K.A. Braima); 1 q, in absolute ethanol, ZFMK (Mal 253), same data; $1 \hat{\jmath}$, ZFMK (Ar 15004), Selangor, Kemensah ( $\left.3^{\circ} 13.31^{\prime} \mathrm{N}, 101^{\circ} 47.57^{\prime} \mathrm{E}\right), 230 \mathrm{~m}$ a.s.l., forest along stream, on leaf, 19 Feb. 2015 (B.A. Huber, A.R.M. Ghazali, K.A. Braima, M. Muslimin); $2 \hat{\jmath} \hat{\partial}, 1$ q, ZFMK (Ar 15005), Johor, Gunung Ledang, forest near Puteri Falls $\left(2^{\circ} 21.2^{\prime}-2^{\circ} 21.6^{\prime} \mathrm{N}, 102^{\circ} 37.8^{\prime}-102^{\circ} 38.1^{\prime} \mathrm{E}\right), 100-300 \mathrm{~m}$ a.s.l., on leaves, 17 Feb. 2015 (B.A. Huber); 1 + , 4 juvs, in absolute ethanol, ZFMK (Mal 239), same data; 2 우, ZFMK (Ar 15006), Gunung Ledang, forest near Puteri Falls ( $\left.2^{\circ} 21.3^{\prime} \mathrm{N}, 102^{\circ} 38.1^{\prime} \mathrm{E}\right), 110 \mathrm{~m}$ a.s.l., on leaves, 18 Feb. 2015 (B.A. Huber), night collecting; 1 juv. in absolute ethanol, ZFMK (Mal 244), same data.

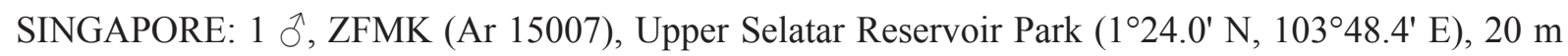
a.s.l., on leaf, 15 Feb. 2015 (B.A. Huber, D. Court); 3 juvs, in absolute ethanol, ZFMK (Mal 224), same data; 2 o $^{\top}$, ZFMK (Ar 15008), Dairy Farm Nature Park ( $\left.1^{\circ} 21.6^{\prime} \mathrm{N}, 103^{\circ} 46.7^{\prime} \mathrm{E}\right), 50 \mathrm{~m}$ a.s.1., on leaves, 15 Feb. 2015 (B.A. Huber, J. Koh); 1 q, 2 juvs, in absolute ethanol, ZFMK (Mal 214), same data; $2 \widehat{\delta} \delta^{\circ}$,

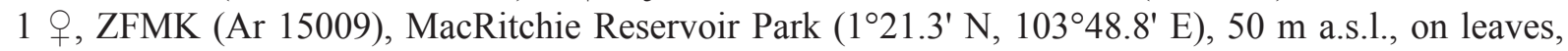
14 Feb. 2015 (B.A. Huber, J. Koh, D. Court); 1 \&, 4 juvs, in absolute ethanol, ZFMK (Mal 201), same data.

INDONESIA: 1 ๙ , 1 †, 1 juv., RMNH, Sumatra, Gunung Leuser National Park at Bohorok $\left[3.54^{\circ} \mathrm{N}\right.$, 98.12 $\left.{ }^{\circ} \mathrm{E}\right], 1000 \mathrm{~m}$ a.s.1., from leaves, $7-10$ Aug. 1982, collector unknown.

\section{Description - amendments}

Male ocular area on each side with four strong spines (Figs 18-20); apparently without gland openings (Fig. 23); tarsus 4 comb-hairs of the simplified Pholcus-type (cf. Huber \& Fleckenstein 2008), with three lateral tines (Fig. 27); procursus with retrolateral distal pocket (Figs 21-22); distal cheliceral apophyses with two cone-shaped teeth (modified hairs) each (Fig. 28); gonopore with four epiandrous spigots (Fig. 26); ALS with one widened, one pointed, and six smaller cylindrically shaped spigots of varying sizes (Fig. 25).

\section{Variation}

Previously, this species was known only from southern Thailand (type locality) and Sumatra (Huber 2011). Specimens from Sumatra were assigned tentatively because of minor differences in the procursus. The new specimens above support the idea that this is intraspecific variation rather than an indication of species limits. First, the ventral distal spine of the procursus varies continuously among localities, with specimens from Singapore having a short spine like specimens from Sumatra, and specimens from Malaysia being intermediate between those from Singapore and Thailand. Most deviating are specimens from Pulau Pinang, where the ventral distal process of the procursus carries three spines instead of only one. Second, the shape of the dorsal process of the procursus varies strongly with the angle at which it is viewed. If the procursus is viewed in slightly dorsal view, the process looks as in the original description (Huber 2011, fig. 531); if the procursus is viewed in perfect retrolateral view, the process appears slightly wider.

The usual pattern on the carapace consists of two V-marks on the posterior half (Figs 1, 6). In some specimens, these marks are fused into larger marks or even into a single large mark that covers the entire 

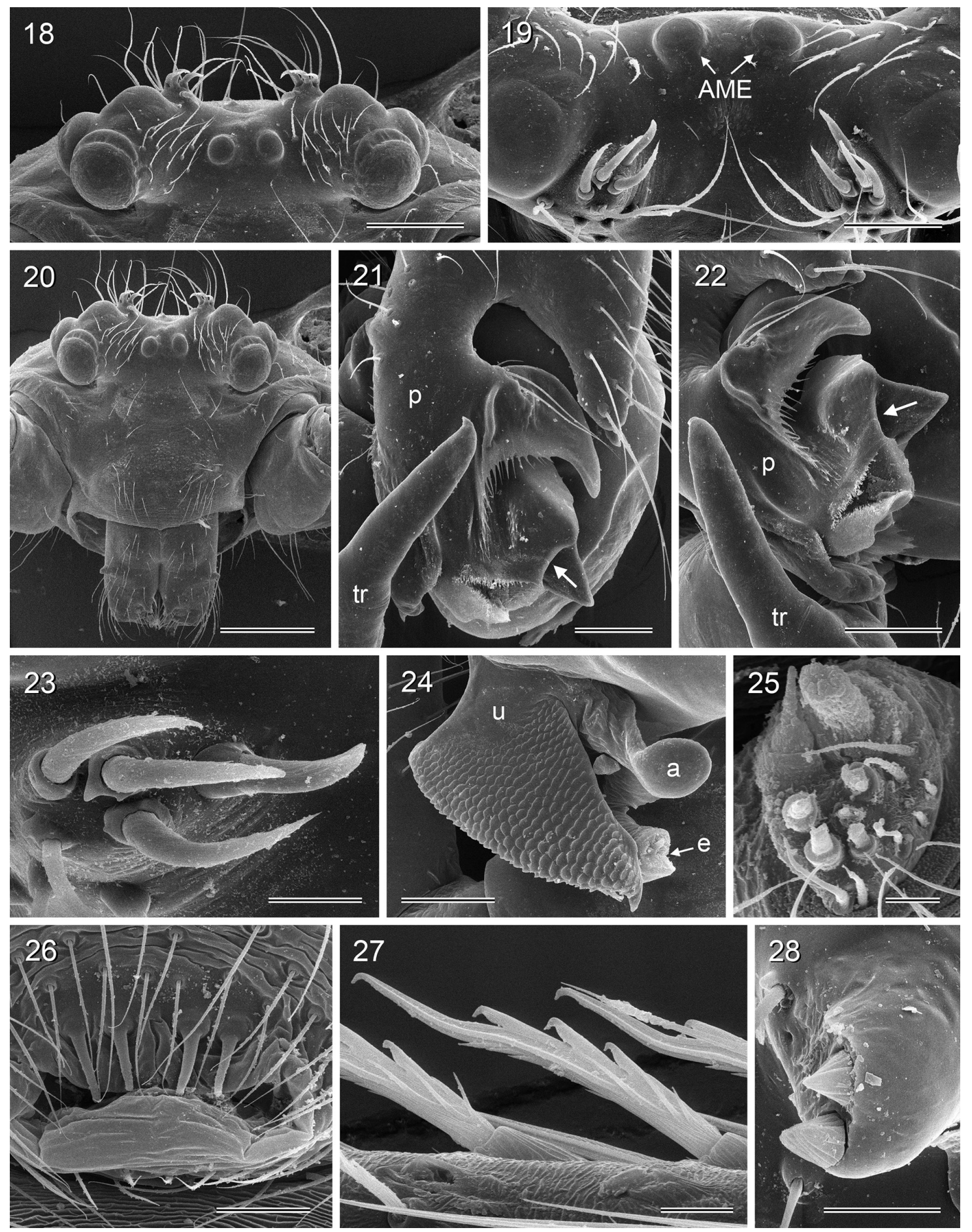

Figs 18-28. Pholcus halabala Huber, 2011, ZFMK Ar 15008. 18. Male ocular area, frontal view. 19. Modified hairs on male ocular area, dorsal view. 20. Male prosoma, frontal view. 21-22. Right procursus (and trochanter apophysis), retrolateral and retrolatero-distal views (arrows point at distal pocket). 23. Modified hairs on male ocular area. 24. Left bulbal processes, prolateral (slightly ventral) view. 25. Male ALS. 26. Male gonopore. 27. Comb-hairs on male tarsus 4. 28. Male distal cheliceral apophysis. Abbreviations: $\mathrm{a}=$ appendix; $\mathrm{AME}=$ anterior median eyes; $\mathrm{e}=$ embolus; $\mathrm{p}=$ procursus; $\operatorname{tr}=$ trochanter; $\mathrm{u}=$ uncus. Scale lines: $10 \mu \mathrm{m}(25,27) ; 20 \mu \mathrm{m}(28) ; 30 \mu \mathrm{m}(23) ; 40 \mu \mathrm{m}(26) ; 80 \mu \mathrm{m}(24)$; $100 \mu \mathrm{m}(19,21-22) ; 200 \mu \mathrm{m}(18) ; 300 \mu \mathrm{m}(20)$. 
posterior half of the carapace (Fig. 5). Tibia 1 in newly collected specimens: 12 males: 7.0-9.1 (mean 8.0); 6 females: 6.4-7.7 (mean 7.0).

\section{Natural history}

Even though this species is widespread, it seemed to be extremely rare at most localities. This explains the low specimen numbers even though it was searched for with considerable effort. At the type locality, three days of intensive search yielded only one female and two juveniles. The ATOL Expedition in 2003 (including several experienced arachnologists using a variety of collecting techniques) also found only one adult specimen. At some localities (Gunung Jerai; Penang), Ph. halabala was found together with $P h$. erawan, but $P h$. halabala seemed to prefer dicot leaves while $P h$. erawan was mostly found on monocot leaves. Otherwise these two species are barely distinguishable in the field. Webs consisted mainly of round platforms attached to the undersides of leaves. Small silk tufts (Fig. 4) were observed in some webs at most localities. Egg-sacs are carried under the prosoma (Figs 3, 5-6).

\section{Distribution}

Widely distributed from southern Thailand to Singapore and Sumatra (Fig. 17).

$$
\begin{aligned}
& \text { Pholcus ubin Huber, sp. nov. } \\
& \text { urn:1sid:zoobank.org:act:5EC32BD5-FE22-45DE-A5EB-7659D61FFC03 }
\end{aligned}
$$

Figs 7-8, 29-33, 90-92

\section{Diagnosis}

Easily distinguished from putatively closest known relatives (other species in the halabala core group) by morphology of male palps (Figs 29-30; procursus with heavily sclerotized dorsal process distally; shapes of uncus and appendix) and by female internal genitalia (Figs 32-33; triangular pore plates).

\section{Etymology}

The species name is derived from the type locality; noun in apposition.

\section{Type material}

SINGAPORE: holotype, Ô, ZFMK (Ar 15010), Pulau Ubin, degraded forest near park headquarters $\left(1^{\circ} 24.2^{\prime} \mathrm{N}, 103^{\circ} 58.2^{\prime} \mathrm{E}\right), 20 \mathrm{~m}$ a.s.1., on leaves, 16 Feb. 2015 (B.A. Huber, J. Koh, D. Court).

\section{Other material examined}

SINGAPORE: $2 \hat{\jmath} \widehat{\jmath}, 3$ 우, ZFMK (Ar 15011), same data as holotype; 2 $q$,, 3 juvs, in absolute ethanol, ZFMK (Mal 232), same data.

MALAYSIA-BORNEO: 1 §, RMNH, Sabah, Gaya Island ( $\left.6^{\circ} 00.90^{\prime} \mathrm{N}, 116^{\circ} 01.17^{\prime} \mathrm{E}\right), 22$ Aug. 2009 (A. Floren).

\section{Description}

\section{Male (holotype)}

Measurements. Total body length 4.1, carapace width 1.0. Leg 1: $30.4(7.3+0.4+7.2+14.2+1.3)$, tibia 2: 4.7, tibia 3: 2.7, tibia 4: 3.9; tibia $1 \mathrm{~L} / \mathrm{d}: 86$. Distance PME-PME $220 \mu \mathrm{m}$, diameter PME $95 \mu \mathrm{m}$, distance PME-ALE $\sim 35 \mu \mathrm{m}$; distance AME-AME $35 \mu \mathrm{m}$; diameter AME $60 \mu \mathrm{m}$.

COLOR. Carapace ochre-yellow with brown pattern of radiating marks posteriorly, in live specimens with reddish color in median area between posterior marks (Fig. 7); ocular area and clypeus not darkened; sternum with some dark marks posteriorly; legs ochre-yellow with dark brown patellae and tibia- 
metatarsus joints; abdomen pale ochre-gray with small black and white marks dorsally and laterally, monochromous ventrally.

BoDy. Habitus as in Fig. 7; ocular area slightly raised, with brushes of $\sim 10$ stronger hairs behind each PME; carapace without median furrow; clypeus unmodified; sternum wider than long $(0.62 / 0.40)$, unmodified.

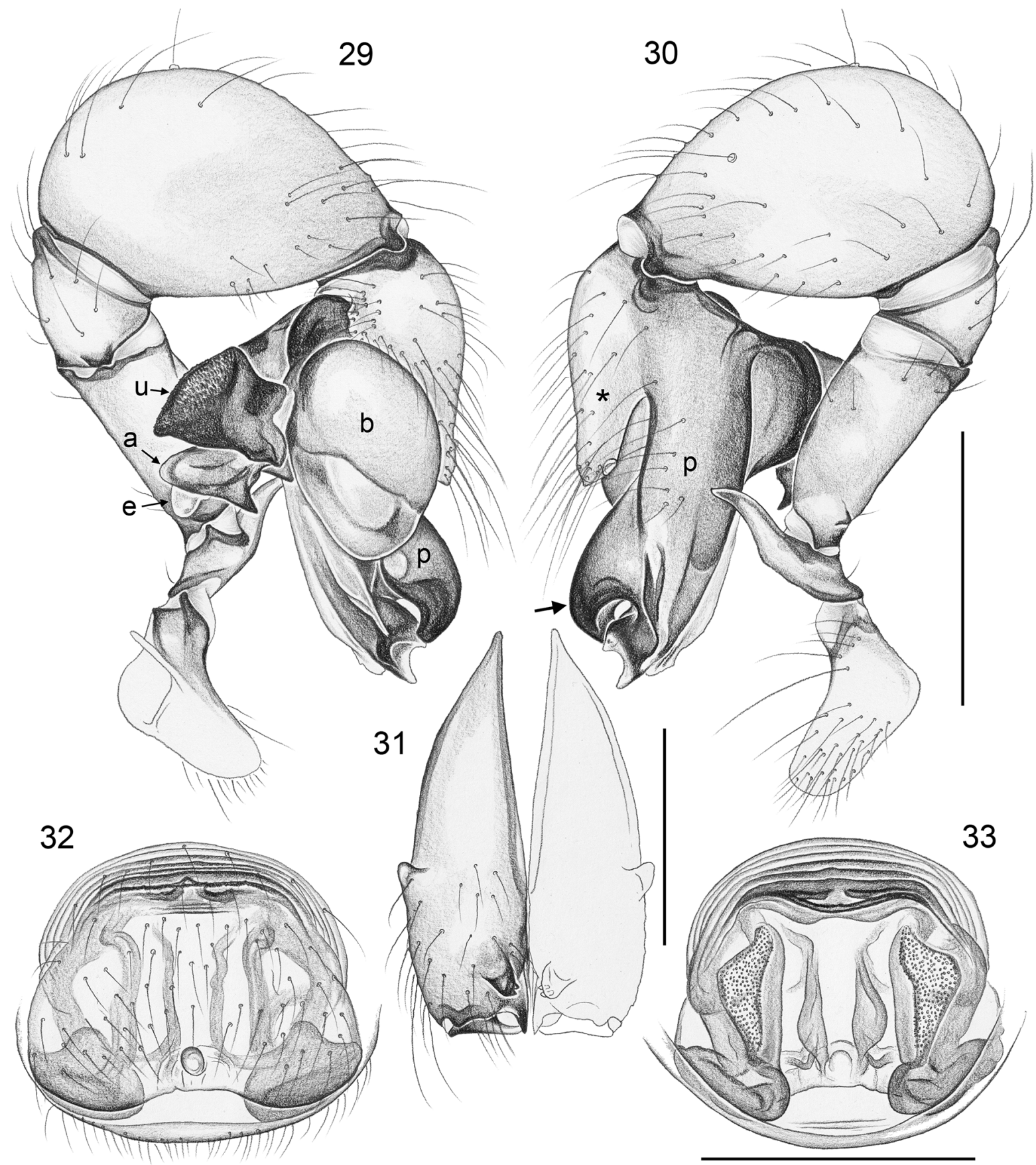

Figs 29-33. Pholcus ubin Huber, sp. nov., ZFMK Ar 15011. 29-30. Left male palp, prolateral and retrolateral views (arrow points at distinctive dorsal process; asterisk marks dorsal elongation of male palpal tarsus). 31. Male chelicerae, frontal view. 32-33. Cleared female genitalia, ventral and dorsal views. Abbreviations: $\mathrm{a}=$ appendix; $\mathrm{b}=$ genital bulb; $\mathrm{e}=$ embolus; $\mathrm{p}=$ procursus; $\mathrm{u}=$ uncus. Scale lines: $0.3 \mathrm{~mm}(31) ; 0.5 \mathrm{~mm}(29-30,32-33)$. 
Chelicerae. As in Fig. 31, with pair of frontal apophyses provided with two modified hairs each and rounded lateral processes.

PALPS. As in Figs 29-30; coxa unmodified; trochanter with retrolatero-ventral apophysis; femur with small retrolateral apophysis proximally; tibia very large; tarsus with dorsal elongation carrying subdistal tarsal organ; procursus with prominent ventral 'knee', with distinctive heavily sclerotized dorsal process distally (arrow in Fig. 30); bulb oval, with distinctive uncus and appendix; weakly sclerotized embolus with subdistal fringed side branch (hidden by appendix in Fig. 29).

LEGS. Without spines and curved hairs; few vertical hairs; retrolateral trichobothrium on tibia 1 at 5\%; prolateral trichobothrium absent on tibia 1, present on other tibiae; tarsus 1 with $\sim 20$ pseudosegments (only distally $\sim 15$ fairly distinct).

Male (variation)

Tibia 1 in 2 other males: 6.1, 7.3.

\section{Female}

In general similar to male (Fig. 8), but without stronger hairs behind PME; sternum mostly dark with some small light marks; eye triads closer together than in male (PME-PME distance: $185 \mu \mathrm{m}$ ). Tibia 1 in 3 females: 5.8, 5.9, 6.1. Epigynum weakly sclerotized whitish plate (Fig. 90), anterior internal arch visible through cuticle, posterior margin laterally slightly more sclerotized; with median 'knob' (Figs 32, 90-91); internal genitalia as in Figs 33 and 92.

\section{Natural history}

All Pulau Ubin specimens were found in a highly degraded patch of forest near park headquarters, while no specimen was found in a well preserved forest about $3.3 \mathrm{~km} \mathrm{WNW}$. Most specimens were collected by beating of branches, but some were observed in their flat resting position on the leaves.

\section{Distribution}

Known from two localities in Singapore and Gaya Island (Sabah) respectively (Fig. 17).

Pholcus sabah Huber, 2011

Figs 9-10

Pholcus sabah Huber, 2011: 133, figs 497-498, 537-541 (ð̊ㅇ).

\section{Diagnosis}

Easily distinguished from putatively closest known relatives (other species in the halabala core group) by 'double' uncus and large rounded rather than pointed flap dorsally on procursus (figs 537, 538 in Huber 2011) and by large lateral structures in female internal genitalia (fig. 541 in Huber 2011).

\section{New material examined}

MALAYSIA-BORNEO: 1 ð, ZFMK (Ar 15012), Sabah, Mt Kinabalu, Poring Hot Springs (type locality), forest near beginning of Kipungit Trail $\left(6.048^{\circ} \mathrm{N}, 116.706^{\circ} \mathrm{E}\right), 450 \mathrm{~m}$ a.s.l., on underside of leaf, 7 Aug. 2014 (B.A. Huber, S.B. Huber); 1 ðૈ, RMNH, Poring Hot Springs, 28-31 Mar. 1998 (C.L. DeelemanReinhold, P. Zborowski); 1 ㄱ, 2 우, 2 juvs, ZFMK (Ar 15013), Sepilok, Rainforest Discovery Centre, forest along Pitta Trail (5.875-5.878 $\left.\mathrm{N}, 117.937-117.942^{\circ} \mathrm{E}\right), 30 \mathrm{~m}$ a.s.l., on undersides of leaves, 9 Aug. 2014 (B.A. Huber, S.B. Huber); 1 \& , 5 juvs, in absolute ethanol, ZFMK (Bor 173), same data. 


\section{Note}

The color dimorphism observed among females from Poring in the original description also occurs among males: while the single male from Sepilok has the 'usual' pattern of two V-marks (Fig. 10), the newly collected male from Poring has a large black mark covering most of the carapace posteriorly (Fig. 9). This latter pattern also occurs in one of the three females from Sepilok. In the male it is associated with a slightly darker brown sternum that is only medially and anteriorly light; in the female it is associated with a black sternum. Tibia 1 in two males: 7.1, 8.4; in two females: 7.1, 7.3.

\section{Natural history}

Most new specimens were collected relatively close to the ground (approximately $50 \mathrm{~cm}$ above the

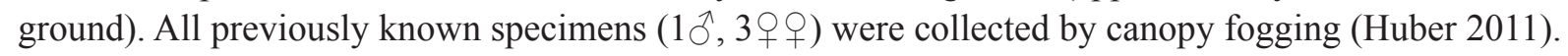

\section{Distribution}

Known from two localities in northeastern Borneo (Fig. 17).

Pholcus lintang Huber, sp. nov. urn:Isid:zoobank.org:act:2AB6CE0F-8B36-4D8F-B1ED-9DFEBB5637DE

Figs 11-12, 34-38, 93-95

\section{Diagnosis}

Easily distinguished from putatively closest known relatives (other species in the halabala core group) by morphology of male palps (Figs 34-35; procursus with rather pointed dorsal flap and without ventrodistal sclerotized process; simple beak-shaped uncus and simple curved appendix) and by female internal genitalia (Figs 37-38; large rounded pore plates close to each other; small lateral structures).

\section{Etymology}

The species name is derived from the type locality; noun in apposition.

\section{Type material}

MALAYSIA-BORNEO: holotype, đ̃, ZFMK (Ar 15014), Sarawak, Bako National Park, along Lintang Trail (1.713-1.722 $2^{\circ}$, 110.447-110.457 ${ }^{\circ}$ E), 10-130 m a.s.l., 11 Jul. 2014 (B.A. Huber, S.B. Huber).

\section{Other material examined}

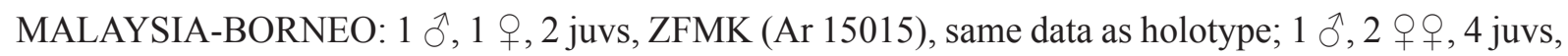
in absolute ethanol, ZFMK (Bor 192), same data.

\section{Assigned tentatively}

MALAYSIA-BORNEO: 1 q, 4 juvs, in absolute ethanol, ZFMK (Bor 221), Sarawak, Kubah National Park, along Main Trail (1.611 ${ }^{\circ}$ N, 110.191-110.195 ${ }^{\circ}$ E), 160-200 m a.s.l., 13 Jul. 2014 (B.A. Huber, S.B. Huber); 1 , in absolute ethanol, ZFMK (Bor 224), Niah Cave National Park, forest near headquarters $\left(3.820^{\circ} \mathrm{N}, 113.763^{\circ} \mathrm{E}\right), 40 \mathrm{~m}$ a.s.l., night collecting, 28 Jul. 2014 (B.A. Huber, S.B. Huber).

\section{Description}

Male (holotype)

Measurements. Total body length 3.5, carapace width 0.95. Leg 1: $27.6(6.6+0.4+6.6+12.5+1.5)$, tibia 2: 4.3, tibia 3: 2.6, tibia 4: 3.7; tibia 1 L/d: 79. Distance PME-PME $290 \mu \mathrm{m}$, diameter PME $95 \mu \mathrm{m}$, distance PME-ALE $35 \mu \mathrm{m}$; distance AME-AME $55 \mu \mathrm{m}$; diameter AME $50 \mu \mathrm{m}$. 
COLOR. Carapace pale ochre-whitish with brown pattern of radiating marks posteriorly; ocular area and clypeus not darkened; sternum whitish with dark lateral margins; legs pale whitish with brown patellae and tibia-metatarsus joints; abdomen pale gray with black and white marks dorsally and laterally, monochromous ventrally.

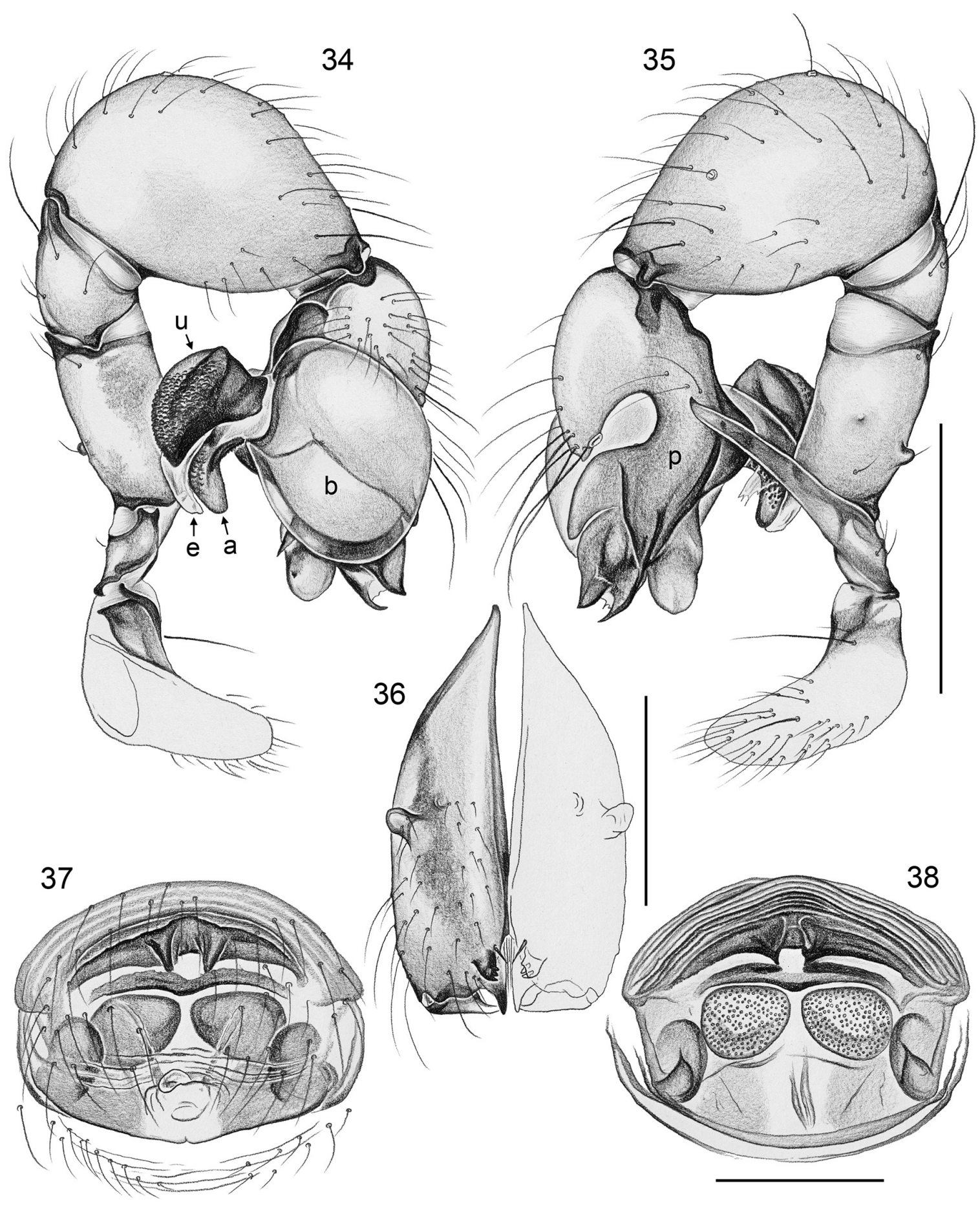

Figs 34-38. Pholcus lintang Huber, sp. nov., ZFMK Ar 15015. 34-35. Left male palp, prolateral and retrolateral views. 36. Male chelicerae, frontal view. 37-38. Cleared female genitalia, ventral and dorsal views. Abbreviations: $\mathrm{a}=$ appendix; $\mathrm{b}=$ genital $\mathrm{bul} b ; \mathrm{e}=$ embolus; $\mathrm{p}=$ procursus; $\mathrm{u}=$ uncus. Scale lines: $0.3 \mathrm{~mm}(36-38) ; 0.5 \mathrm{~mm}(34-35)$. 
BoDy. Habitus as in Fig. 11; ocular area raised, with brushes of $\sim 4$ spines on low hump behind each PME; carapace without median furrow; clypeus unmodified; sternum wider than long $(0.66 / 0.50)$, unmodified.

Chelicerae. As in Fig. 36, with pair of frontal apophyses provided with two modified hairs each, rounded lateral processes, and indistinct small frontal proximal humps.

PALPS. As in Figs 34-35; coxa unmodified; trochanter with retrolatero-ventral apophysis; femur widened proximally ventrally, with small retrolatero-dorsal apophysis proximally and low retrolateral hump; tibia very large; tarsus with conical dorsal elongation carrying subdistal tarsal organ; procursus with prominent ventral 'knee', with distinctive flat dorsal process and distal elements; bulb oval, with distinctive uncus and appendix; weakly sclerotized embolus with subdistal fringed side branch.

LEGS. Without spines and curved hairs; few vertical hairs; retrolateral trichobothrium on tibia 1 at $6 \%$; prolateral trichobothrium absent on tibia 1, present on other tibiae; tarsus 1 pseudosegments very indistinct, only distally $\sim 10$ poorly visible in dissecting microscope.

Male (variation)

Tibia 1 in other male: 7.0; this male with slightly more pigment, clypeus with large light brown mark.

\section{Female}

In general similar to male (Fig. 12) but without spines behind PME and eye triads closer together than in male (PME-PME distance: $230 \mu \mathrm{m}$ ). Tibia 1 in 1 female: 6.2. Epigynum mostly weakly sclerotized except for posterior area (Fig. 93); with median 'knob' (Figs 37, 94); internal genitalia as in Figs 38 and 95, with roundish pore plates close to each other. Females from Kubah National Park and Niah Cave National Park are assigned tentatively because females in this species group are not easily distinguished externally and no males are available from these localities.

\section{Natural history}

At Bako, this species was found on the plateau, in the rather low Kerangas forest. At Kubah, most specimens were taken from large leaves of ornamental plants close to the buildings; only one specimen was found in well-preserved forest.

\section{Distribution}

Known from three localities in northern Borneo (Fig. 17; note that specimens from Kubah and Niah are assigned tentatively).

Pholcus erawan Huber, 2011

Figs 13-16, 39-48

Pholcus erawan Huber, 2011: 297-298, figs 1374-1375, 1404-1405, 1466-1470 (ぷ゚).

\section{Diagnosis}

Easily distinguished from putatively closest known relatives (other species in the halabala core group) by absence of dorsal flap on procursus, by long whitish process of male palpal tarsus (fig. 1467 in Huber 2011), by unique shapes of bulbal processes (fig. 1644 in Huber 2011), and by much longer than wide female internal genitalia and small oval pore plates (fig. 1470 in Huber 2011).

\section{New material examined}

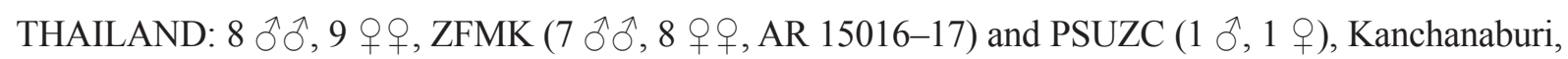

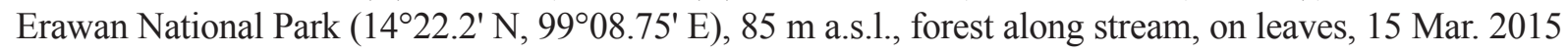



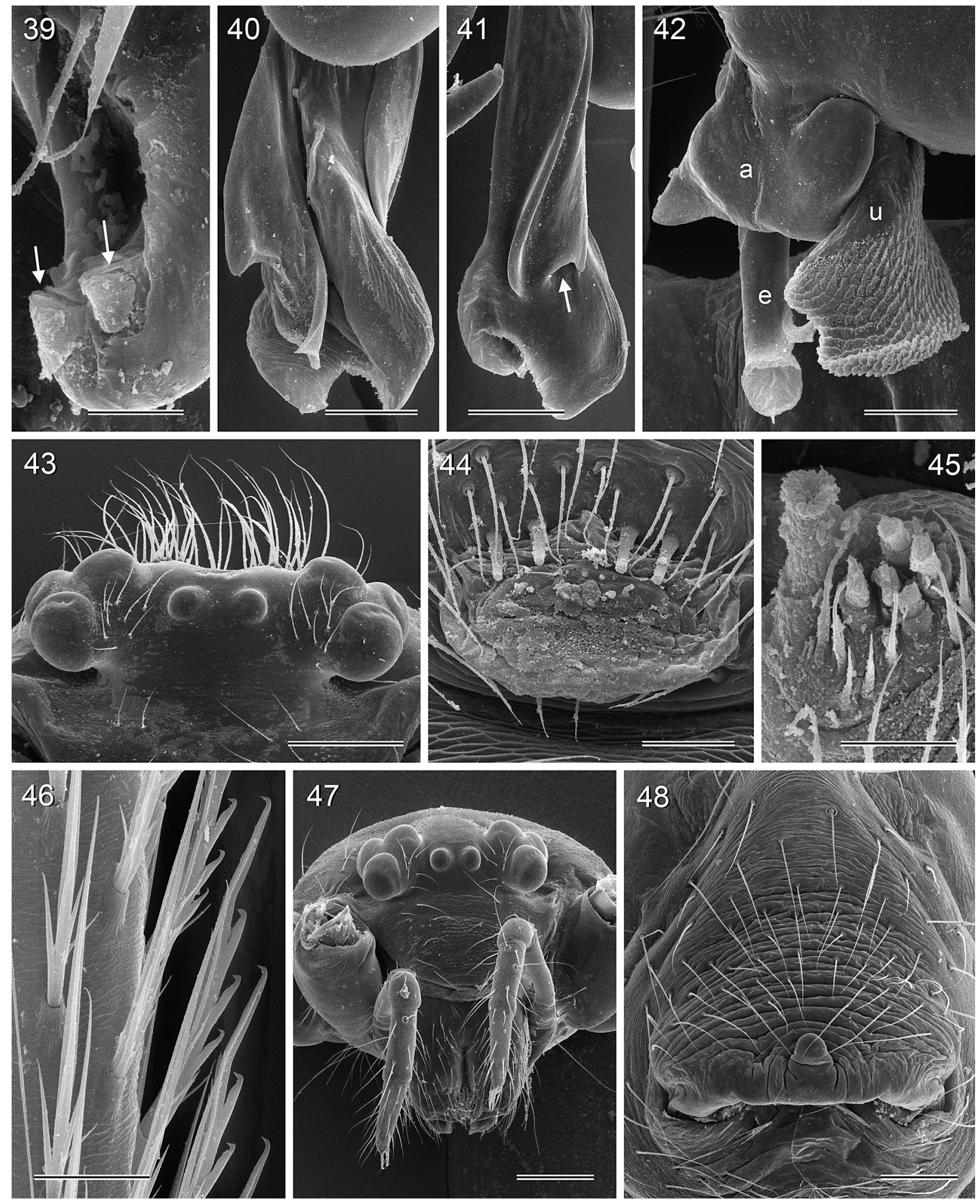

Figs 39-48. Pholcus erawan Huber, 2011, ZFMK Ar 15016-17. 39. Male distal cheliceral apophysis (arrows point at modified hairs). 40. Left procursus, prolateral view. 41. Right procursus, retrolatero-dorsal view (arrow points at distal pocket). 42. Left bulbal processes, distal view. 43. Male ocular area, frontal view. 44. Male gonopore. 45. Female ALS. 46. Comb-hairs on male tarsus 4. 47. Female prosoma, frontal view. 48. Epigynum, ventral view. Abbreviations: $\mathrm{a}=$ appendix; $\mathrm{e}=$ embolus; $\mathrm{u}=$ uncus. Scale lines: $10 \mu \mathrm{m}$ (39); $20 \mu \mathrm{m}$ (45-46); $40 \mu \mathrm{m}$ (44); $60 \mu \mathrm{m}$ (42); $80 \mu \mathrm{m}$ (40); $100 \mu \mathrm{m}(41,48) ; 200 \mu \mathrm{m}(43,47)$. 
(B.A. Huber, B. Petcharad); $2 \hat{\jmath}, 7$ $\rho$ q , in absolute ethanol, ZFMK (Mal 378), same data; $1 \hat{\jmath}, 1$ q, ZFMK

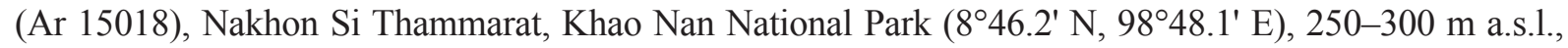
on leaves in forest, 9 Mar. 2015 (B.A. Huber, B. Petcharad); 1 ô, ZFMK (Ar 15019), same data, collected penultimate, adult on 11 Mar. 2015; 3 juvs, in absolute ethanol, ZFMK (Mal 345), same data; $3 \hat{\jmath} \widehat{\partial}, 3$ $q$ q ,

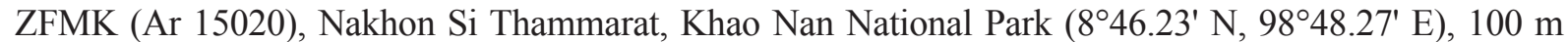
a.s.l., on palm leaves near park buildings, 9 Mar. 2015 (B.A. Huber, B. Petcharad); 1 ठ̊, ZFMK (Ar 15021),

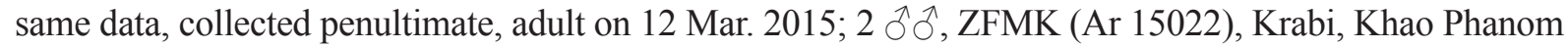
Bencha National Park, trails near headquarters ( $\left.8^{\circ} 14.1^{\prime} \mathrm{N}, 98^{\circ} 55.1^{\prime} \mathrm{E}\right), 150-300 \mathrm{~m}$ a.s.l., on leaves, 8 Mar. 2015 (B.A. Huber, B. Petcharad); 4 우, 4 juvs, in absolute ethanol, ZFMK (Mal 340), same data.

MALAYSIA: $2 \widehat{\diamond}, 5$ 우, ZFMK (Ar 15023), Kedah, Gunung Jerai, forest near Sri Perigi Waterfall $\left(5^{\circ} 48.3^{\prime} \mathrm{N}, 100^{\circ} 24.6^{\prime} \mathrm{E}\right), 100-200 \mathrm{~m}$ a.s.l., on leaves, $27 \mathrm{Feb} .2015$ (B.A. Huber); 1 \&, 6 juvs, in absolute ethanol, ZFMK (Mal 291), same data; 4 $\widehat{\partial} \hat{\jmath}, 3$ 우, 1 juv., ZFMK (Ar 15024), Pulau Pinang, Penang National Park near Teluk Bahang ( $\left.5^{\circ} 27.7^{\prime} \mathrm{N}, 100^{\circ} 12.1^{\prime} \mathrm{E}\right), 10-50 \mathrm{~m}$ a.s.l., on leaves, 28 Feb. 2015 (B.A.

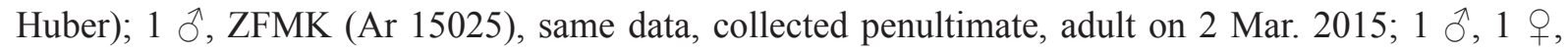
1 juv., in absolute ethanol, ZFMK (Mal 296), same data.

\section{Description - amendments}

Carapace pattern slightly variable, ranging from two separate V-marks (Fig. 15) to medially fused V-marks to almost completely fused single posterior mark (Fig. 14). Females and juveniles with more delicate V-marks. Sternum coloration also slightly variable, from almost monochromous whitish to small black posterior marks (males) and larger black posterior marks (females). Tibia 1 in 21 males: 6.3-8.1 (mean 7.1); in 20 females: 5.8-6.7 (mean 6.3). In most males, except those from the type locality (Erawan), the ventro-distal sclerite of the procursus is slightly more pointed than illustrated in Huber 2011 (fig. 1467). Male ocular area with dense brush of stronger hairs, but without spines (Fig. 43); tarsus 4 comb-hairs of the simplified Pholcus-type (cf. Huber \& Fleckenstein 2008), with three lateral tines (Fig. 46); procursus with retrolateral distal pocket (Fig. 41); distal male cheliceral apophyses with two cone-shaped teeth (modified hairs) each (Fig. 39); gonopore with four epiandrous spigots (Fig. 44); ALS with one widened, one pointed, and six smaller cylindrically shaped spigots of varying sizes (Fig. 45; pointed spigot damaged in this spinneret).

\section{Natural history}

As noted above, Ph. erawan was sometimes found at the same localities as Ph. halabala but on monocot rather than dicot leaves. Only at Erawan, this species seemed to occur on all kinds of leaves, preferably (but not only) large ones. At Khao Nan, Ph. erawan was found on palm leaves both in the forest and in the garden near the park buildings. At Penang, specimens were found both on green leaves and on dead brown leaves still attached to the plant. Small silk tufts were observed in the webs at most localities. At night (at Erawan), spiders were observed moving among the vegetation.

\section{Distribution}

Widely distributed on the Malay Peninsula, reaching northern Laos (Fig. 17).

Pholcus kuhapimuk Huber, sp. nov. urn:1sid:zoobank.org:act:851588EA-3FD5-4800-9F4D-33BAE6E2E0F9

Figs 49-51, 58-62, 96-98

\section{Diagnosis}

Easily distinguished from most similar known relative ( $P h$. khaolek sp. nov.) by morphology of male palps (Figs 58-59; shapes of male palpal tarsus and procursus tip, small uncus, slender appendix) and by 
female internal genitalia (Figs 61-62; absence of median triangular sclerite). From other putatively close relatives also by combination of pale coloration (Figs 49-51), shape of male palpal trochanter apophysis (curved, proximally wide, distally pointed; Fig. 59), and small round pore plates far apart (Fig. 62).

\section{Etymology}

The species name is derived from the type locality; noun in apposition.

\section{Type material}

THAILAND: holotype, ${ }^{\lambda}$, ZFMK (Ar 15026), Yala, Wat Kuhapimuk (6³1.7’ N, 101¹3.5' E), $40 \mathrm{~m}$ a.s.l., on wall in cave entry area, 4 Mar. 2015 (B.A. Huber, B. Petcharad).
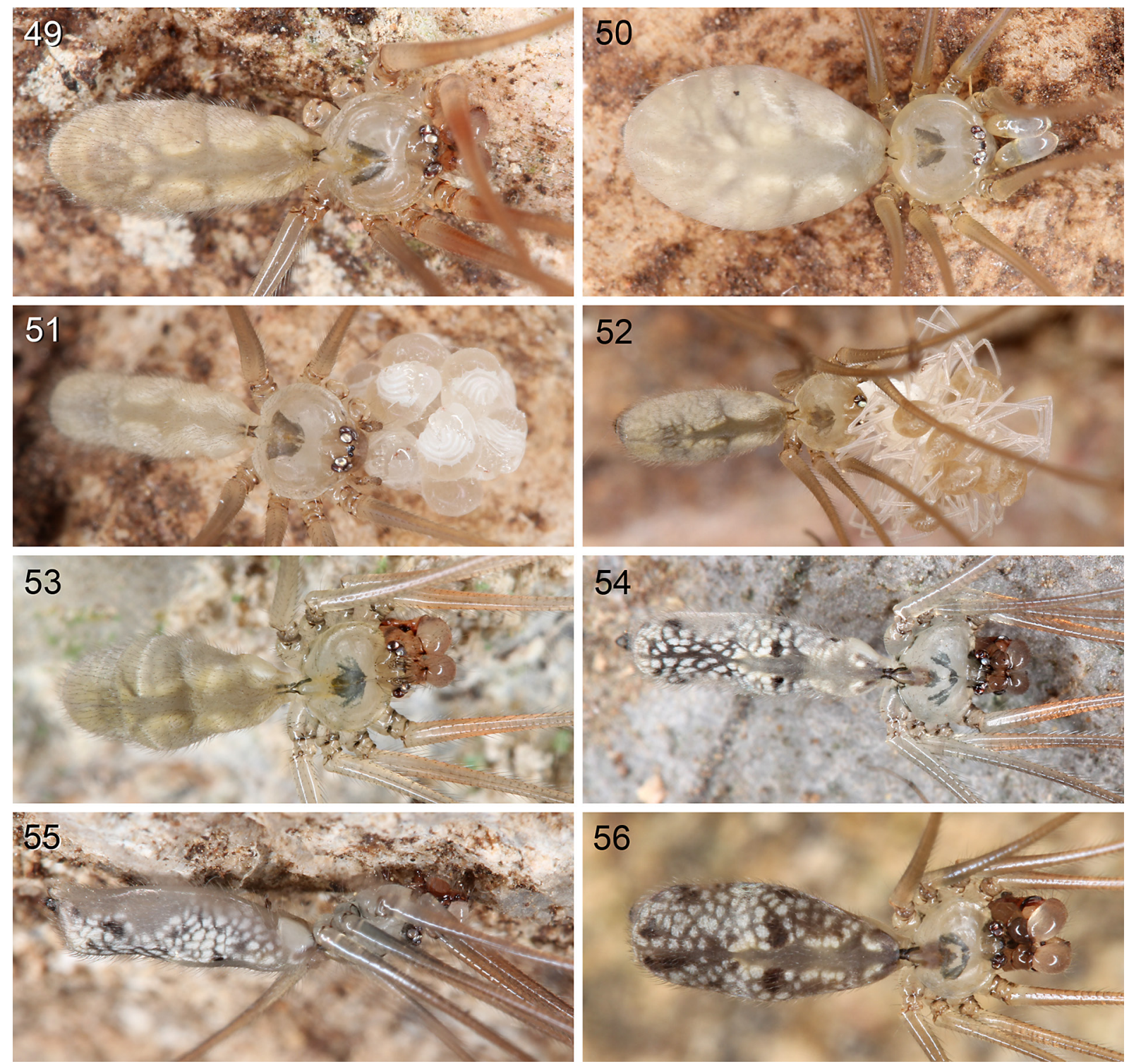

Figs 49-56. Live specimens, Pholcus kuhapimuk Huber, sp. nov. (49-51), Ph. khaolek Huber, sp. nov. (52-53), and Ph. sudhami Huber, 2011 (54-56). 49-51. $\hat{\sigma}$, penultimate instar $\hat{\partial}$, and $q$ with egg-sac from Wat Kuhapimuk, Thailand. 52-53. + with spiderlings and $\widehat{\jmath}$ from Khao Lek, Thailand. 54-55. $\curvearrowright$ from Tham Phraya Nakhon, Thailand. 56. $\widehat{\diamond}$ from Erawan, Thailand. 


\section{Other material examined}

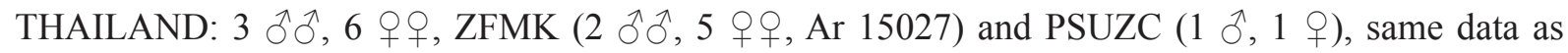
holotype; 1 $\hat{0}, 4$ 우, 4 juvs, in absolute ethanol, ZFMK (Mal 324), same data.

\section{Assigned tentatively}

THAILAND: 1 \&, 2 juvs, in absolute ethanol, ZFMK (Mal 329), Satun, Thaleban National Park (6 $6^{\circ} 43.58^{\prime}$ N, $100^{\circ} 09.74^{\prime}$ E), at rocks near cave entrance, 100 m a.s.1., 5 Mar. 2015 (B.A. Huber, B. Petcharad).

\section{Description}

Male (holotype)

Measurements. Total body length 5.0, carapace width 1.4. Leg 1: $53.3(12.9+0.5+12.9+25.0+2.0)$, tibia 2: 8.6, tibia 3: 5.4, tibia 4: 7.3; tibia $1 \mathrm{~L} / \mathrm{d}$ : 98. Distance PME-PME $265 \mu \mathrm{m}$, diameter PME $115 \mu \mathrm{m}$, distance PME-ALE $\sim 35 \mu \mathrm{m}$; distance AME-AME $35 \mu \mathrm{m}$; diameter AME $60 \mu \mathrm{m}$.

CoLor. Carapace pale ochre-grey with pair of brown marks posteriorly; ocular area slightly darker, clypeus not darkened; sternum pale grey with narrow dark margins; legs pale ochre-yellow with dark brown patellae and tibia-metatarsus joints; abdomen monochromous pale gray.

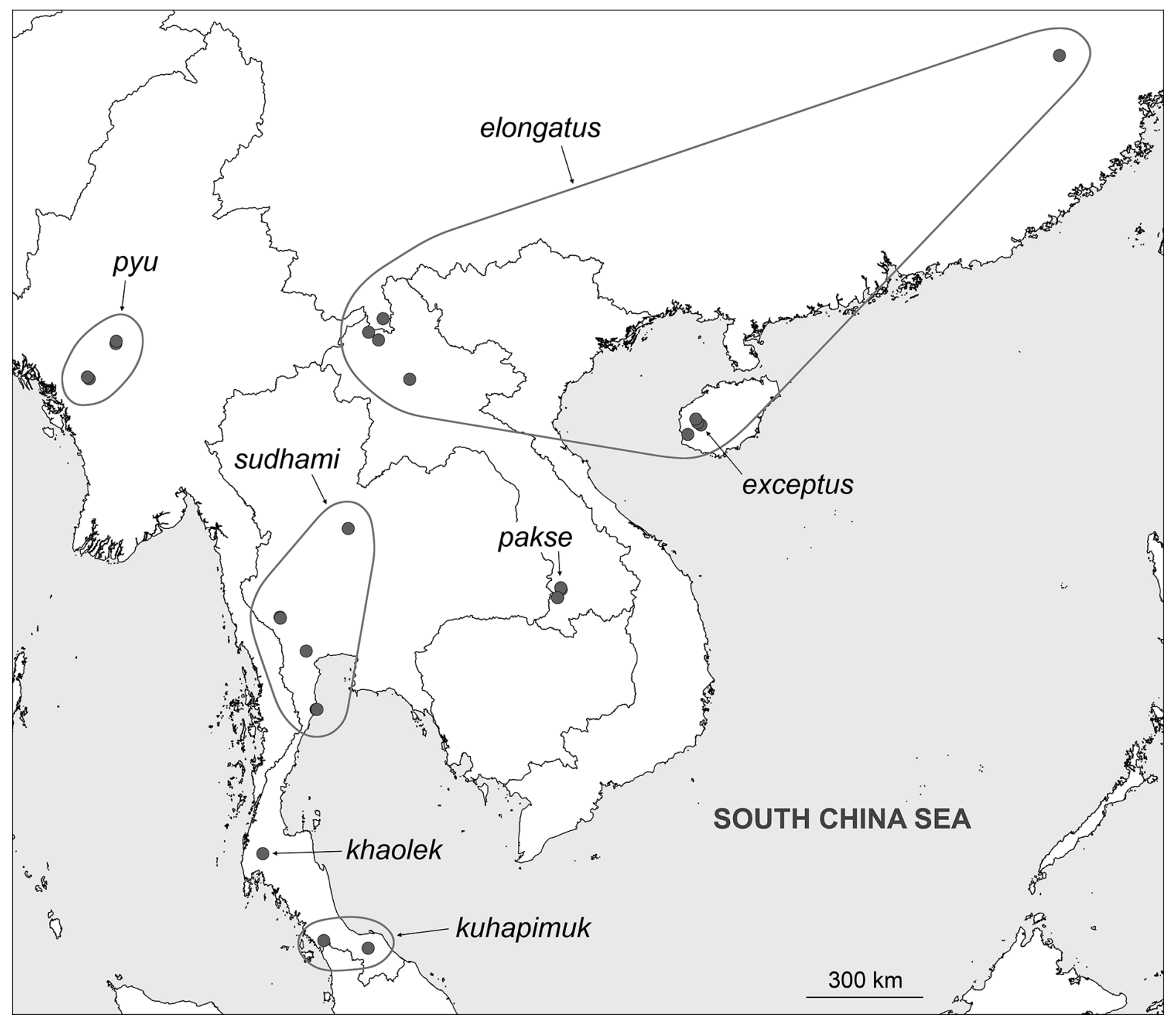

Fig. 57. Known distributions of species tentatively assigned to the Pholcus halabala species group. 
BoDy. Habitus as in Fig. 49; ocular area slightly raised, with slightly stronger hairs behind each PME; carapace without median furrow; clypeus unmodified; sternum wider than long (1.00/0.67), unmodified.

Chelicerae. As in Fig. 60, with pair of distal frontal apophyses provided with one or two modified hairs each, pair of rounded lateral processes, and pair of small indistinct proximal frontal humps.

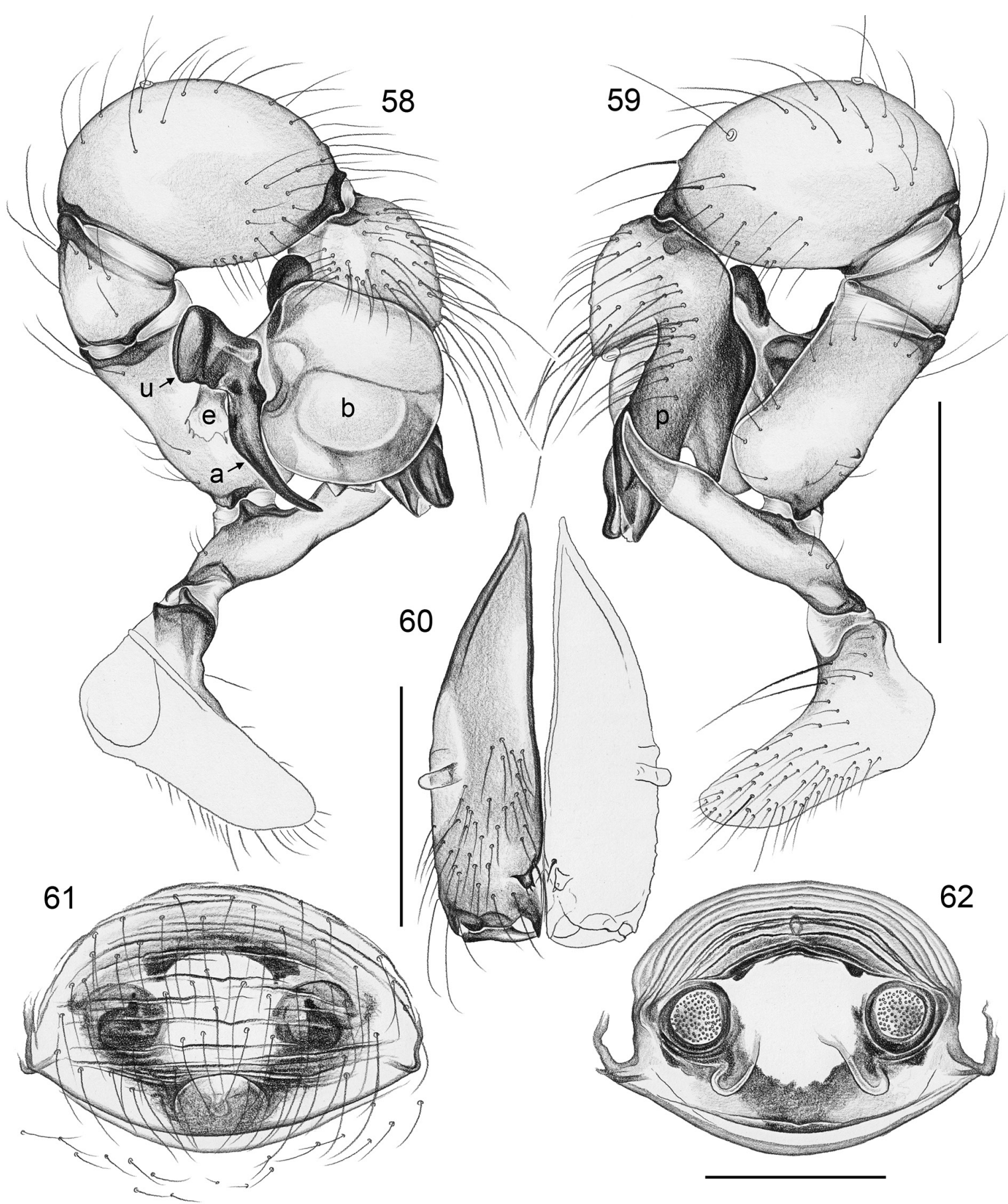

Figs 58-62. Pholcus kuhapimuk Huber, sp. nov., ZFMK Ar 15027. 58-59. Left male palp, prolateral and retrolateral views. 60. Male chelicerae, frontal view. 61-62. Cleared female genitalia, ventral and dorsal views. Abbreviations: $\mathrm{a}=$ appendix; $\mathrm{b}=$ genital bul $\mathrm{b} ; \mathrm{e}=$ embolus; $\mathrm{p}=$ procursus; $\mathrm{u}=$ uncus. Scale lines: $0.3 \mathrm{~mm}(61-62) ; 0.5 \mathrm{~mm}(58-60)$. 
PaLPS. As in Figs 58-59; coxa unmodified; trochanter with large but weakly sclerotized retrolateroventral apophysis and low retrolateral hump; femur proximally widened on ventral side, with small retrolatero-dorsal apophysis; tarsus with short conical dorsal elongation carrying subdistal tarsal organ; procursus rather simple, ventral 'knee' with distal process; bulb with distinctive small uncus and slender appendix; weakly sclerotized short embolus.

LEgs. Without spines and curved hairs; few vertical hairs; retrolateral trichobothrium on tibia 1 at $6 \%$; prolateral trichobothrium absent on tibia 1, present on other tibiae; tarsus 1 with $>30$ pseudosegments, distally fairly distinct.

Male (variation)

Tibia 1 in 2 other males: 11.1, 12.6 .

\section{Female}

In general similar to male (Fig. 51) but without stronger hairs behind PME; eye triads closer together than in male (PME-PME distance: $185 \mu \mathrm{m}$ ). Tibia 1 in 7 females: 8.1-9.8 (mean 8.7). Epigynum weakly sclerotized bulging area, only posterior margin more strongly sclerotized, apparently without 'knob', or 'knob' hidden below membranous flap (Figs 61, 96-97); internal genitalia as in Figs 62 and 98, with small round pore plates far from each other. The specimens from Thaleban National Park are assigned tentatively because no male specimen is available from this locality.

\section{Natural history}

At both localities, specimens were only found on rocks at the cave entrances but not deeper in the caves. The spiders were extremely cryptic, tightly pressed against the rock surface and barely visible even at close distance.

\section{Distribution}

Known from two localities in southern Thailand only (Fig. 57; specimens from Thaleban National Park assigned tentatively).

\section{Pholcus khaolek Huber, sp. nov. urn:1sid:zoobank.org:act:2A1CAF47-9EB4-480C-8C83-DFB0162AF617}

Figs 52-53, 63-78, 99-101

\section{Diagnosis}

Easily distinguished from most similar known relative (Ph. kuhapimuk sp. nov.) by morphology of male palps (Figs 63-64; shapes of male palpal tarsus and procursus tip, larger uncus, complex appendix with retrolateral process) and by female internal genitalia (Figs 66-67; distinctive median triangular sclerite). From other close relatives also by combination of pale coloration (Figs 52-53), shape of male palpal trochanter apophysis (curved, proximally wide, distally pointed; Fig. 64), and shape and position of pore plates (Fig. 67).

\section{Etymology}

The species name is derived from the type locality; noun in apposition.

\section{Type material}

THAILAND: holotype, $\widehat{\partial}$, ZFMK (Ar 15028), Nakhon Si Thammarat, Khao Nan National Park, Tham Khao Lek ( $\left.8^{\circ} 46.09^{\prime} \mathrm{N}, 98^{\circ} 43.68^{\prime} \mathrm{E}\right), 95$ m a.s.1., on rock walls around cave, 10 Mar. 2015 (B.A. Huber, B. Petcharad). 


\section{Other material examined}

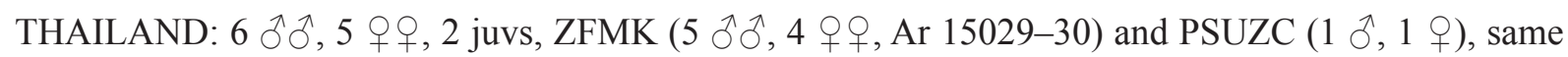
data as holotype; 1 ô, 2 q $q, 3$ juvs, in absolute ethanol, ZFMK (Mal 350), same data.

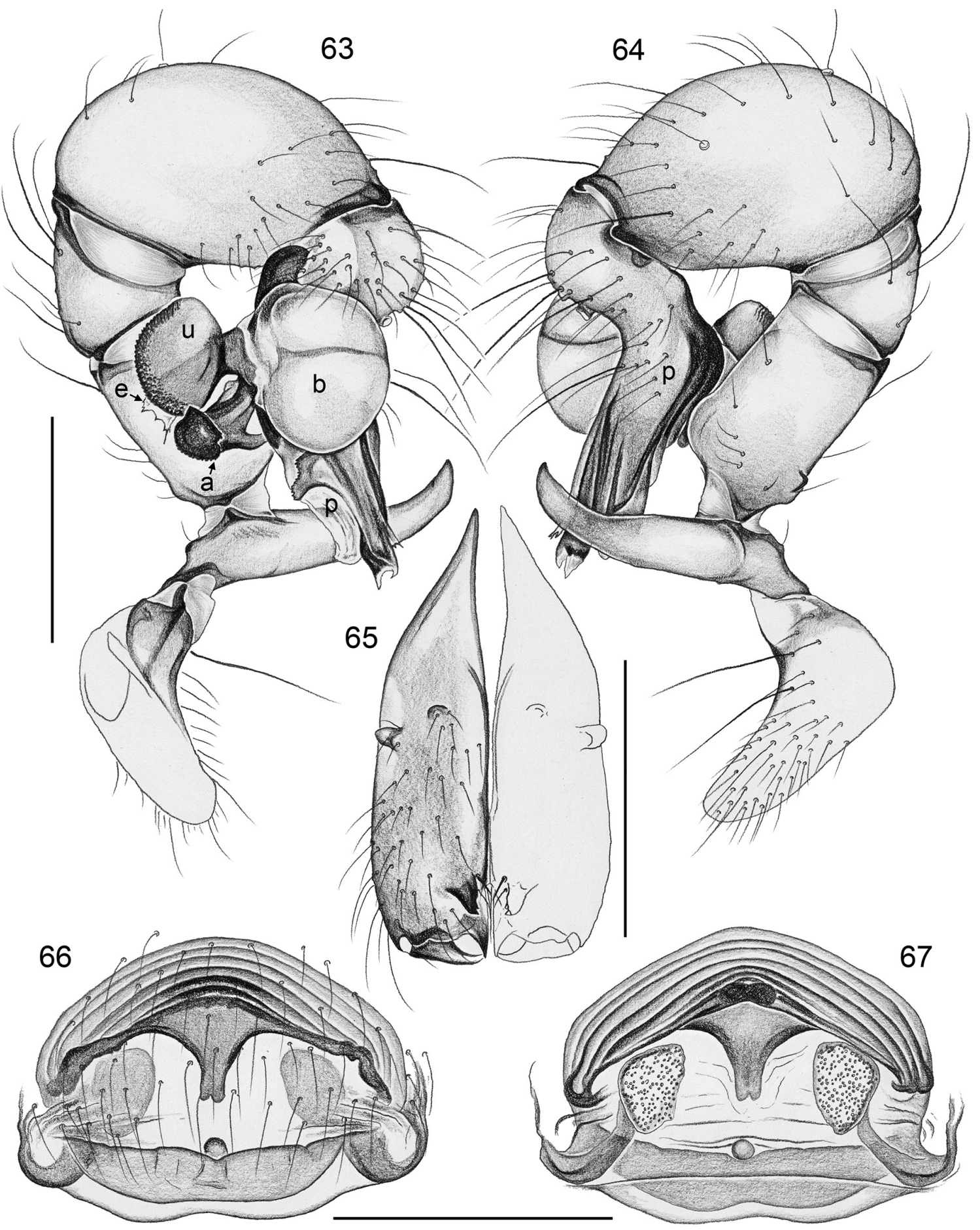

Figs 63-67. Pholcus khaolek Huber, sp. nov., ZFMK Ar 15029-30. 63-64. Left male palp, prolateral and retrolateral views. 65. Male chelicerae, frontal view. 66-67. Cleared female genitalia, ventral and dorsal views. Abbreviations: $\mathrm{a}=$ appendix; $\mathrm{b}=$ genital bulb; $\mathrm{e}=$ embolus; $\mathrm{p}=$ procursus; $\mathrm{u}=$ uncus. Scale lines: $0.5 \mathrm{~mm}$. 

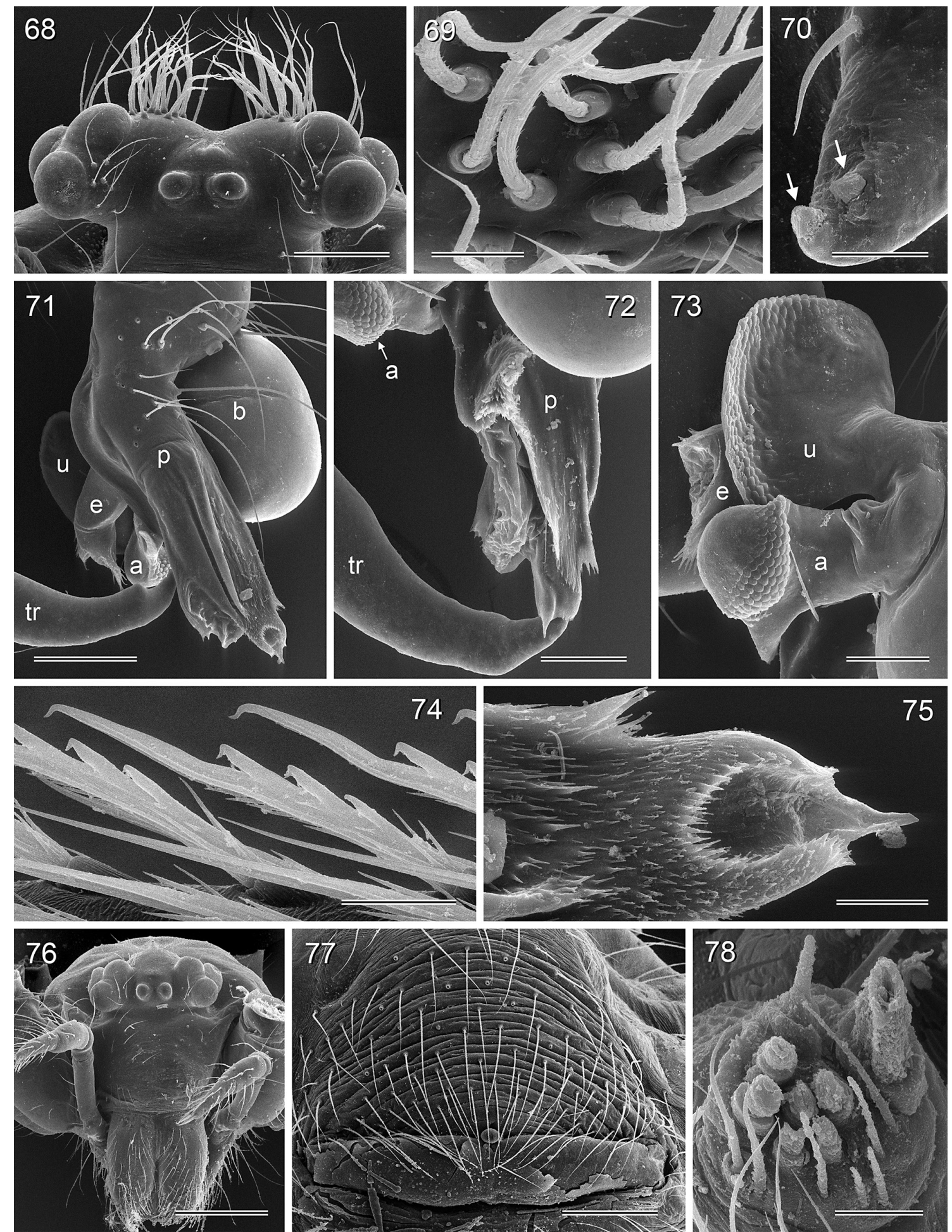

Figs 68-78. Pholcus khaolek Huber, sp. nov., ZFMK Ar 15029-30. 68. Male ocular area, frontal view. 69. Modified hairs between male eye triads. 70. Male distal cheliceral apophysis (arrows point at modified hairs). 71. Right procursus, retrolateral view. 72. Left procursus, prolateral view. 73. Left bulbal processes, prolateral view. 74. Comb-hairs on male tarsus 4. 75. Tip of right procursus, retrolateral view. 76. Female prosoma, frontal view. 77. Epigynum, ventral view. 78. Male ALS. Abbreviations: $\mathrm{a}=$ appendix $; \mathrm{b}=$ genital bulb; $\mathrm{e}=$ embolus; $\mathrm{p}=$ procursus; $\mathrm{tr}=$ trochanter; $\mathrm{u}=$ uncus. Scale lines: $20 \mu \mathrm{m}$ (70, 74, 78); $30 \mu \mathrm{m}(69,75) ; 80 \mu \mathrm{m}(73) ; 100 \mu \mathrm{m}(72) ; 200 \mu \mathrm{m}(68,71,77) ; 400 \mu \mathrm{m}(76)$. 


\section{Description}

Male (holotype)

Measurements. Total body length 4.6, carapace width 1.3. Leg 1: $48.6(11.6+0.6+11.7+22.8+1.9)$, tibia 2: 7.9, tibia 3: 4.5, tibia 4: 6.3; tibia 1 L/d: 95. Distance PME-PME $340 \mu \mathrm{m}$, diameter PME $125 \mu \mathrm{m}$, distance PME-ALE $\sim 35 \mu \mathrm{m}$; distance AME-AME $50 \mu \mathrm{m}$; diameter AME $55 \mu \mathrm{m}$.

CoLor. Carapace pale ochre-yellow with pair of light brown marks posteriorly; ocular area and clypeus not darkened; sternum light brown with lighter marks and dark lateral margins; legs ochre-yellow with dark brown patellae and tibia-metatarsus joints; abdomen monochromous ochre-gray.

Body. Habitus as in Fig. 53; ocular area slightly raised, with brushes of stronger hairs behind each PME (Figs 68-69); carapace without median furrow; clypeus unmodified; sternum wider than long (0.84/0.52), unmodified. ALS with one widened, one pointed, and six smaller cylindrically shaped spigots of varying sizes (Fig. 78).

Chelicerae. As in Fig. 65, with pair of distal frontal apophyses provided with two to three modified (cone-shaped) hairs each (Fig. 70), pair of rounded lateral processes, and pair of small indistinct proximal frontal humps.

PALPS. As in Figs 63-64; coxa unmodified; trochanter with large retrolatero-ventral apophysis; femur proximally widened on ventral side, with small retrolatero-dorsal apophysis; tarsus without dorsal elongation; procursus rather simple (Figs 71-72), with prolateral weakly sclerotized process and transparent membranous structures; procursus tip as in Fig. 75; bulb with distinctive uncus and appendix with retrolateral process (Fig. 73); weakly sclerotized short embolus.

LEGS. Without spines and curved hairs; few vertical hairs; retrolateral trichobothrium on tibia 1 at $6 \%$; prolateral trichobothrium absent on tibia 1, present on other tibiae; tarsus 1 with $>30$ pseudosegments, distally fairly distinct. Tarsus 4 comb-hairs as in Fig. 71.

Male (variation)

Tibia 1 in 5 other males: 10.1-12.8 (mean 11.7). Some males with white marks on abdomen.

\section{Female}

In general similar to male (Fig. 52) but without stronger hairs behind PME; eye triads closer together than in male (PME-PME distance: $220 \mu \mathrm{m}$ ). Tibia 1 in 5 females: 8.7-10.1 (mean 9.3). Epigynum weakly sclerotized bulging area, only posterior area more strongly sclerotized, with small but distinct 'knob' (Figs 66, 77, 99-100); internal genitalia as in Figs 67 and 101, with anterior arch and distinctive triangular sclerite visible through cuticle.

\section{Natural history}

This species was abundant at the type locality on vertical and slightly overhanging smooth rocks. Specimens were observed tightly pressed against the rock surface, in some cases with a small domed web nearby. When disturbed, the spiders dropped to the ground.

\section{Distribution}

Known from type locality only (Fig. 57).

Pholcus sudhami Huber, 2011

Figs 54-56, 79-89

Pholcus sudhami Huber, 2011: 300, figs 1380-1382, 1411-1412, 1476-1480 (ð゚). 


\section{Diagnosis}

Easily distinguished from most congeners by male palpal morphology (figs 1476, 1477 in Huber 2011; distinctive procursus with large membranous structure, absence of appendix) and by female genitalia
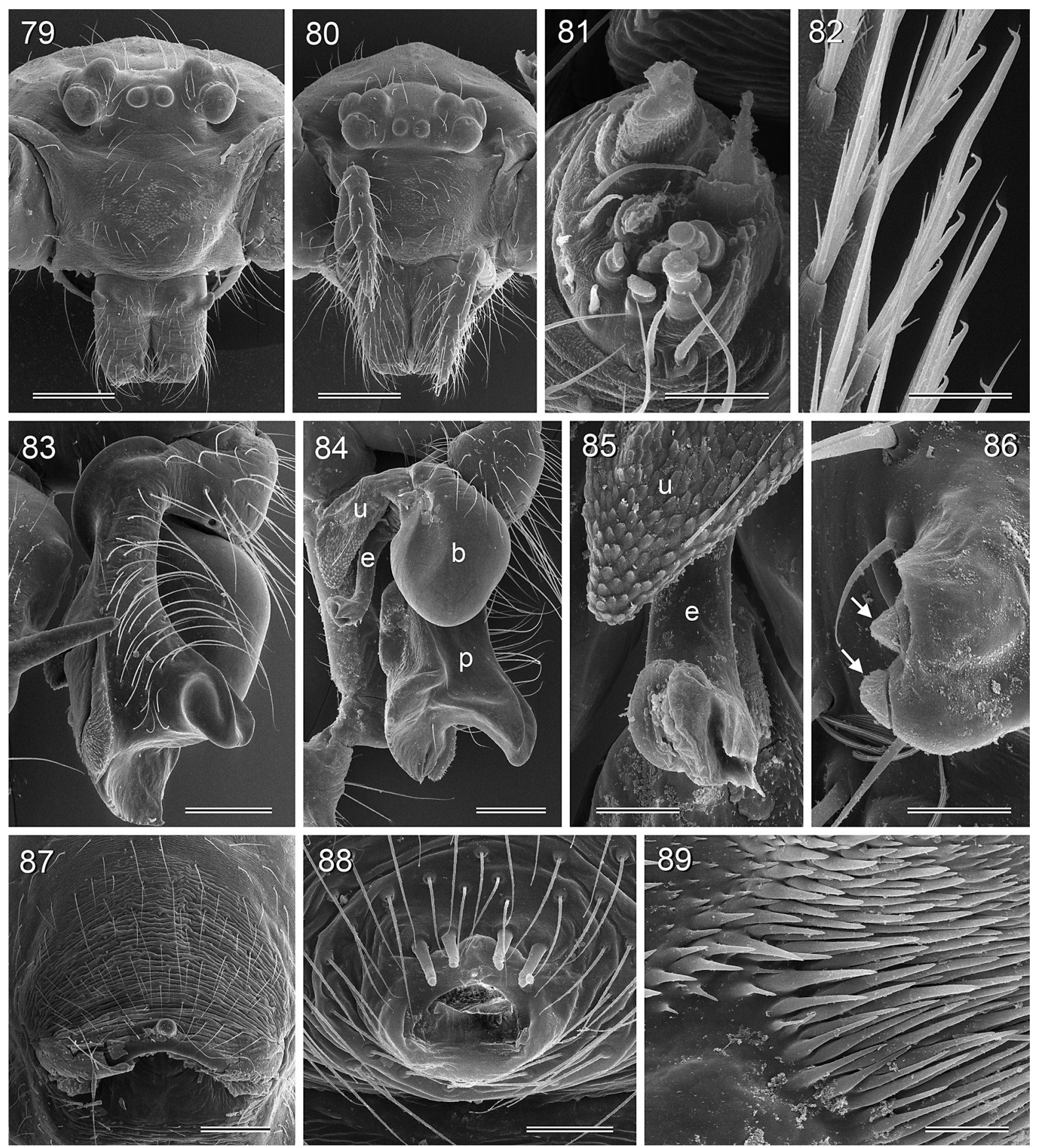

Figs 79-89. Pholcus sudhami Huber, 2011, ZFMK Ar 15031-32. 79-80. Male and female prosomata, frontal views. 81. Female ALS. 82. Comb-hairs on male tarsus 4. 83. Right procursus, retrolateral (slightly distal) view. 84. Left bulb and procursus, prolateral view. 85. Left uncus and embolus, prolateral view. 86. Male distal cheliceral apophysis (arrows point at modified hairs). 87. Epigynum, ventral view. 88. Male gonopore. 89. Pseudotrichia on ventral side of procursus. Abbreviations: $b=$ genital bulb; $\mathrm{e}=$ embolus; $\mathrm{p}=$ procursus; $\mathrm{u}=$ uncus. Scale lines: $20 \mu \mathrm{m}(81-82,86) ; 30 \mu \mathrm{m}(89) ; 50 \mu \mathrm{m}(88) ; 60 \mu \mathrm{m}$ (85); $200 \mu \mathrm{m}(83-84,87) ; 300 \mu \mathrm{m}(79-80)$. 
(figs 1479 and 1480 in Huber 2011; elongate pore plates in lateral position and semicircular internal structures visible through cuticle; very similar to Ph. pakse); from Ph. pakse only by male embolus without spines (compare figs 1476 and 1481 in Huber 2011).
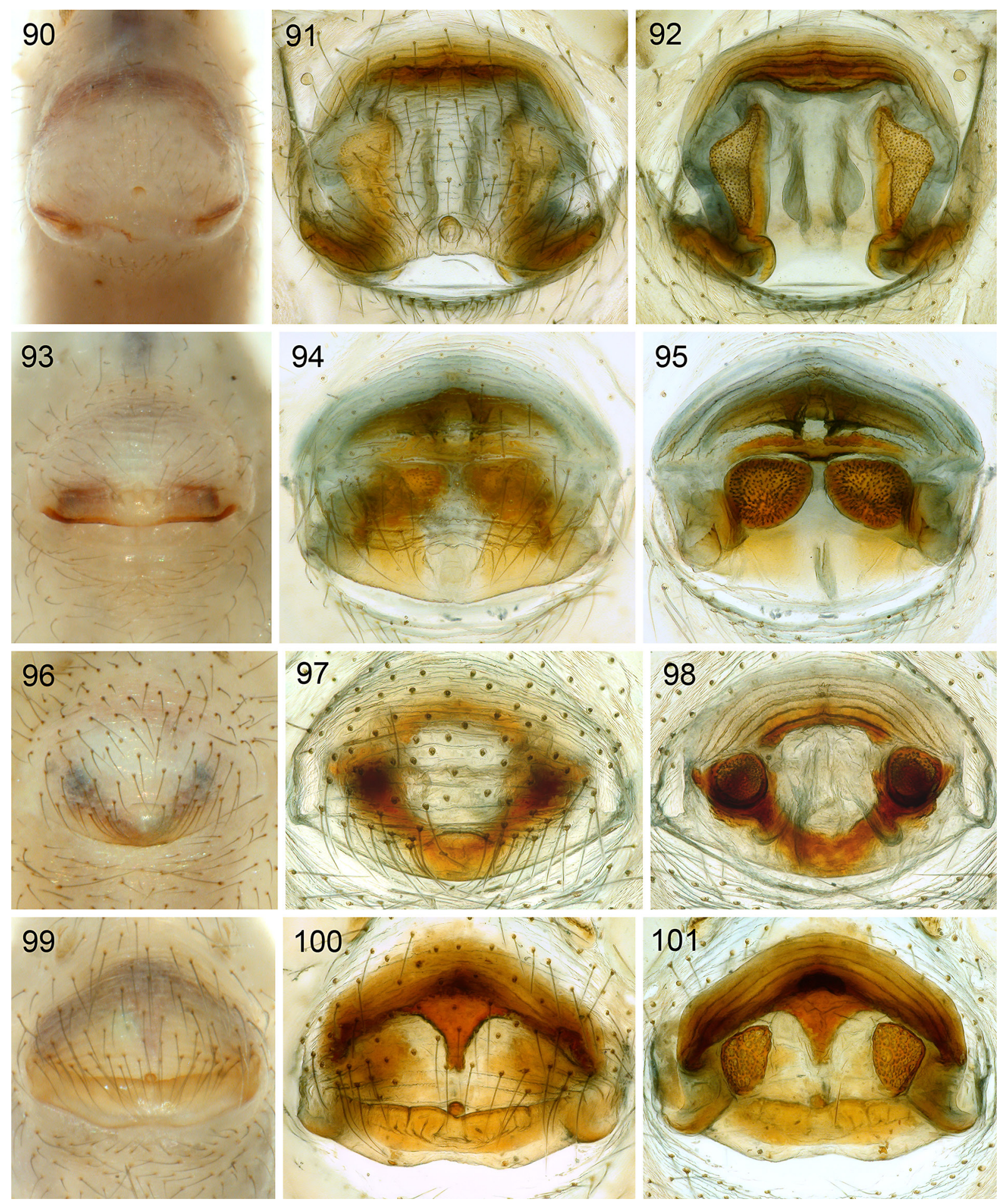

Figs 90-101. Female genitalia, untreated in ventral view, cleared in ventral and dorsal views. 9092. Pholcus ubin Huber, sp. nov. 93-95. Ph. lintang Huber, sp. nov. 96-98. Ph. kuhapimuk Huber, sp. nov. 99-101. Ph. khaolek Huber, sp. nov. 


\section{New material examined}

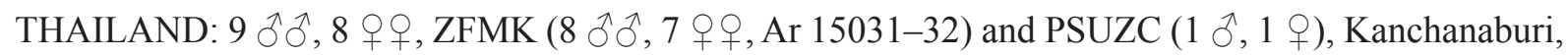
Erawan National Park $\left(14^{\circ} 22.2^{\prime} \mathrm{N}, 9^{\circ} 08.75^{\prime} \mathrm{E}\right), 85 \mathrm{~m}$ a.s.1., forest along stream, on rocks and tree roots, 15 Mar. 2015 (B.A. Huber, B. Petcharad); 2 우, in absolute ethanol, ZFMK (Mal 379), same data; 1 ðૈ, 2 우, RMNH, Erawan National Park, 15-16 Mar. 1986 (C.L. \& P.R. Deeleman).

\section{Assigned tentatively}

THAILAND: $3 \hat{\jmath} \widehat{\partial}, 3$ 우, ZFMK (Ar 15033), Prachuap Khiri Khan, Khao Sam Roi Yot National Park, near Tham Phraya Nakhon (12 $\left.12.0^{\prime} \mathrm{N}, 100^{\circ} 00.8^{\prime} \mathrm{E}\right), 40 \mathrm{~m}$ a.s.l., at rocks in forest, 14 Mar. 2015 (B.A. Huber, B. Petcharad); 2 q $ᄋ, 3$ juvs, in absolute ethanol, ZFMK (Mal 373), same data; 1 ㅇ, ZFMK (Ar 15034), Khao Sam Roi Yot National Park, Tham Kaeo (12¹2.2' N, 9959.5' E), 60 m a.s.1., under rock in cave entrance, 14 Mar. 2015 (B.A. Huber, B. Petcharad); 1 q, RMNH, Sam Roi Yot National Park, no further locality information, 8 Dec. 1990 (C.L. \& P.R. Deeleman); 1 juv., in absolute ethanol, ZFMK (Mal 376), Wat Huai Takaeng (1335.23' N, 9945.52' E) (= "Tham Phraya Prap" in Huber 2011), 30 m a.s.l., in cave, 15 Mar. 2015 (B.A. Huber, B. Petcharad).

\section{Description - amendments}

In males from Khao Sam Roi Yot, the uncus has a slightly more pointed tip and the subdistal spine on the embolus has a more transversal position relative to the embolus. Specimens from this locality are therefore assigned tentatively. Tibia 1 in 7 males from type locality (Erawan): 8.7-10.6 (mean 9.9); in 7 females: 7.5-8.6 (mean 8.1). Hairs on male ocular area not visibly different from those in females (Figs 79-80); tarsus 4 comb-hairs of the simplified Pholcus-type (cf. Huber \& Fleckenstein 2008), with three lateral tines (Fig. 82); procursus with distinctive field of ventral spines (Figs 83, 89); male distal cheliceral apophyses with two modified hairs each (Fig. 86); gonopore with four epiandrous spigots (Fig. 88); ALS with one widened, one pointed, and six smaller cylindrically shaped spigots of varying sizes (Fig. 81).

\section{Natural history}

At the type locality (Erawan) most specimens were found on the lower surfaces of exposed tree roots at the riverside. At the other localities, specimens were only found on overhanging smooth rocks at the cave entrances (Tham Kaeo; Wat Huai Takaeng) or in the forest (Phraya Nakhon). When disturbed, the spiders dropped to the ground.

\section{Distribution}

Known from four localities in central western Thailand (Fig. 57).

\section{Pholcus krabi species group}

This species group is newly proposed to include three species previously part of the $P h$. halabala group (Ph. chiangdao Huber, 2011; Ph. khene Huber, 2011; Ph. kinabalu Huber, 2011) as well as three newly described species (Ph. krabi Huber, sp. nov.; Ph. narathiwat Huber, sp. nov.; Ph. kipungit Huber, sp. nov.). They share three putative synapomorphies: (1) absence of AME (Figs 116-117); (2) absence of modified hairs on distal male cheliceral apophyses (Fig. 118); and (3) reduction of ALS spigots to two (one widened, one pointed; Fig. 122; confirmed in Ph. kinabalu and Ph. krabi sp. nov. only). In addition, live males of the three newly described species share highly distinctive reddish to orange palps (Figs 102, 106, 108), and females of at least Ph. chiangdao, Ph. kinabalu, and Ph. narathiwat sp. nov. share dimorphic color patterns on the prosoma. Species newly observed in the field (Ph. kipungit sp. nov.; Ph. narathiwat sp. nov.; Ph. krabi sp. nov.) built very similar domed webs among the vegetation $(0.5-2 \mathrm{~m}$ above the ground), usually with the apex of the dome attached to the underside of a leaf. They are also 
very similar in general appearance (the three species are indistinguishable in the field; Figs 102-109). Very low abundances and/or patchy distributions were observed in all three species. However, most specimens known of Ph. kinabalu were collected by canopy fogging (Huber 2011), suggesting that abundances of at least this species may be different in higher forest strata. Egg-sacs are carried in front of the body (Figs 105, 109) as in typical pholcids. This species group is known from mainland Southeast Asia and Borneo (Fig. 110). The RMNH has an additional species from East Kalimantan (Fig. 110) that is not described here because only a single poorly preserved male specimen is available.

\section{Pholcus krabi Huber, sp. nov. urn:1sid:zoobank.org:act:A078EA4B-89F1-4E10-8592-DF39683AFA43}

Figs 102-105, 111-123, 134-136

\section{Diagnosis}

Distinguished from similar species (other species in the Ph. krabi group) by morphology of male palps (Figs 111-112; unique shapes of small uncus and small appendix; distinctive procursus with prolateral process ending in heavily sclerotized tip) and by distinctive pair of small dark internal structures in internal female genitalia (arrow in Fig. 114).

\section{Etymology}

The species name is derived from the type locality; noun in apposition.

\section{Type material}

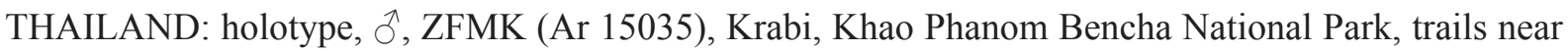
headquarters $\left(8^{\circ} 14.6^{\prime} \mathrm{N}, 98^{\circ} 55.0^{\prime} \mathrm{E}\right), 110 \mathrm{~m}$ a.s.l., domed webs among forest vegetation, 8 Mar. 2015 (B.A. Huber, B. Petcharad).

\section{Other material examined}

THAILAND: $3 \widehat{\partial}, 4$ 우, ZFMK (Ar 15036-37), same data as holotype; 2 q $q, 4$ juvs, in absolute ethanol, ZFMK (Mal 338), same data; 2 $\widehat{\jmath}, 5$ 우, ZFMK (Ar 15038-39), Surat Thani, Khao Sok National Park, forest along nature trail ( $\left.8^{\circ} 54.8^{\prime} \mathrm{N}, 98^{\circ} 29.3^{\prime}-98^{\circ} 30.5^{\prime} \mathrm{E}\right)$, domed webs among vegetation, 110-160 m a.s.1., 11-12 Mar. 2015 (B.A. Huber, B. Petcharad); 3 우, in absolute ethanol, ZFMK

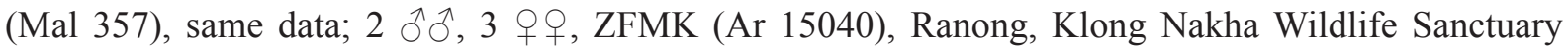
$\left(9^{\circ} 27.6^{\prime} \mathrm{N}, 98^{\circ} 30.7^{\prime} \mathrm{E}\right), 40 \mathrm{~m}$ a.s.1., forest, domed webs among vegetation, 12 Mar. 2015 (B.A. Huber, B. Petcharad); 3 우, in absolute ethanol, ZFMK (Mal 363), same data.

\section{Description}

\section{Male (holotype)}

MeAsurements. Total body length 4.1, carapace width 0.95. Leg 1: $34.8(8.3+0.4+8.3+15.5+2.3)$, tibia 2: 5.2, tibia 3: 2.9, tibia 4: 4.5; tibia 1 L/d: 86. Distance PME-PME $375 \mu \mathrm{m}$, diameter PME $105 \mu \mathrm{m}$, distance PME-ALE $\sim 35 \mu \mathrm{m}$; AME absent.

CoLOR. Carapace pale ochre to whitish with small dark median mark, ocular area and clypeus with light brown pattern; sternum whitish; palps reddish; legs pale ochre to whitish with brown patellae and tibia-metatarsus joints; abdomen pale gray with very indistinct darker marks dorsally and laterally, monochromous ventrally.

BoDy. Habitus as in Figs 102-103; ocular area slightly raised and each triad on short stalk directed laterad (Fig. 116); carapace without median furrow; clypeus unmodified; sternum wider than long $(0.60 / 0.48)$, unmodified. ALS with only two spigots (one widened, one pointed; Fig. 122). 
Chelicerae. As in Fig. 113, with large proximal processes and pair of rounded distal apophyses without modified hairs (Fig. 118).

PALPS. As in Figs 111-112; coxa unmodified; trochanter with long retrolatero-ventral apophysis directed first laterad then bending sharply ventrad (Fig. 119); femur with small retrolatero-dorsal process; tibia large; procursus with distinctive prolateral process ending in heavily sclerotized tip (Fig. 120), with sclerotized and membranous pointed processes ventrally; bulb with indistinct prolateral process, strong proximal sclerite, small uncus and small appendix (Fig. 121), weakly sclerotized embolus.

LEGS. Without spines and curved hairs; few vertical hairs; retrolateral trichobothrium on tibia 1 at 3\%; prolateral trichobothrium absent on tibia 1, present on other tibiae; tarsus 1 pseudosegments not seen in dissecting microscope. Tarsus 4 comb-hairs of the simplified Pholcus-type (cf. Huber \& Fleckenstein 2008), with five lateral tines (Fig. 123).
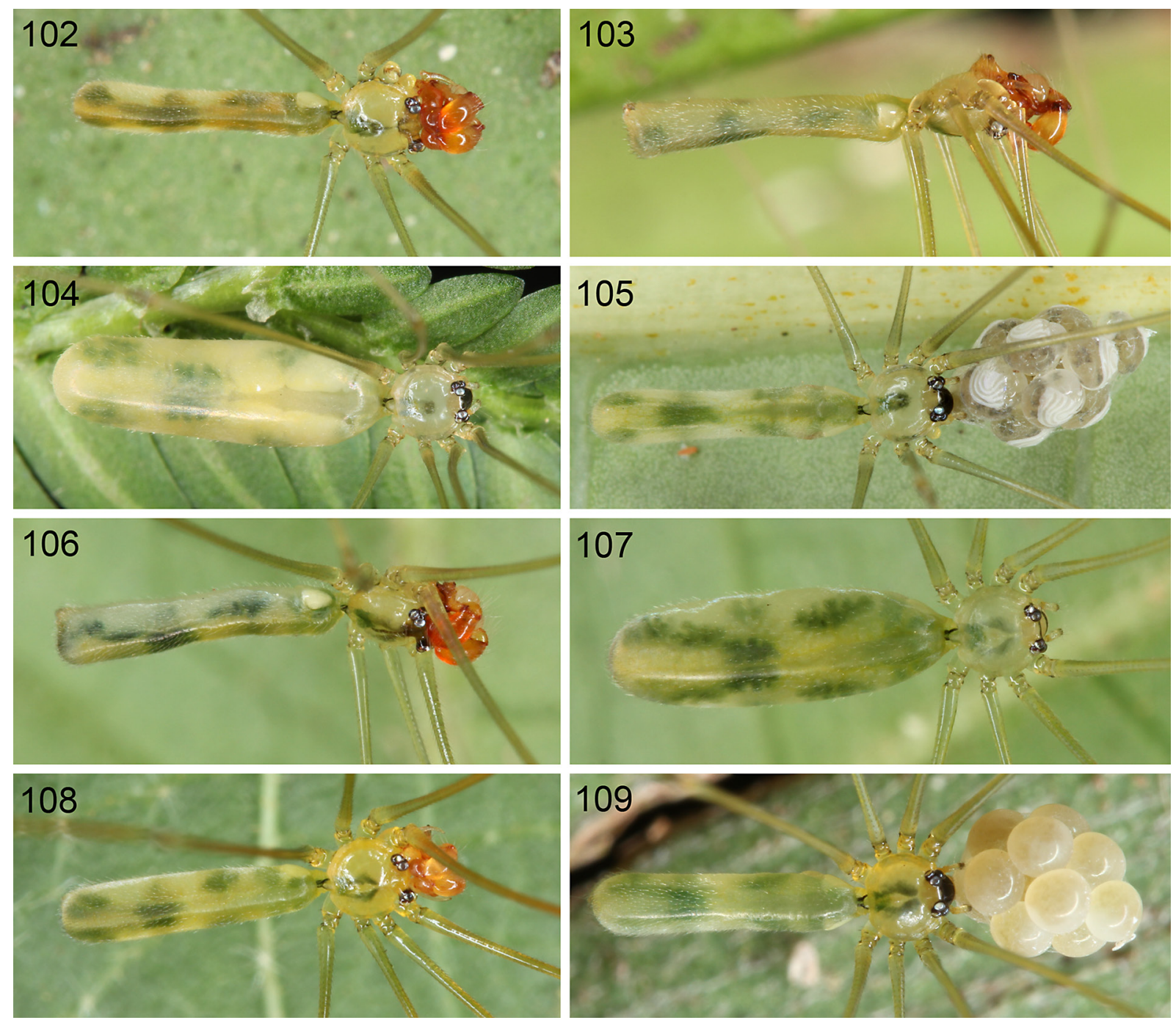

Figs 102-109. Live specimens, Pholcus krabi Huber, sp. nov. (102-105), Ph. narathiwat Huber, sp. nov. (106-107), and Ph. kipungit Huber, sp. nov. (108-109). 102-104. $\delta^{\lambda}$ and + from Khao Sok, Thailand. 105. $q$ with egg-sac from Phanom Bencha, Thailand. 106-107. $\delta$ and $q$ from Hala Bala, Thailand. 108-109. $\delta$ and $q$ from Poring, Sabah. 
Male (variation)

Tibia 1 in 6 other males: 7.7-8.3 (mean 8.1).

\section{Female}

In general similar to male (Figs 104-105) but eye triads on low humps and closer together (Fig. 117; PME-PME distance: $220 \mu \mathrm{m}$ ); clypeus and ocular area frontally black; sternum anterior part slightly darker. Tibia 1 in 12 females: 6.3-7.3 (mean 6.8). Epigynum weakly sclerotized slightly bulging plate with semi-transparent posterior 'knob', internal anterior arch and distinctive small sclerites visible through cuticle (Figs 114, 134-135); internal genitalia as in Figs 115 and 136, with straight anterior sclerite and oval pore plates.

\section{Natural history}

At Phanom Bencha, all eight specimens were collected from two bushes close to each other. Two days of intensive search in various parts of the forest did not result in any further specimens. At Khao Sok, all specimens were found in degraded forest close to the park road; none was found in well preserved forest.

\section{Distribution}

Known from three localities in southern Thailand (Fig. 110).

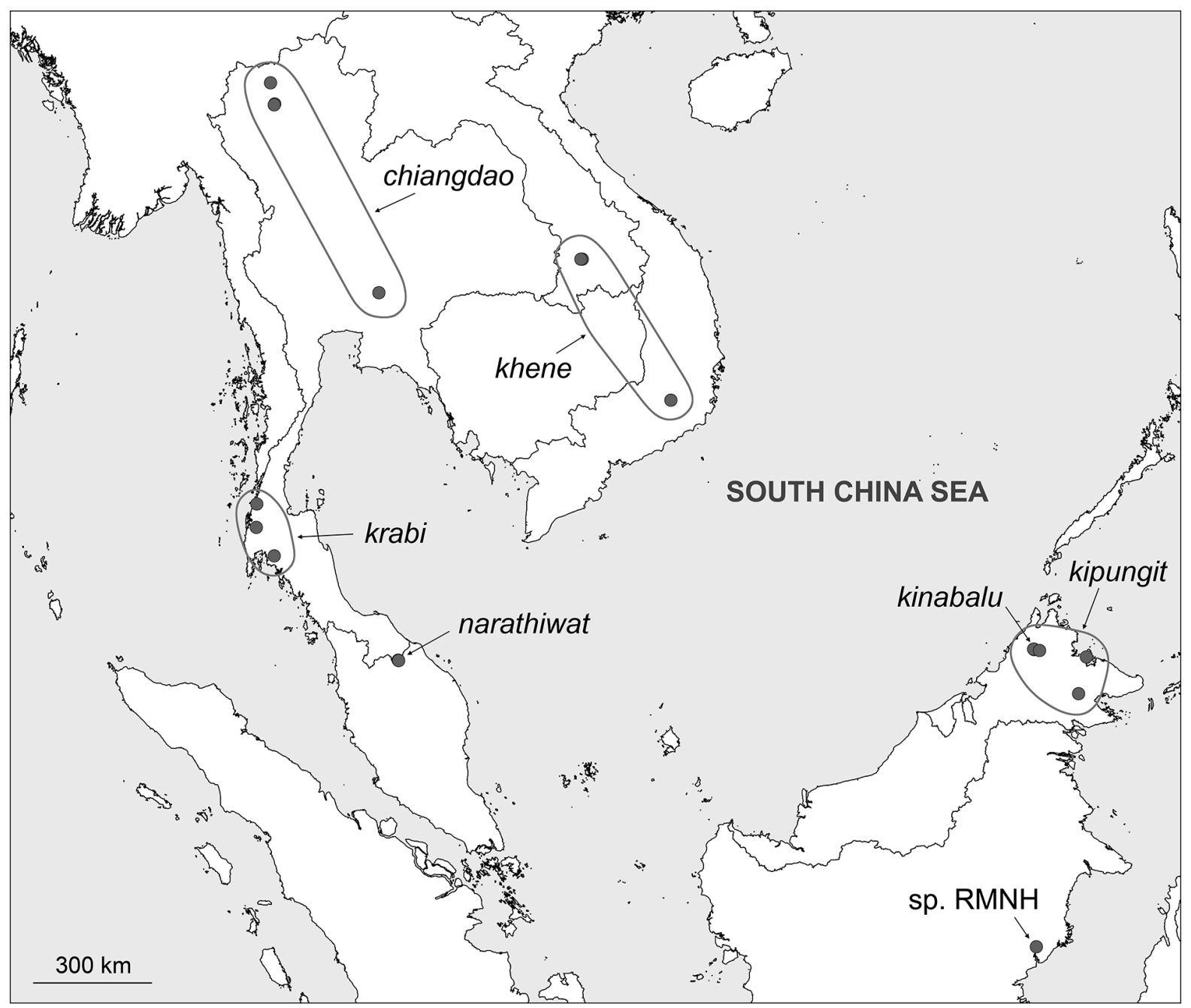

Fig. 110. Known distribution of the Pholcus krabi species group. 


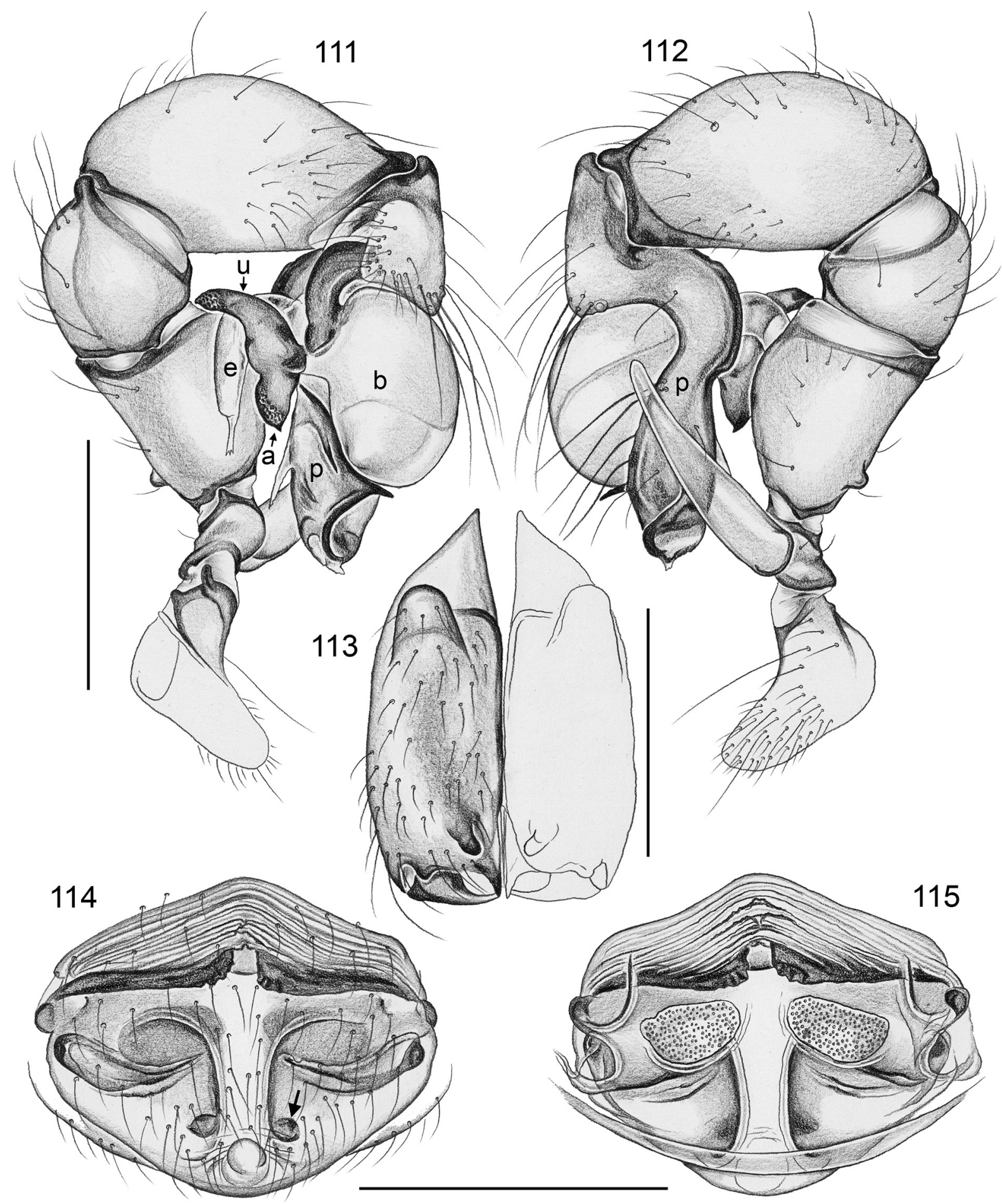

Figs 111-115. Pholcus krabi Huber, sp. nov., ZFMK Ar 15036-37. 111-112. Left male palp, prolateral and retrolateral views. 113. Male chelicerae, frontal view. 114-115. Cleared female genitalia, ventral and dorsal views (arrow points at distinctive small dark internal structure). Abbreviations: $\mathrm{a}=$ appendix; $\mathrm{b}=$ genital bulb; $\mathrm{e}=$ embolus; $\mathrm{p}=$ procursus; $\mathrm{u}=$ uncus. Scale lines: $0.3 \mathrm{~mm}(113), 0.5 \mathrm{~mm}(111-112$, 114-115). 

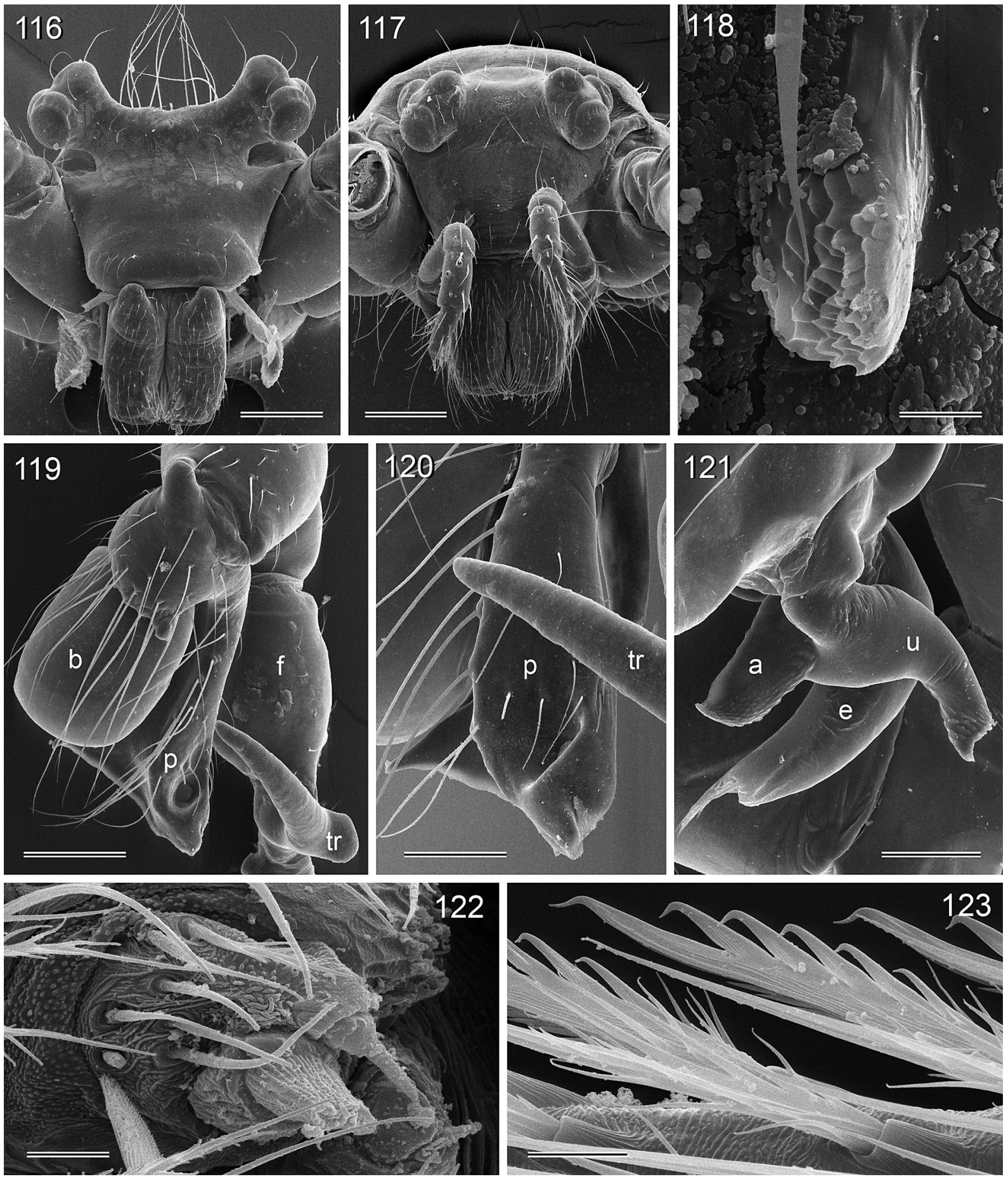

Figs 116-123. Pholcus krabi Huber, sp. nov., ZFMK Ar 15038-39. 116-117. Male and female prosomata, frontal views. 118. Male distal cheliceral apophysis. 119. Left male palp, dorsal view. 120. Left procursus (and trochanter apophysis), retrolateral view. 121. Right bulbal processes, prolateral (slightly ventral) view. 122. Male ALS. 123. Comb-hairs on male tarsus 4. Abbreviations: $a=$ appendix; $b=$ genital bulb; $\mathrm{e}=$ embolus; $\mathrm{f}=$ femur; $\mathrm{p}=$ procursus; $\mathrm{tr}=$ trochanter; $\mathrm{u}=$ uncus. Scale lines: $8 \mu \mathrm{m}(123) ; 10 \mu \mathrm{m}(118$, 122); $80 \mu \mathrm{m}$ (121); $100 \mu \mathrm{m}$ (120); $200 \mu \mathrm{m}$ (116-117, 119). 


\section{Pholcus narathiwat Huber, sp. nov. urn:Isid:zoobank.org:act:0127E1C4-BABC-4C33-A92E-65744D43D8E2}

Figs 106-107, 124-128, 137-139

\section{Diagnosis}

Distinguished from similar species (other species in the Ph. krabi group) by morphology of male palps (Figs 124-125; unique shape of bifid appendix; shape of uncus; procursus with strong distal ventral sclerite, similar only in $P h$. chiangdao) and by distinctive rounded sclerites in internal female genitalia (Fig. 127).

\section{Etymology}

The species name is derived from the type locality; noun in apposition.

\section{Type material}

THAILAND: holotype, Ô, ZFMK (Ar 15041), Narathiwat, Hala Bala Wildlife Sanctuary, 'site 3' $\left(5^{\circ} 48.4^{\prime} \mathrm{N}, 101^{\circ} 49.4^{\prime} \mathrm{E}\right), 180 \mathrm{~m}$ a.s.1., forest near road, domed webs among vegetation, 2 Mar. 2015 (B.A. Huber, B. Petcharad).

\section{Other material examined}

THAILAND: $1 q$, together with holotype; 1 , in absolute ethanol, ZFMK (Mal 312), same data but at $220 \mathrm{~m}$ a.s.1.; 1 q, in absolute ethanol, ZFMK (Mal 316), same locality but 'site 1', forest at river near headquarters $\left(5^{\circ} 47.8^{\prime} \mathrm{N}, 101^{\circ} 49.9^{\prime} \mathrm{E}\right), 90$ m a.s.1., 2 Mar. 2015 (B.A. Huber, B. Petcharad), night collecting.

\section{Description}

\section{Male (holotype)}

MEAsurements. Total body length 3.9, carapace width 1.0. Leg 1: $30.6(7.2+0.4+7.3+13.5+2.2)$, tibia 2: 4.4, tibia 3: 2.4, tibia 4: 4.1; tibia $1 \mathrm{~L} / \mathrm{d}$ : 76. Distance PME-PME $350 \mu \mathrm{m}$, diameter PME $95 \mu \mathrm{m}$, distance PME-ALE $\sim 35 \mu \mathrm{m}$; AME absent.

CoLOR. Carapace pale ochre-yellow with light brown median line and V-mark, ocular area and clypeus light brown; sternum whitish; palps orange; legs pale ochre-yellow with darker brown patellae and tibiametatarsus joints; abdomen pale gray with some indistinct marks dorsally.

Body. Habitus as in Fig. 106; ocular area slightly raised and each triad on short stalk directed laterad; carapace without median furrow; clypeus unmodified; sternum wider than long $(0.60 / 0.52)$, unmodified.

Chelicerae. As in Fig. 126, with large proximal lateral processes and pair of rounded distal apophyses without modified hairs.

PaLPS. As in Figs 124-125; coxa unmodified; trochanter with retrolatero-ventral apophysis directed first laterad then bending sharply ventrad; femur with small retrolatero-dorsal process proximally; tibia large; procursus distally complex, with distinctive strong ventral apophysis; bulb with strong proximal sclerite, with uncus, with distinctive bifid appendix (prolateral part with large scales), short weakly sclerotized embolus.

LEGS. Without spines and curved hairs; few vertical hairs; retrolateral trichobothrium on tibia 1 at $4 \%$; prolateral trichobothrium absent on tibia 1, present on other tibiae; tarsus 1 with $>20$ pseudosegments, only distally fairly distinct. 


\section{Female}

In general similar to male (Fig. 107) but eye triads on low humps and closer together (PME-PME distance: $235 \mu \mathrm{m}$ ), ocular area and clypeus either with one large black mark (1 +) or with two transversal black bands $(2$ 우). Tibia 1: 5.9, 6.3, 6.6. Epigynum weakly sclerotized slightly bulging plate with posterior 'knob', internal anterior arch and distinctive rounded sclerites poorly visible through cuticle (Figs 127, 137-138); internal genitalia as in Figs 128 and 139.

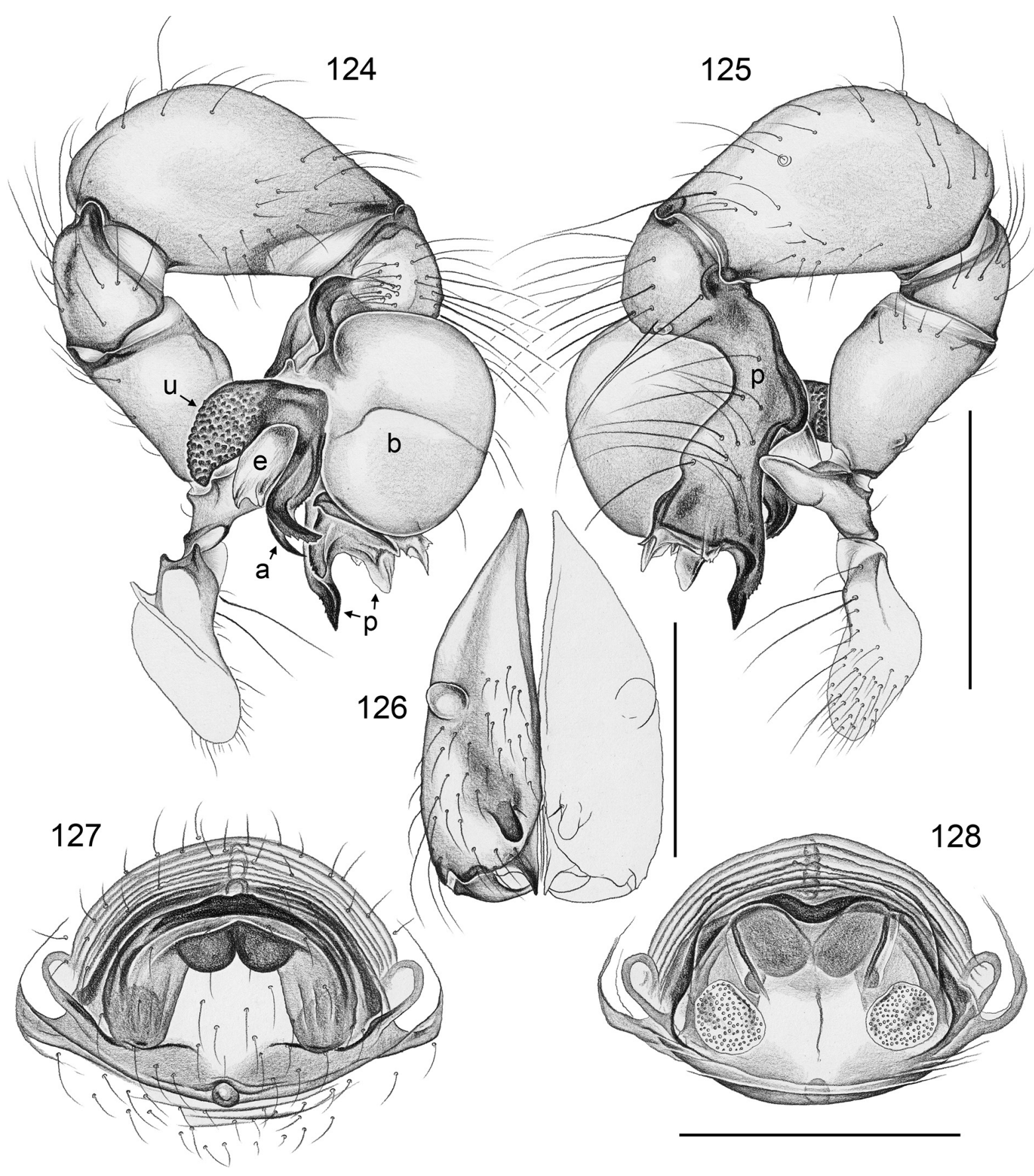

Figs 124-128. Pholcus narathiwat Huber, sp. nov., ZFMK Ar 15041. 124-125. Left male palp, prolateral and retrolateral views. 126. Male chelicerae, frontal view. 127-128. Cleared female genitalia, ventral and dorsal views. Abbreviations: $\mathrm{a}=$ appendix; $\mathrm{b}=$ genital bulb; $\mathrm{e}=$ embolus; $\mathrm{p}=$ procursus; $\mathrm{u}=$ uncus. Scale lines: $0.3 \mathrm{~mm}$ (126), $0.5 \mathrm{~mm}$ (124-125, 127-128). 


\title{
Natural history
}

Three of the four specimens were collected from a single bush. Three days of intensive collecting at the type locality resulted in only one further specimen. The ATOL Expedition in 2003 did not collect this species. The domed webs were easily visible among the vegetation, about $1-1.5 \mathrm{~m}$ above the ground.

\section{Distribution}

Known from type locality in southern Thailand only (Fig. 110).

\author{
Pholcus kipungit Huber, sp. nov. \\ urn:1sid:zoobank.org:act:374082FB-1878-493D-A8B6-CC148D8BB223
}

Figs 108-109, 129-133, 140-142

\section{Diagnosis}

Distinguished from similar species (other species in the Ph. krabi group) by morphology of male palps (Figs 129-130; long trochanter apophysis; distinctive shapes of simple round uncus and small appendix; procursus strongly bent dorsad, with distinctive prolatero-ventral pointed process and fringed membranous distal elements) and by unique median sclerite in internal female genitalia visible through cuticle (Figs 132, 140).

\section{Etymology}

The species name is derived from the type locality; noun in apposition.

\section{Type material}

MALAYSIA-BORNEO: holotype, $\widehat{\partial}$, ZFMK (Ar 15042), Sabah, Mt Kinabalu, Poring Hot Springs, forest near beginning of Kipungit Trail $\left(6.048^{\circ} \mathrm{N}, 116.706^{\circ} \mathrm{E}\right), 450 \mathrm{~m}$ a.s.l., domed webs in vegetation, 7 Aug. 2014 (B.A. Huber, S.B. Huber).

\section{Other material examined}

MALAYSIA-BORNEO: 1 , together with holotype; 2 + $q$, in absolute ethanol, ZFMK (Bor 205), same data; $1 \delta^{\lambda}$, RMNH, Sabah, Poring Hot Springs $\left(6^{\circ} 03.467^{\prime}\right.$ N, 116 $42.205^{\prime}$ E), 9 Aug. 2009 (A. Floren); 1 ठ, 2 juvs, RMNH, Poring Hot Springs, $500 \mathrm{~m}$ a.s.1., primary forest, 2 May 1991 (C.L. \& P.R. Deeleman); 1 , , ZFMK (Ar 15043), Sabah, Sepilok, Rainforest Discovery Centre, forest along Pitta Trail $\left(5.875-5.878^{\circ} \mathrm{N}, 117.937-117.942^{\circ} \mathrm{E}\right), 30 \mathrm{~m}$ a.s.l., domed web among vegetation, 9 Aug.

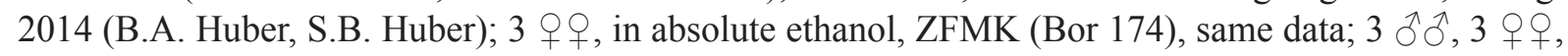
RMNH (2 vials), Sabah, Danum Valley [5.022 ${ }^{\circ}$ N, $117.747^{\circ}$ E], primary forest, 6-16 May 1991 (C.L. \& P.R. Deeleman).

\section{Description}

\section{Male (holotype)}

Measurements. Total body length 3.7, carapace width 0.9. Leg 1: $32.1(7.5+0.4+7.4+14.3+2.5)$, tibia 2: 4.5, tibia 3: 2.5, tibia 4: 4.1; tibia $1 \mathrm{~L} / \mathrm{d}: 84$. Distance PME-PME $270 \mu \mathrm{m}$, diameter PME $95 \mu \mathrm{m}$, distance PME-ALE $\sim 35 \mu \mathrm{m}$; AME absent.

COLOR. Carapace pale whitish to gray with pair of light brown marks, ocular area and clypeus not darkened; sternum whitish; palps orange; legs pale ochre-yellow with dark patellae and tibia-metatarsus joints; abdomen pale gray with some indistinct darker marks dorsally.

BoDy. Habitus as in Fig. 108; ocular area slightly raised and each triad on low hump; carapace without median furrow; clypeus unmodified; sternum wider than long $(0.60 / 0.50)$, unmodified. 
Chelicerae. As in Fig. 131, with small proximal processes and pair of rounded distal apophyses without modified hairs.

PaLPs. As in Figs 129-130; coxa unmodified; trochanter with very long retrolatero-ventral apophysis with retrolateral process proximally; femur with small retrolatero-ventral process proximally; tibia

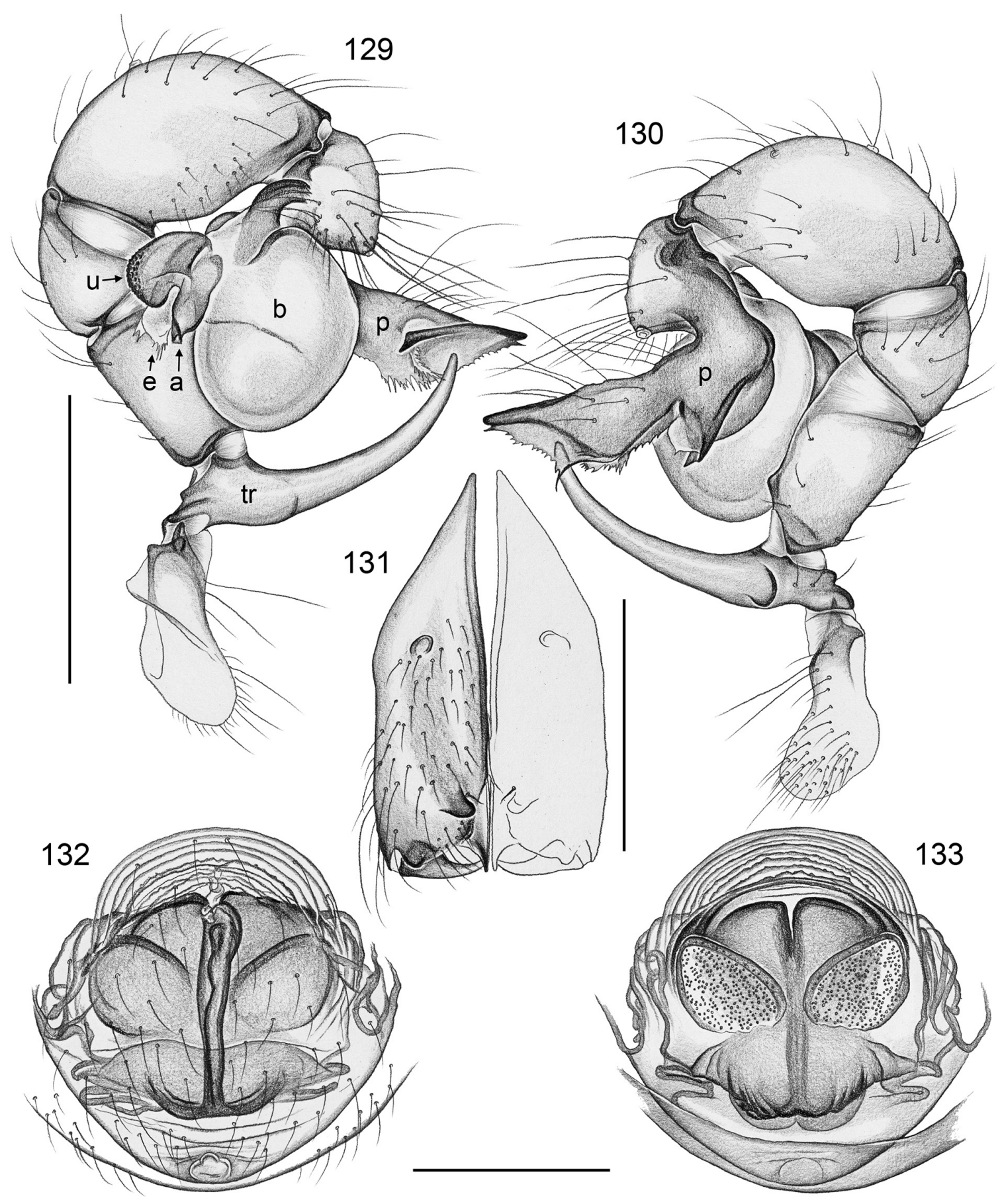

Figs 129-133. Pholcus kipungit Huber, sp. nov., ZFMK Ar 15042. 129-130. Left male palp, prolateral and retrolateral views. 131. Male chelicerae, frontal view. 132-133. Cleared female genitalia, ventral and dorsal views. Abbreviations: $\mathrm{a}=$ appendix; $\mathrm{b}=$ genital bulb; $\mathrm{e}=$ embolus; $\mathrm{p}=$ procursus; $\mathrm{tr}=$ trochanter; $\mathrm{u}=$ uncus. Scale lines: $0.3 \mathrm{~mm}(131-133), 0.5 \mathrm{~mm}(129-130)$. 
large; procursus strongly bent dorsad, with distinctive prolatero-ventral pointed process and fringed membranous distal elements; bulb with strong proximal sclerite, with small uncus and small appendix, short weakly sclerotized embolus.

LEGS. Without spines and curved hairs; few vertical hairs; retrolateral trichobothrium on tibia 1 at $3 \%$; prolateral trichobothrium absent on tibia 1, present on other tibiae; tarsus 1 with $>30$ pseudosegments, only distally fairly distinct.

\section{Female}

In general similar to male (Fig. 109) but eye triads closer together (PME-PME distance: $195 \mu \mathrm{m}$ ), entire clypeus and ocular area frontally black; legs pale ochre, less yellowish. Tibia 1: 6.7, 6.9 (missing in other females). Epigynum weakly sclerotized almost flat plate with posterior 'knob', internal distinctive median sclerite visible through cuticle (Figs 132, 140-141); internal genitalia as in Figs 133 and 142.

\section{Natural history}

Of the four webs seen at Poring, three had their apex connected to the underside of a leaf; the fourth (of the only male) was freely suspended among the twigs at about $1.5 \mathrm{~m}$ above the ground.
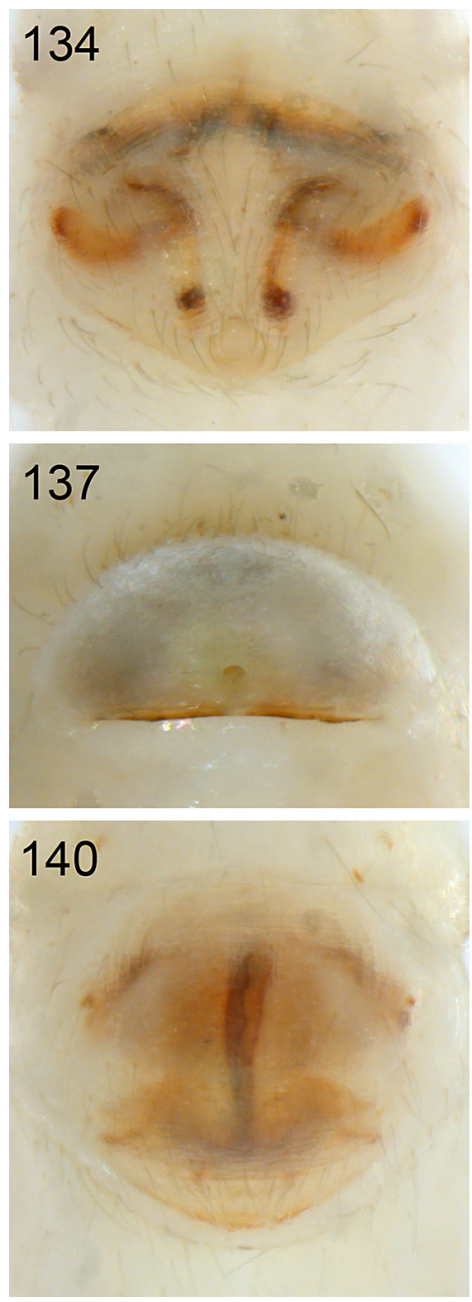
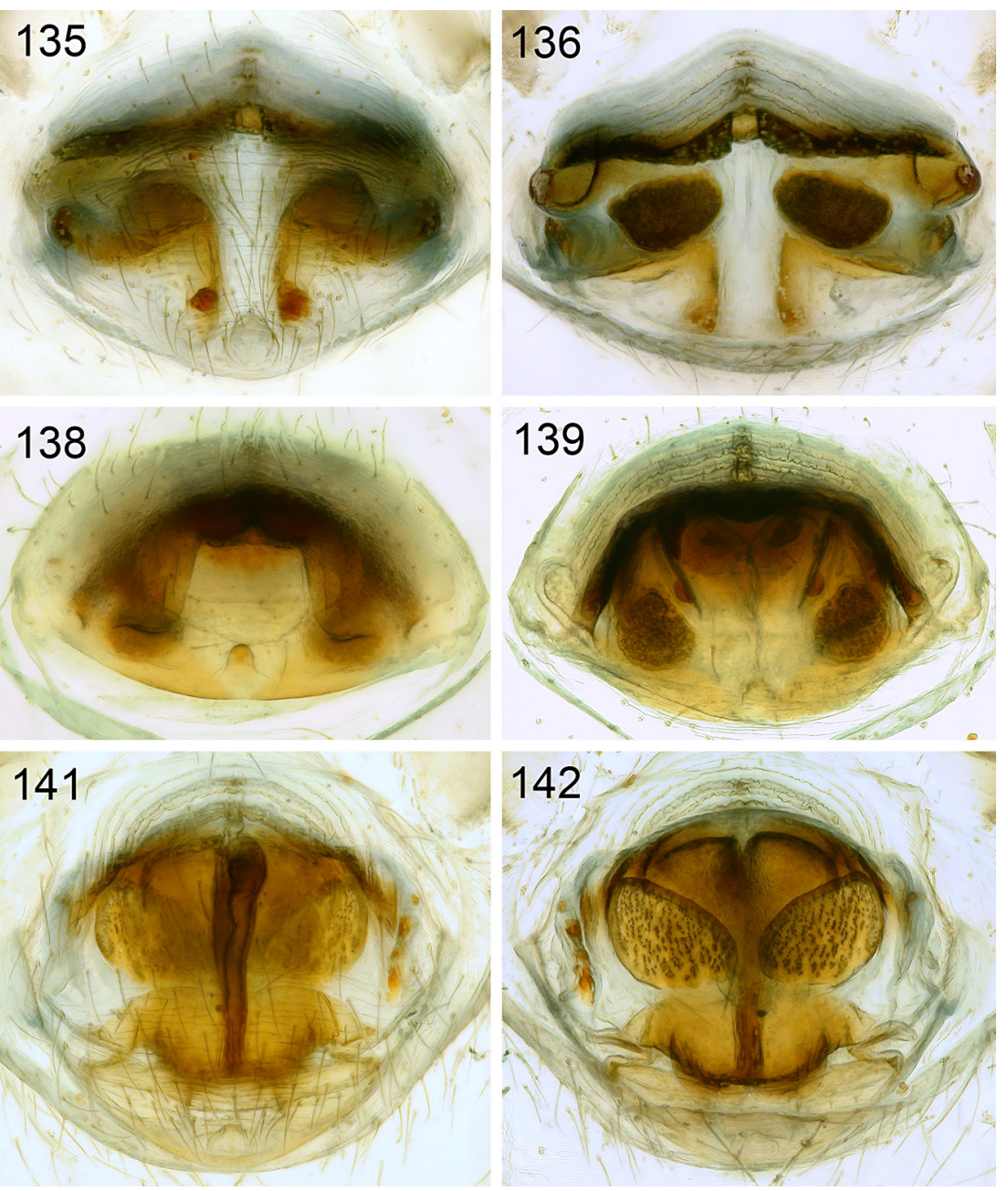

Figs 134-142. Female genitalia, untreated in ventral view, cleared in ventral and dorsal views. 134136. Pholcus krabi Huber, sp. nov. 137-139. Ph. narathiwat Huber, sp. nov. 140-142. Ph. kipungit Huber, sp. nov. 


\section{Distribution}

Known from two localities in Sabah (Fig. 110).

Pholcus kinabalu Huber, 2011

Pholcus kinabalu Huber, 2011: 138-141, figs 511-514, 527-528, 556-569 (ぷ).

\section{Diagnosis}

Distinguished from other species in krabi group by male palpal morphology (triangular appendix provided with scales; rather short pointed trochanter apophysis; fig. 556 in Huber 2011) and female internal genitalia (large round pore plates far from each other; fig. 559 in Huber 2011).

\section{New material examined}

MALAYSIA-BORNEO: 1 ô, RMNH, Sabah, Mt Kinabalu National Park, Poring Hot Springs $\left(6^{\circ} 02^{\prime} \mathrm{N}\right.$, $116^{\circ} 50^{\prime} \mathrm{E}$, coordinates dubious), canopy fogging, 20 Jan. 1992 (A. Floren); 1 ô, 2 q 9 , 4 juvs, RMNH, same locality, canopy fogging, 19 Feb.-26 Mar. 1996 (A. Floren); 1 đૈ, 3 q $q$, RMNH, Poring Hot Springs ( $6^{\circ} 05^{\prime} \mathrm{N}, 116^{\circ} 33^{\prime} \mathrm{E}$, coordinates dubious), 16 Sep. 2006 (A. Floren).

\section{Pholcus buatong species group}

This species group is newly proposed to include one species previously part of the $P h$. halabala group (Ph. satun Huber, 2011), one species previously tentatively assigned to the Pholcus ethagala group (Ph. schwendingeri Huber, 2011), and a newly described species (Ph. buatong Huber, sp. nov.). They share three putative synapomorphies, (1) the complete reduction of distal anterior apophyses on the male chelicerae (Fig. 156); (2) the very distinctive dorsal bulging of the male palpal patella (Fig. 155; angle between femur and patella $\sim 120-125^{\circ}$ rather than $\sim 180^{\circ}$ as in typical pholcids); and (3) the large, heavily sclerotized 'knob' on the epigynum (Figs 184, 187, 190). The group is strongly supported by preliminary molecular data (A. Valdez-Mondragón, B.A. Huber \& D. Dimitrov unpublished data). Pholcus schwendingeri and Ph. buatong sp. nov. also share a distinctive whitish membranous process retrolatero-distally on the procursus (arrows in Figs 155, 180). Otherwise this group appears rather inhomogeneous: Pholcus schwendingeri males have extremely long eye stalks (Fig. 173) while males of the other two species have short eye stalks (Fig. 155); Pholcus buatong sp. nov. is rock-dwelling while the other two species are leaf litter dwelling; Pholcus satun has small AME, while the other two species lack AME; Pholcus satun males have only one bulbal process (sclerotized embolus), while males of the other two species have a membranous embolus plus an appendix. In all three species, egg-sacs are carried in front of the body (Figs 145, 152) as in typical pholcids. This species group is known from southern Thailand and northern mainland Malaysia (Fig. 153).

\section{Pholcus buatong Huber, sp. nov. urn:1sid:zoobank.org:act:D2E21FAE-2ECD-414D-81E4-4C3CC7FC352F}

Figs 143-146, 154-168, 184-186

\section{Diagnosis}

Easily distinguished from known congeners by morphology of male palps (Figs 154-155; unique shape of procursus with transversal sclerotized ridges on retrolateral side and complex processes on prolateral side; slender appendix) and by internal female genitalia (large lateral sclerites; shape and position of pore plates; Figs 158, 186). From most congeners (except putatively closest relatives $P h$. satun and $P h$. schwendingeri) also by dorsally uniquely widened male palpal patella (Fig. 155) and by large sclerotized 'knob' on female external genitalia (Fig. 184). 
HUBER B.A. et al., Pholcus halabala group in Southeast Asia

\section{Etymology}

The species name is derived from one of the localities where this species was found; noun in apposition.

\section{Type material}

THAILAND: holotype, $\widehat{\partial}$, ZFMK (Ar 15044), Krabi, near Khao Phanom Bencha National Park, Tham Khao Phueng ( $8^{\circ} 14.16^{\prime}$ N, $98^{\circ} 54.26^{\prime}$ E), 45 m a.s.l., on walls in cave, 8 Mar. 2015 (B.A. Huber, B. Petcharad).
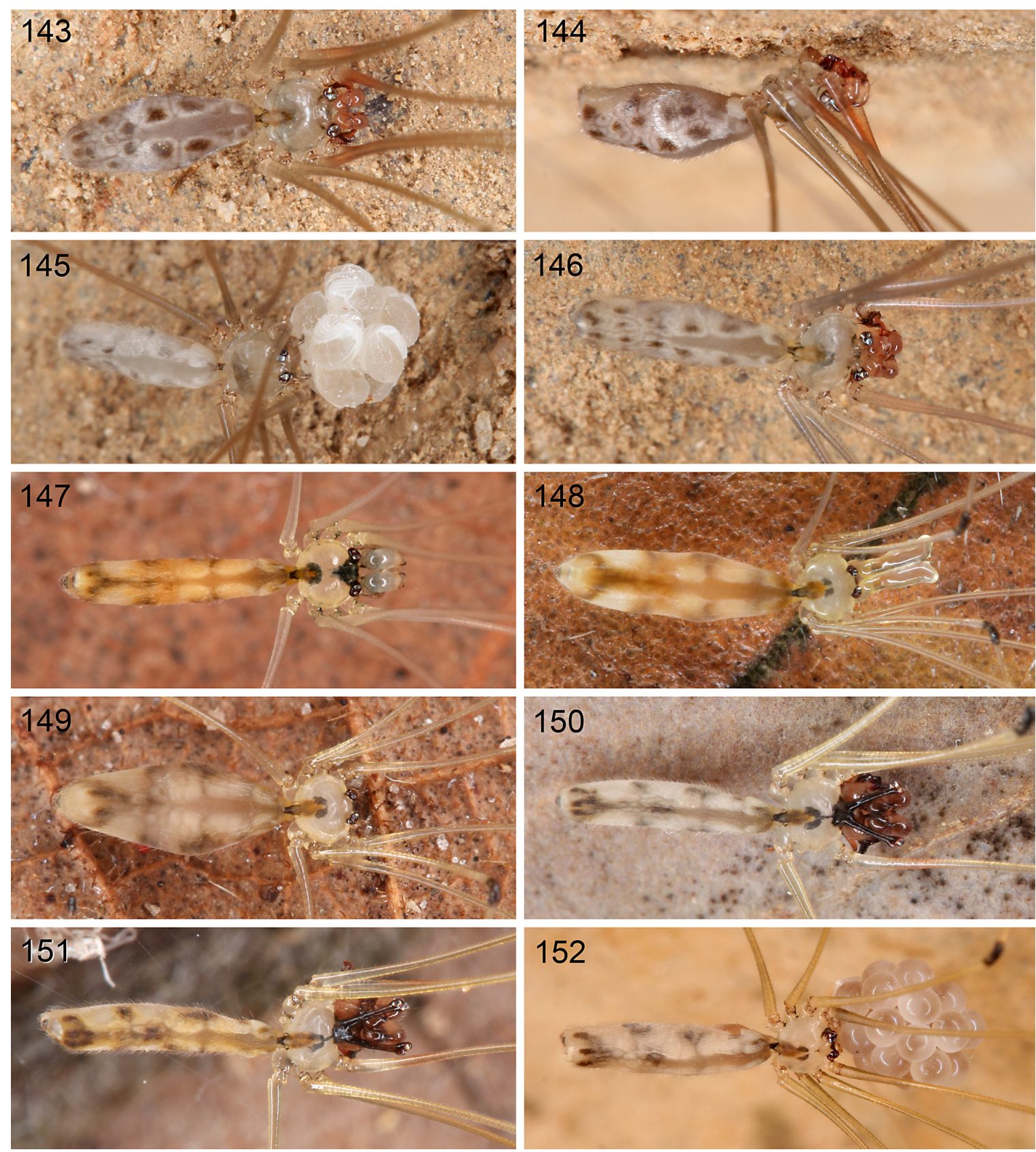

Figs 143-152. Live specimens, Pholcus buatong Huber, sp. nov. (143-146), Ph. satun Huber, 2011

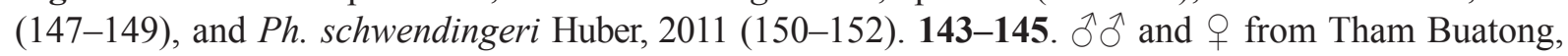
Thailand. 146. $\delta$ from Tham Khao Phueng, Thailand. 147-149. Adult $\hat{\partial}$, penultimate instar $\hat{\partial}$, and $q$ from Gunung Jerai, Malaysia. 150-151. $\widehat{\partial} \widehat{\partial}$ from Khao Sok, Thailand. 152. + with egg-sac, from Phanom Bencha, Thailand. 


\section{Other material examined}

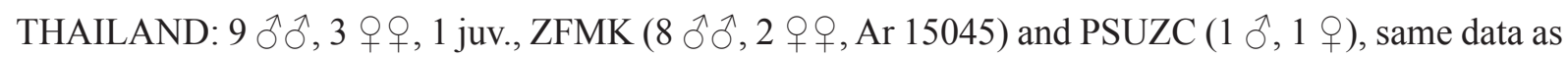
holotype; $2 \widehat{\jmath} \widehat{\partial}, 3$ 우, in absolute ethanol, ZFMK (Mal 335), same data; $3 \widehat{\partial} \widehat{\partial}, 1$ ㅇ, ZFMK (Ar 15046), $\sim 10 \mathrm{~km}$ N Krabi town, Tham Buatong $\left(8^{\circ} 10.83^{\prime} \mathrm{N}, 98^{\circ} 53.06^{\prime}\right.$ E), $50 \mathrm{~m}$ a.s.l., on cave walls, 7 Mar. 2015 (B.A. Huber, B. Petcharad); 3 q 9 , in absolute ethanol, ZFMK (Mal 332), same data.

\section{Description}

\section{Male (holotype)}

Measurements. Total body length 4.0, carapace width 1.0. Leg 1: $44.3(10.4+0.4+10.5+21.2+1.8)$, tibia 2: 7.1, tibia 3: 4.2, tibia 4: 5.9; tibia $1 \mathrm{~L} / \mathrm{d}: 120$. Distance PME-PME $370 \mu \mathrm{m}$, diameter PME $90 \mu \mathrm{m}$, distance PME-ALE 35 $\mu \mathrm{m}$; AME absent.

CoLor. Carapace pale ochre-grey with light brown posterior mark, ocular area with small median and pair of lateral brown marks; clypeus not darkened; sternum pale gray with small very indistinct darker marks; legs ochre-yellow with darker brown patellae and tibia-metatarsus joints; abdomen ochre-gray with some black and indistinct whitish marks dorsally and laterally, monochromous ventrally.

Body. Habitus as in Figs 143-144; ocular area slightly raised and each triad on short stalk directed obliquely dorsad (Fig. 159); carapace without median furrow; clypeus unmodified; sternum wider than long (0.60/0.50), unmodified. Gonopore with four epiandrous spigots (Fig. 167). ALS with one widened, one pointed, and six smaller cylindrically shaped spigots of varying sizes (Fig. 166).

Chelicerae. As in Fig. 156, barely modified, very indistinct frontal humps.

Palps. As in Figs 154-155; coxa unmodified; trochanter with long ventral apophysis and small hump at its basis; femur with small retrolatero-dorsal process proximally (Fig. 162) and rounded protrusion ventrally; patella dorsally characteristically widened, resulting in an angle between femur and patella of $\sim 120^{\circ}$ (lateral view); procursus very distinctive and complex, with transversal sclerotized ridges on retrolateral side and complex processes on prolateral side (Figs 162-164); bulb elongate, with strong

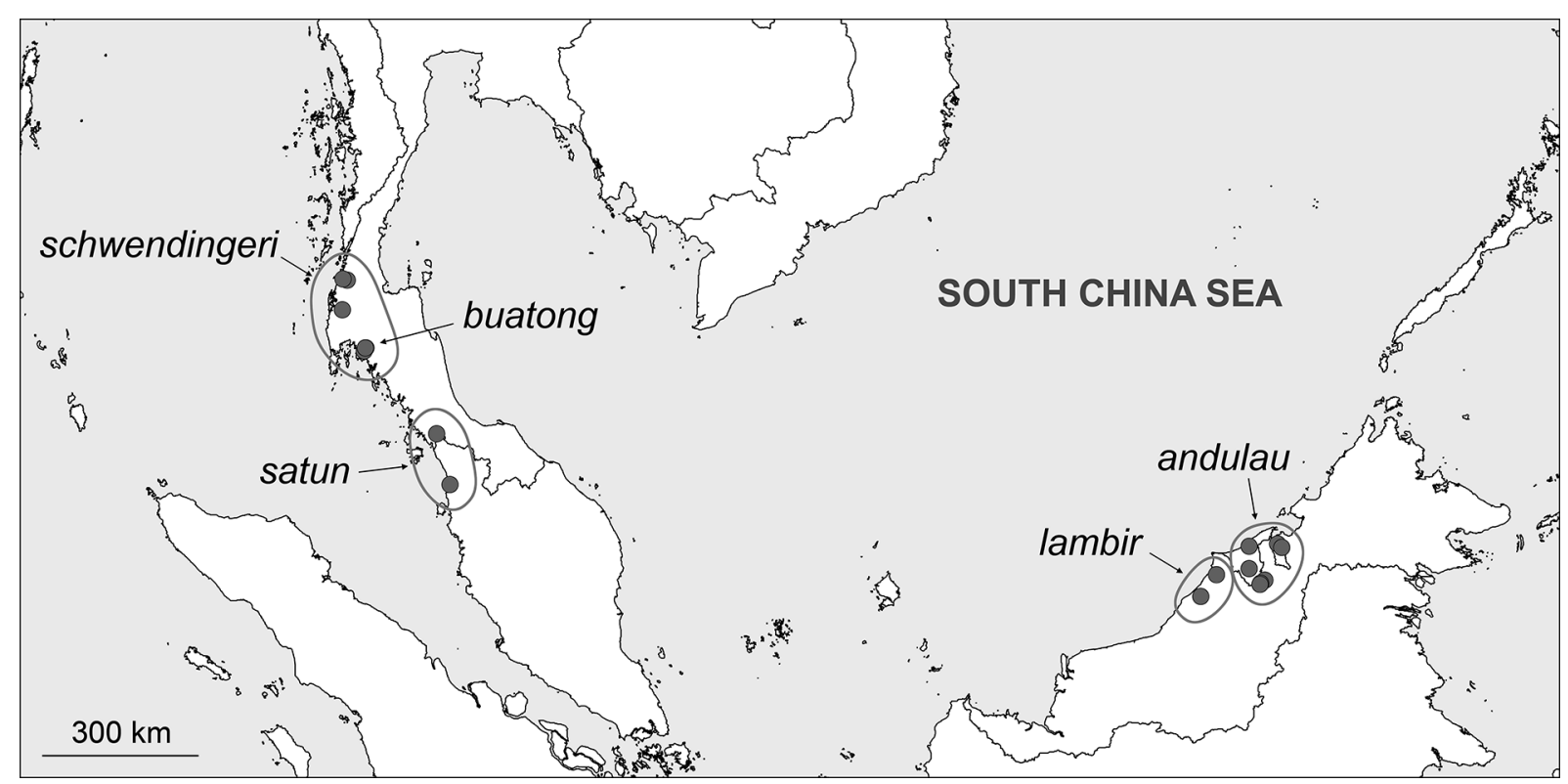

Fig. 153. Known distributions of the Pholcus buatong species group (Malay Peninsula) and of the Pholcus andulau species group (northern Borneo). 
proximal sclerite, slender and simple appendix (Fig. 161), without uncus, with long weakly sclerotized embolus distally transparent.

LEGS. Without spines and curved hairs; few vertical hairs; retrolateral trichobothrium on tibia 1 at 4\%; prolateral trichobothrium absent on tibia 1, present on other tibiae; tarsus 1 with $>20$ pseudosegments,

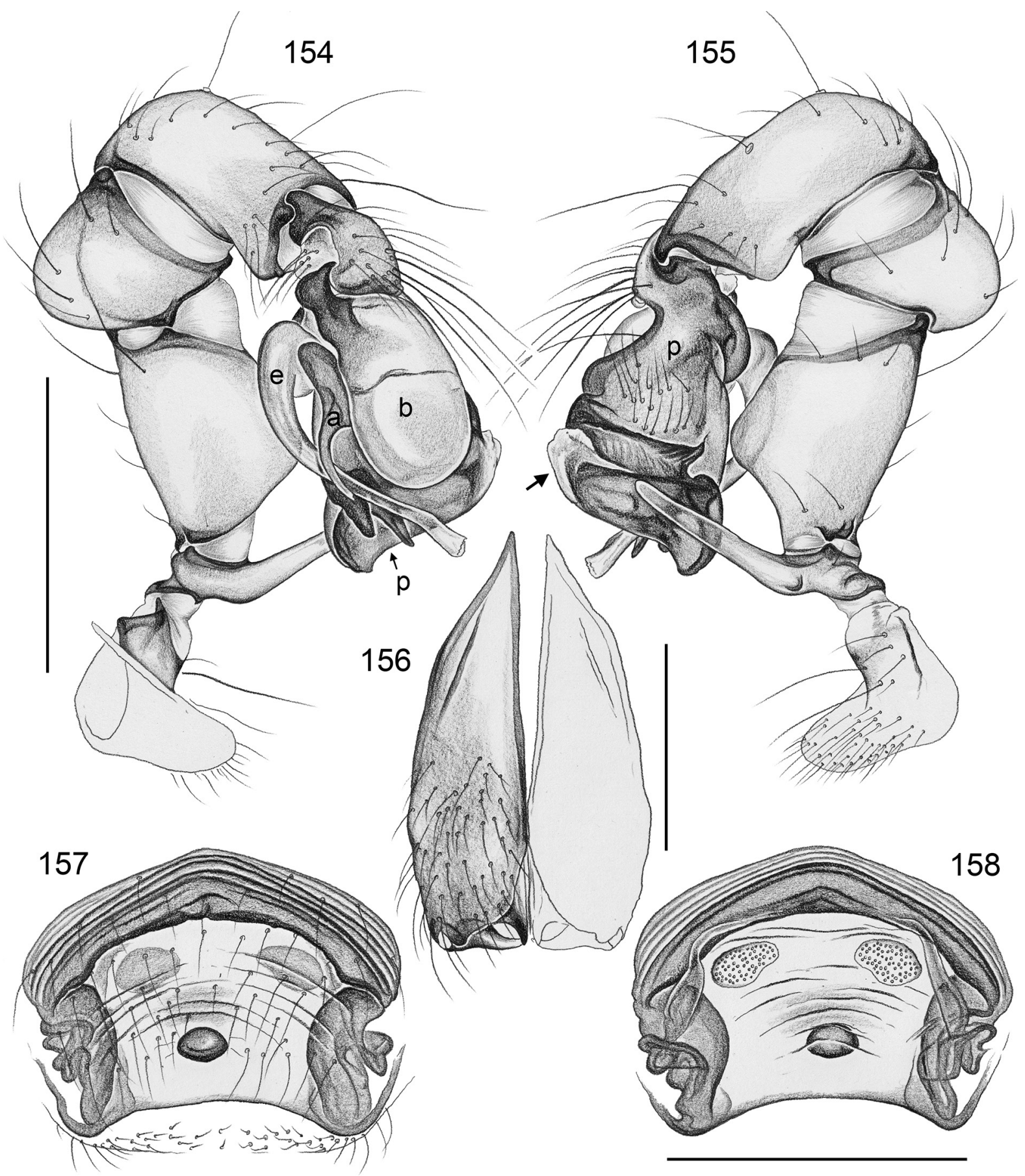

Figs 154-158. Pholcus buatong Huber, sp. nov., ZFMK Ar 15045. 154-155. Left male palp, prolateral and retrolateral views (arrow points at whitish membranous structure). 156. Male chelicerae, frontal view. 157-158. Cleared female genitalia, ventral and dorsal views. Abbreviations: a = appendix; $\mathrm{b}=$ genital bulb; $\mathrm{e}=$ embolus; $\mathrm{p}=$ procursus. Scale lines: $0.3 \mathrm{~mm}$ (156), $0.5 \mathrm{~mm}(154-155,157-158)$. 

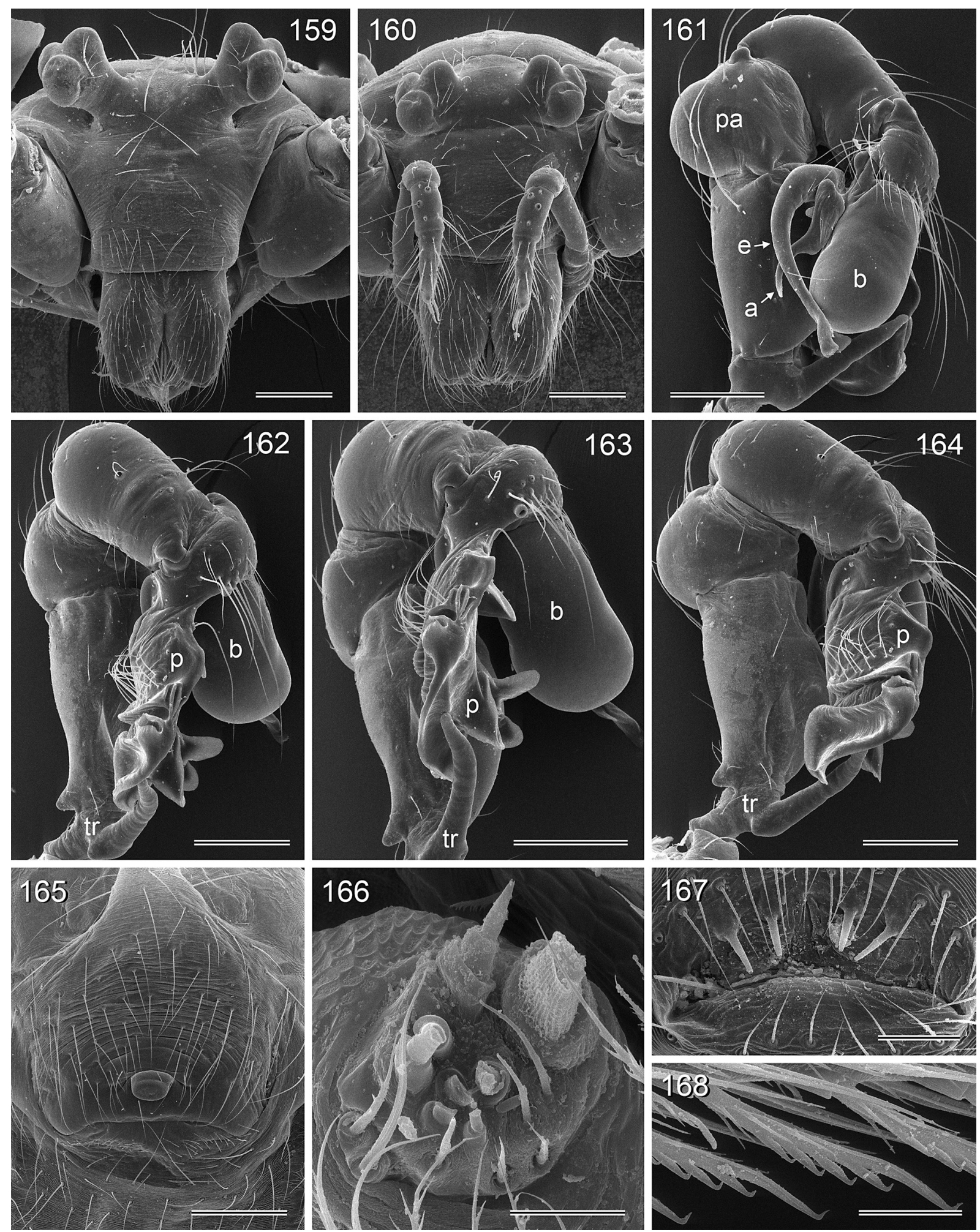

Figs 159-168. Pholcus buatong Huber, sp. nov., ZFMK Ar 15045. 159-160. Male and female prosomata, frontal views. 161. Left male palp, prolateral view. 162-164. Right male palp, retrolatero-dorsal, dorsal, and retrolateral views. 165. Epigynum, ventral view. 166. Male ALS. 167. Male gonopore. 168. Combhairs on male tarsus 4. Abbreviations: $\mathrm{a}=$ appendix; $\mathrm{b}=$ genital bulb; $\mathrm{e}=$ embolus; $\mathrm{p}=$ procursus; $\mathrm{pa}=$ patella; $\operatorname{tr}=$ trochanter. Scale lines: $20 \mu \mathrm{m}(166,168) ; 40 \mu \mathrm{m}(167) ; 200 \mu \mathrm{m}(159-165)$. 
very indistinct. Tarsus 4 comb-hairs of the simplified Pholcus-type (cf. Huber \& Fleckenstein 2008), with four lateral tines (Fig. 168).

Male (variation)

Tibia 1 in 10 other males: $8.9-10.4$ (mean 9.7).

\section{Female}

In general similar to male (Fig. 145) but eye triads on low humps and closer together (Fig. 160; PMEPME distance: $200 \mu \mathrm{m}$ ). Tibia 1 in 5 females: 6.4-8.5 (mean 7.3). Epigynum weakly sclerotized flat plate with large conspicuous sclerotized 'knob' (Fig. 165), anterior arch and lateral internal sclerites visible through cuticle (Figs 157, 184-185); internal genitalia as in Figs 158 and 186, with large lateral sclerites and oval pore plates in rather anterior position.

\section{Natural history}

At Buatong Cave, most specimens were found in barely visible domed webs close to the rock surface. Only one specimen had its body tightly pressed against the rock surface. At Khao Phueng Cave, specimens were abundant in the cave entrance area (again in very fine webs) but not deeper in the cave.

\section{Distribution}

Known from two neighboring localities in Krabi Province, southern Thailand (Fig. 153).

Pholcus satun Huber, 2011

Figs 147-149, 169-170, 187-189

Pholcus satun Huber, 2011: 144, figs 515-516, 580-582 (ふ).

\section{Diagnosis}

Easily distinguished from all known congeners by long sickle-shaped bulbal process and by unique shape of procursus (long, S-shaped, with subdistal ventral pointed process; fig. 580 in Huber 2011); from other species in the buatong group also by longer than wide female internal genitalia (Fig. 170).

\section{New material examined}

THAILAND: 1 q, in absolute ethanol, ZFMK (Mal 328), Satun, Thaleban National Park (6 $6^{\circ} 42.6^{\prime} \mathrm{N}$, $100^{\circ} 10.2^{\prime}$ E) (type locality), forest near headquarters, $110 \mathrm{~m}$ a.s.l., leaf litter, 5 Mar. 2015 (B.A. Huber, B. Petcharad).

MALAYSIA: 1 , ZFMK (Ar 15047), Kedah, Gunung Jerai, forest near Sri Perigi Waterfall ( $5^{\circ} 48.3^{\prime} \mathrm{N}$, 100²4.6' E), 100-200 m a.s.1., 27 Feb. 2015 (B.A. Huber); 2 우, 1 juv., in absolute ethanol, ZFMK (Mal 288), same data; 1 § , ZFMK (Ar 15048), same data, collected penultimate, adult on 2-3 Mar. 2015.

\section{Description (female)}

In general similar to male (Fig. 149; cf. Huber 2011), but eye triads on low humps and closer together (distance PME-PME: $185 \mu \mathrm{m}$ ) and black mark at ocular area smaller. AME present as in male. Tibia 1 in 3 females: 5.5, 5.6, 6.1. Epigynum longer than wide, mostly weakly sclerotized, with large dark 'knob' at posterior margin, anterior internal arch visible through cuticle (Figs 169, 187-188); posterior plate laterally slightly more sclerotized. Internal genitalia as in Figs 170 and 189.

\section{Distribution}

Known from two localities in southern Thailand and northern mainland Malaysia (Fig. 153). 
Pholcus schwendingeri Huber, 2011

Figs 150-152, 171-183, 190-192

Pholcus schwendingeri Huber, 2011: 183-184, figs 761-763, 823-825 (ふ).

\section{Diagnosis}

Easily distinguished from congeners by combination of very long male eye stalks (Figs 173-174), by male palpal morphology (twisted segments; strong trochanter apophysis; procursus with large prolateral process; simple appendix; absence of uncus; Figs 178-180; see also figs 823-824 in Huber 2011); from other species in buatong group also by female internal genitalia (Fig. 192; wider than long in contrast to Ph. satun; with angular anterior 'valve' in contrast to Ph. buatong sp. nov.).

\section{New material examined}

THAILAND: $3 \widehat{\partial} \partial^{\lambda}, 9$ q, , ZFMK (Ar 15049-50), Ranong, Klong Nakha Wildlife Sanctuary (9॰27.6' N, $98^{\circ} 30.7^{\prime}$ E) (type locality), 40 m a.s.l., forest, leaf litter, 12 Mar. 2015 (B.A. Huber, B. Petcharad); 4 우, in absolute ethanol, ZFMK (Mal 362), same data; 20 추, 12 우, ZFMK (Ar 15051-52), Surat Thani, Khao Sok National Park, forest along nature trail $\left(8^{\circ} 54.8^{\prime} \mathrm{N}, 9^{\circ} 29.3^{\prime}-98^{\circ} 30.5^{\prime} \mathrm{E}\right)$, leaf litter, 110-160 m a.s.l., 11-12 Mar. 2015 (B.A. Huber, B. Petcharad); 3 우, 3 juvs, in absolute ethanol, ZFMK (Mal 355), same
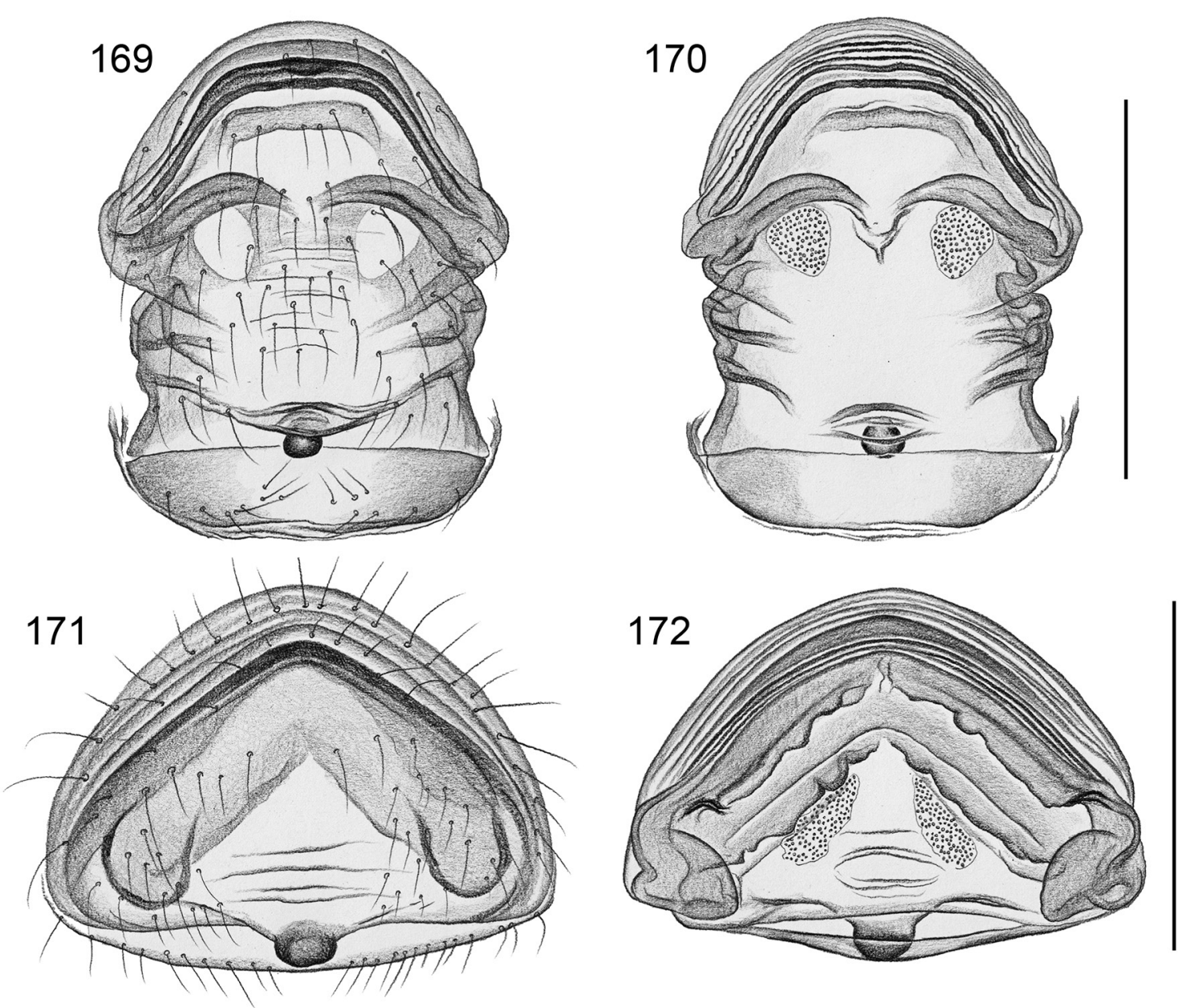

Figs 169-172. Cleared female genitalia, ventral and dorsal views. 169-170. Pholcus satun Huber, 2011, ZFMK 'Mal 328'. 171-172. Ph. schwendingeri Huber, 2011, ZFMK Ar 15050. Scale lines: 0.5 mm. 

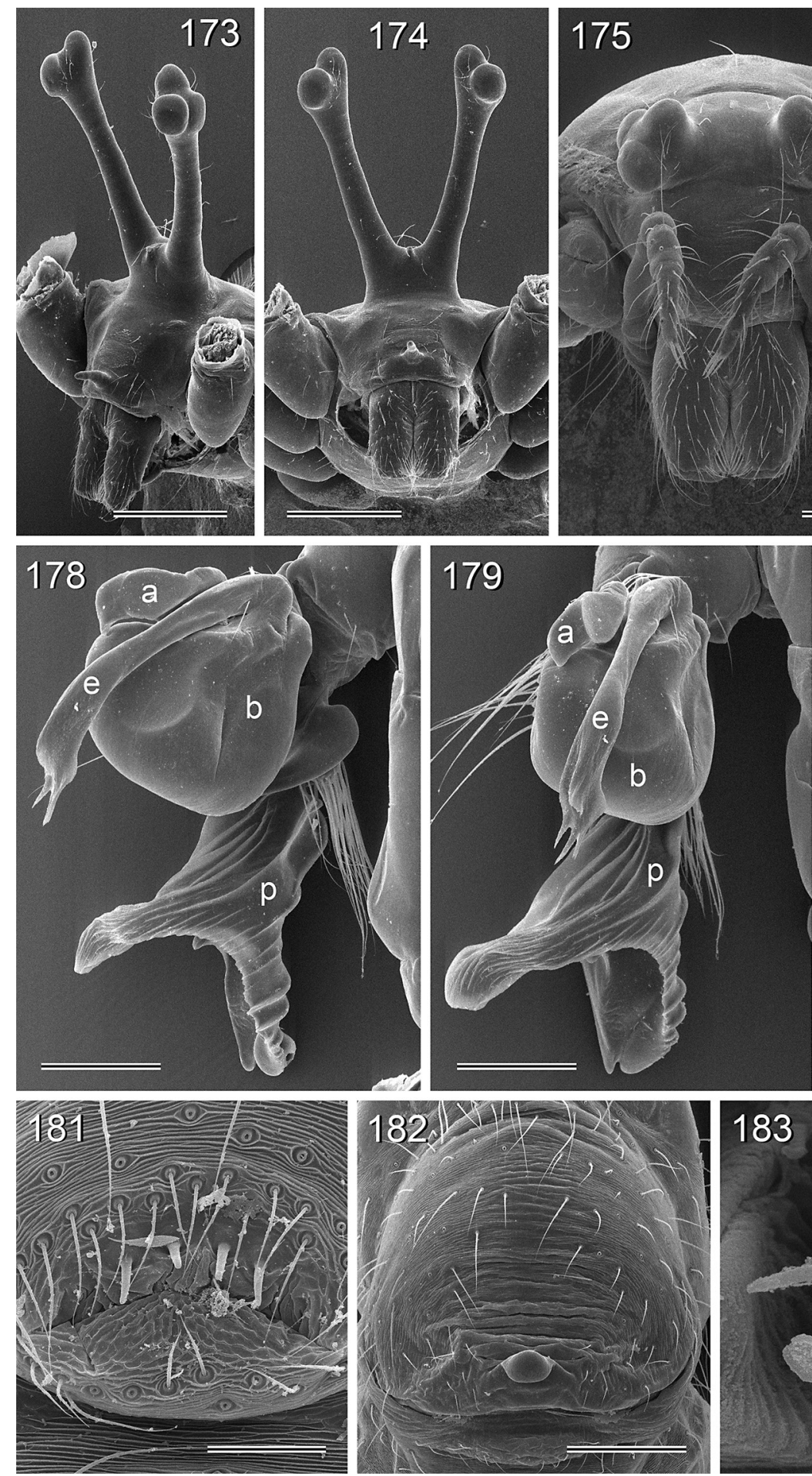
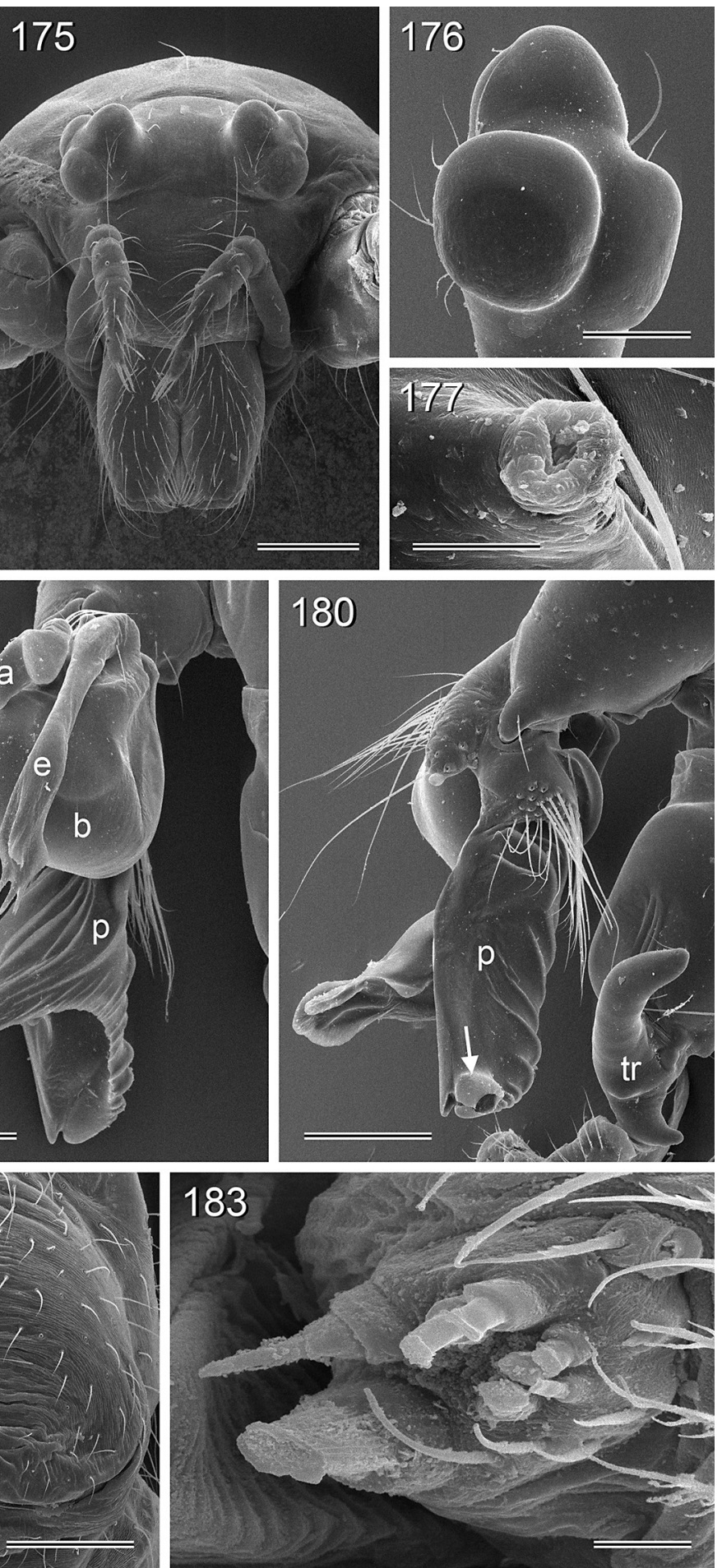

Figs 173-183. Pholcus schwendingeri Huber, 2011, ZFMK Ar 15051-52. 173-174. Male prosoma, oblique and frontal views. 175. Female prosoma, frontal view. 176. Male eye triad. 177. Process between male eye stalks. 178-179. Right genital bulb and procursus, prolateral and dorsal views. 180. Left palp, retrolateral view (arrow points at whitish membranous structure). 181. Male gonopore. 182. Epigynum, ventral view. 183. Female ALS. Abbreviations: $a=$ appendix; $b=$ genital bulb; $\mathrm{e}=$ embolus; $\mathrm{p}=$ procursus; $\operatorname{tr}=$ trochanter. Scale lines: $10 \mu \mathrm{m}(183) ; 20 \mu \mathrm{m}$ (177); $50 \mu \mathrm{m}$ (181); $80 \mu \mathrm{m}(176) ; 200 \mu \mathrm{m}(175,178-$ 180, 182); $400 \mu \mathrm{m}(173-174)$. 


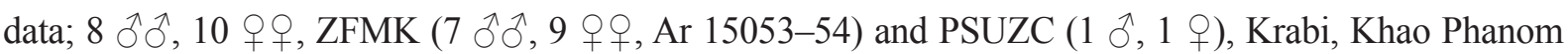
Bencha National Park, trails near headquarters ( $\left.8^{\circ} 14.1^{\prime} \mathrm{N}, 98^{\circ} 55.1^{\prime} \mathrm{E}\right), 150-300 \mathrm{~m}$ a.s.l., leaf litter in forest, 8 Mar. 2015 (B.A. Huber, B. Petcharad); 5 우, 1 juv., in absolute ethanol, ZFMK (Mal 339), same data; 1 §̂, RMNH, Khao Phanom Bencha National Park, 15 Dec. 1990 (C.L. \& P.R. Deeleman).

\section{Description}

\section{Male - amendments}

Males from Khao Sok are significantly larger than males from Phanom Bencha: tibia 1 in 19 males from Khao Sok: 7.4-8.9 (mean 8.0); in 7 males from Phanom Bencha: 6.6-7.3 (mean 7.0). This difference
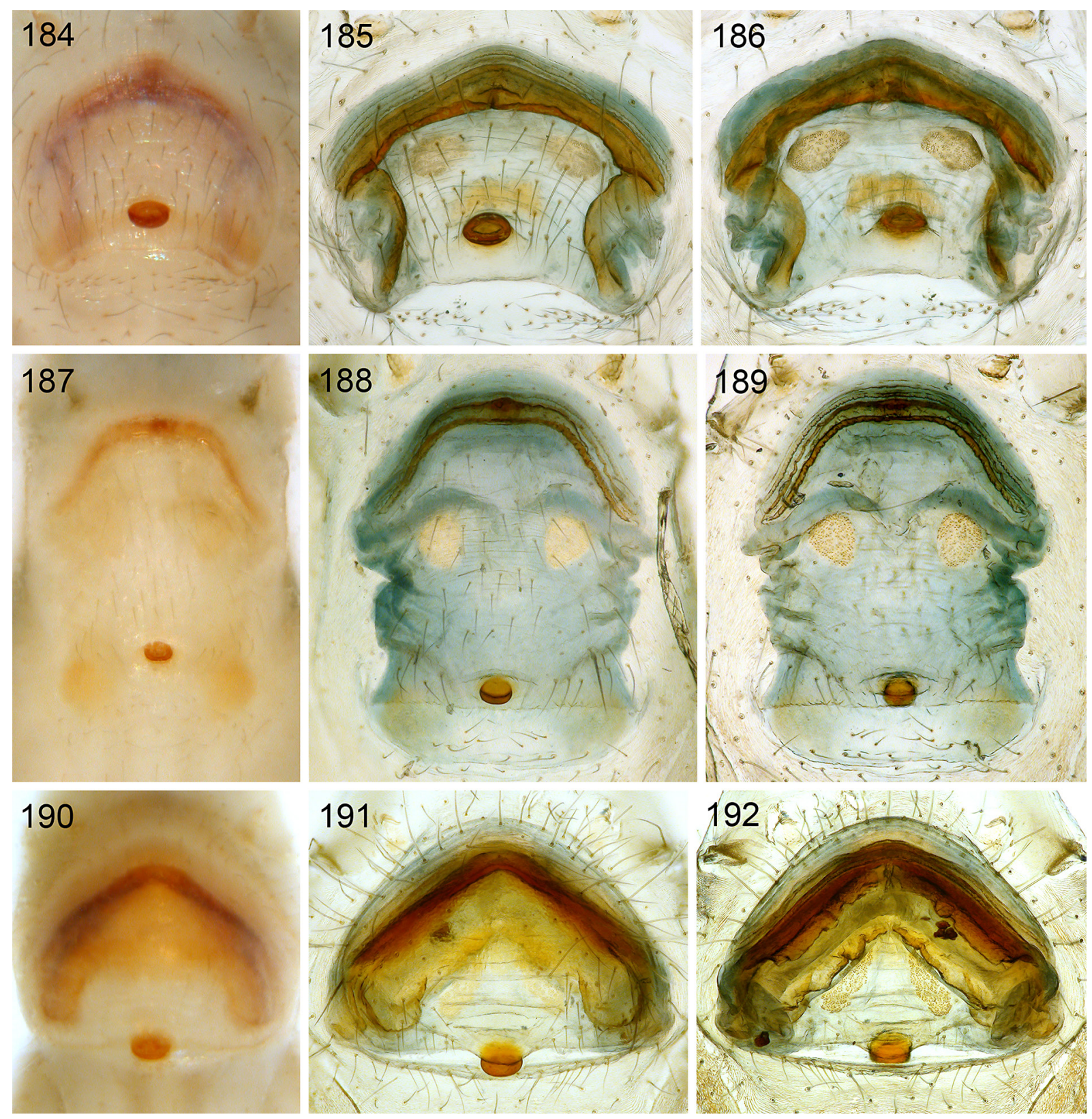

Figs 184-192. Female genitalia, untreated in ventral view, cleared in ventral and dorsal views. 184186. Pholcus buatong Huber, sp. nov. 187-189. Ph. satun Huber, 2011. 190-192. Ph. schwendingeri Huber, 2011. 
is even more pronounced in eye stalk length: in 19 males from Khao Sok: 0.70-0.78 (mean 0.74); in 8 males from Phanom Bencha: 0.53-0.60 (mean 0.55). Males from Klong Nakha seem to be intermediate (low sample size). Angle between eye stalks varies even within localities (compare Figs 150 and 151). All males with process between eye stalks (Fig. 177). Male tibia 2/tibia 4 length: 1.08. Patella dorsally widened, resulting in an angle between femur and patella of $\sim 125^{\circ}$ (lateral view; in figures 823 and 824 in Huber 2011, femora and patellae are not in perfect lateral view). Male gonopore with four epiandrous spigots (Fig. 181). ALS as in female (see below).

\section{Female}

In general similar to male (Fig. 152), but eye triads on low humps and closer together (Fig. 175; distance PME-PME: $185 \mu \mathrm{m}$ ); black marks in place of AME, but without lenses; clypeus unmodified. Tibia 1 in 10 females from Khao Sok: 5.6-6.3 (mean 6.0); in 9 females from Klong Nakha: 5.3-6.3 (mean: 5.7); in 10 females from Phanom Bencha: 4.7-5.5 (mean 5.3). Epigynum wider than long, mostly weakly sclerotized, with large dark 'knob' at posterior margin (Fig. 182), anterior internal arch visible through cuticle (Figs 171, 190-191). Internal genitalia as in Figs 172 and 192. ALS with one widened, one pointed, and several (apparently six) smaller cylindrically-shaped spigots of varying sizes (Fig. 183).

\section{Natural history}

At all three localities, the species was fairly abundant in suitable forest patches with large numbers of large dead leaves on the ground. The poorly visible webs were closely attached to the lower leaf surface. The spiders barely reacted to disturbance.

\section{Distribution}

Known from three localities in southern Thailand (Fig. 153).

\section{Pholcus andulau species group}

This species group is newly proposed to include one species previously included in the Ph. halabala group (Ph. andulau Huber, 2011) and the newly described Ph. lambir Huber, sp. nov. They share three putative synapomorphies: (1) the unique, partly sclerotized embolus with strong sclerotized pointed processes (Figs 200, 209-212); (2) pointed male cheliceral apophyses directed toward each other and without modified hairs (Figs 202, 214); and (3) large unsclerotized 'knob' on female external genitalia directed toward anterior (Figs 203, 213). The two species are also otherwise very similar (females are indistinguishable in the field; Ph. lambir sp. nov. males have a darker ocular area than Ph. andulau males) and restricted to a limited geographic area in northern Borneo (Fig. 153). Preliminary molecular data (A. Valdez-Mondragón, B.A. Huber \& D. Dimitrov unpublished data) suggest a close relationship with the Panjange nigrifrons group (which is also restricted to Borneo), but we know of no putative morphological synapomorphy that would support this relationship. However, general habitus and coloration are almost identical, and the same is true of web structure and microhabitat: in both groups, the spiders build domed webs among the vegetation, with the apex of the sheet connected to the underside of a leaf. In addition, they hang in their webs under the leaf rather than having their bodies pressed against the leaf, and in both groups, cecidomyiid flies were often seen in large numbers hanging in the spider webs. When disturbed, Pholcus andulau and Ph. lambir sp. nov. vibrate vigorously. Egg-sacs are carried in front of the body (Figs 194, 196), as in typical pholcids.

Pholcus andulau Huber, 2011

Figs 193-194

Pholcus andulau Huber, 2011: 141-142, figs 502-504, 521-522, 570-574 (ぷ゚). 


\section{Diagnosis}

Easily distinguished from putatively closest known relative (Ph. lambir sp. nov.) by long dorsal process on procursus (fig. 571 in Huber 2011), by smaller sclerotized teeth on male embolus (fig. 570 in Huber 2011), and by strongly curved anterior sclerite in internal female genitalia (fig. 573 in Huber 2011).

\section{New material examined}

MALAYSIA-BORNEO: 3 ふぇ, 6 우, ZFMK (Ar 15055-56), Sarawak, Gunung Mulu National Park, Paku Waterfall Trail (4.037 $\left.\mathrm{N}, 114.823^{\circ} \mathrm{E}\right), 60 \mathrm{~m}$ a.s.l., in domed webs under leaves, 23 Jul. 2014 (B.A. Huber, S.B. Huber); 3 우, in absolute ethanol, ZFMK (Bor 239), same data; 2 ऽึ 1 우, ZFMK (Ar 15057), Gunung Mulu National Park, forest near Lagang Cave ( $\left.4.051^{\circ} \mathrm{N}, 114.822^{\circ} \mathrm{E}\right), 60 \mathrm{~m}$ a.s.1., domed webs under leaves, 24 Jul. 2014 (B.A. Huber, S.B. Huber); 1 q, ZFMK (Ar 15058), Gunung Mulu National Park, forest near Deer Cave $\left(4.027^{\circ} \mathrm{N}, 114.818^{\circ} \mathrm{E}\right), 60 \mathrm{~m}$ a.s.l., night collecting, $24 \mathrm{Jul}$. 2014 (B.A. Huber); 1 ठ, RMNH, Gunung Mulu National Park, 12-22 Oct. 2003 (C.L. \& P.R. Deeleman).

BRUNEI: 1 +, RMNH, Temburong, Bukit Betoi, “87.04.23.06”.
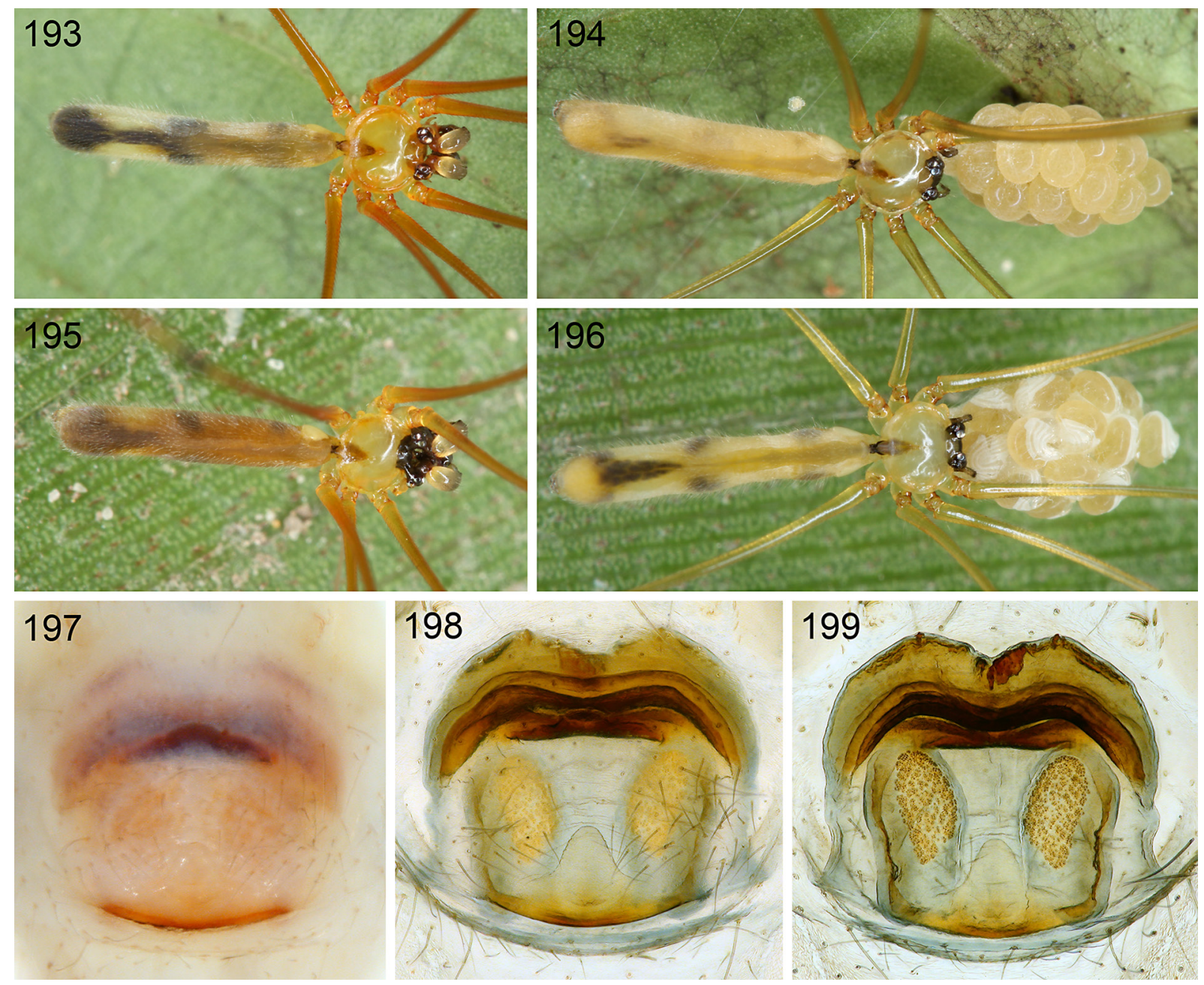

Figs 193-199. Live specimens, Pholcus andulau group, and female genitalia of Ph. lambir Huber, sp. nov. 193-194. Pholcus andulau Huber, 2011, $\sigma^{-}$and + with egg-sac from Gunung Mulu, Sarawak. 195-196. Ph. lambir sp. nov., $\delta$ and $q$ with egg-sac from Lambir, Sarawak. 197-199. Ph. lambir sp. nov., female genitalia, untreated in ventral view, cleared in ventral and dorsal views. 


\section{Distribution}

Known from several localities in Brunei and northeastern Sarawak (Fig. 153).

Pholcus lambir Huber, sp. nov. urn:1sid:zoobank.org:act:2B969B98-2995-4325-911C-D3013371FFE3

Figs 195-218

\section{Diagnosis}

Easily distinguished from putatively closest known relative (Ph. andulau) by very short dorsal (slightly prolateral) process on procursus (Fig. 200), by much larger sclerotized teeth on male embolus (Figs 200, 209-212), and by less curved anterior sclerite in internal female genitalia (Figs 197-199).

\section{Etymology}

The species name is derived from the type locality; noun in apposition.

\section{Type material}

MALAYSIA-BORNEO: holotype, đ̂, ZFMK (Ar 15059), Sarawak, Lambir Hills National Park (4.198$4.207^{\circ} \mathrm{N}, 114.034-114.045^{\circ} \mathrm{E}$ ), 60-150 m a.s.l., in domed webs under leaves, 22 Jul. 2014 (B.A. Huber, S.B. Huber).

\section{Other material examined}

MALAYSIA-BORNEO: $9 \hat{\jmath} \widehat{\partial}, 13$ $q$ ㅇ, 1 juv., ZFMK ( $8 \hat{\jmath} \hat{\jmath}, 12$ 우, $\operatorname{Ar} 15060-61)$ and SMK $(1 \hat{\jmath}$, 1 ㅇ) , same data as holotype; $1 \hat{\jmath}, 2$ 웅, in absolute ethanol, ZFMK (Bor 200), same data; $3 \hat{\jmath},, 8$ 우으,

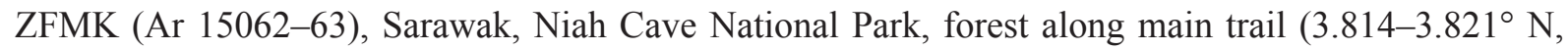
113.763-113.771 ${ }^{\circ}$ E), 20-40 m a.s.l., domed webs under leaves, 27 Jul. 2014 (B.A. Huber, S.B. Huber).

\section{Description}

\section{Male (holotype)}

Measurements. Total body length 5.0, carapace width 1.05. Leg 1: $48.4(10.6+0.5+11.0+23.5+2.8)$, tibia 2: 6.9, tibia 3: 4.0, tibia 4: 6.2; tibia $1 \mathrm{~L} / \mathrm{d}: 100$. Distance PME-PME $380 \mu \mathrm{m}$, diameter PME $100 \mu \mathrm{m}$, distance PME-ALE $40 \mu \mathrm{m}$; AME absent (only small irregular internal black marks).

CoLor. Carapace pale ochre-yellow, ocular area and clypeus brown; sternum whitish; legs ochre-yellow to orange, with brown patellae and tibia-metatarsus joints; abdomen ochre-gray with some darker marks dorsally, monochromous ventrally.

Body. Habitus as in Fig. 195; ocular area slightly raised and each triad on short stalk directed obliquely dorsad (Fig. 205); carapace without median furrow; clypeus unmodified; sternum wider than long $(0.80 / 0.65)$, unmodified. Gonopore with four epiandrous spigots (Fig. 216). ALS with one widened, one pointed, and six smaller cylindrically shaped spigots of varying sizes (Fig. 218).

Chelicerae. As in Fig. 202, with distinctive pair of pointed frontal apophyses directed toward each other (Fig. 214); indistinct lateral processes.

PaLPs. As in Figs 200-201; coxa unmodified; trochanter with retrolatero-ventral apophysis; femur with distinctive ventral process directed proximad; procursus relatively simple, with small semitransparent prolateral process (Figs 207-209) and distinctive sclerotized and membranous distal elements; bulb large, with strong proximal sclerite, with uncus, with proximally heavily sclerotized embolus provided with strong teeth (Figs 209-212). 


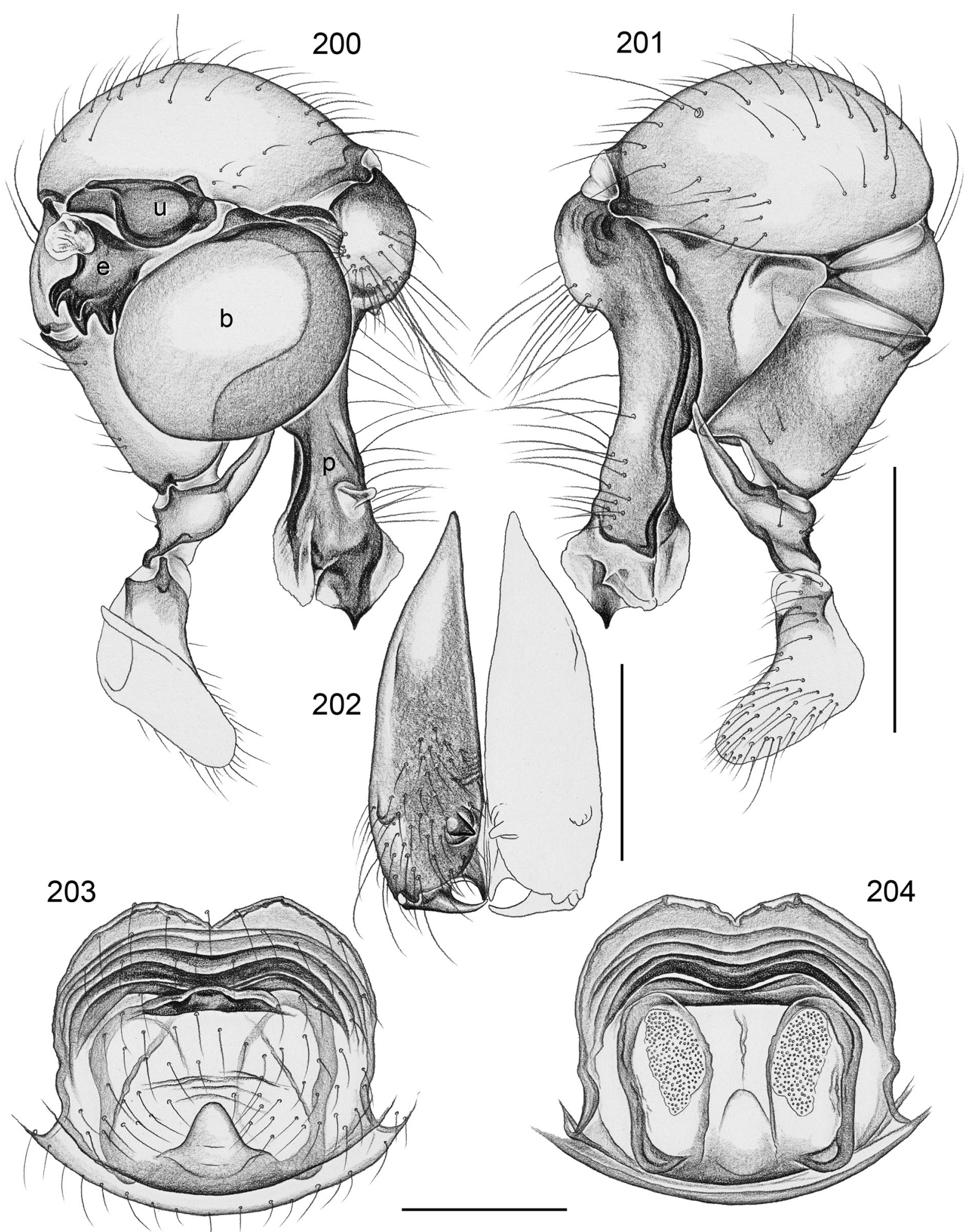

Figs 200-204. Pholcus lambir Huber, sp. nov., ZFMK Ar 15060-61. 200-201. Left male palp, prolateral and retrolateral views. 202. Male chelicerae, frontal view. 203-204. Cleared female genitalia, ventral and dorsal views. Abbreviations: $\mathrm{b}=$ genital bulb; $\mathrm{e}=$ embolus; $\mathrm{p}=$ procursus; $\mathrm{u}=$ uncus. Scale lines: $0.3 \mathrm{~mm}(202-204), 0.5 \mathrm{~mm}(200-201)$. 
Legs. Without spines and curved hairs; few vertical hairs; retrolateral trichobothrium on tibia 1 at $2 \%$; prolateral trichobothrium absent on tibia 1, present on other tibiae; tarsus 1 pseudosegments very indistinct, only distally a few visible in dissecting microscope. Tarsus 4 comb-hairs of the simplified Pholcus-type (cf. Huber \& Fleckenstein 2008), with four lateral tines (Fig. 215).

Male (variation)

Tibia 1 in 9 other males: 9.6-11.7 (mean 10.5).

\section{Female}

In general similar to male (Fig. 196), but eye triads on low humps and closer together (Fig. 206; PME-PME distance: $200 \mu \mathrm{m}$ ), clypeus darker than in males. Tibia 1 in 20 females: $6.8-8.8$ (mean 8.0). Epigynum weakly sclerotized flat plate with large unsclerotized 'knob' directed toward anterior (Fig. 213), anterior internal sclerite visible through cuticle (Figs 197-198, 203); internal genitalia as in Figs 199 and 204. ALS as in male (Fig. 217).
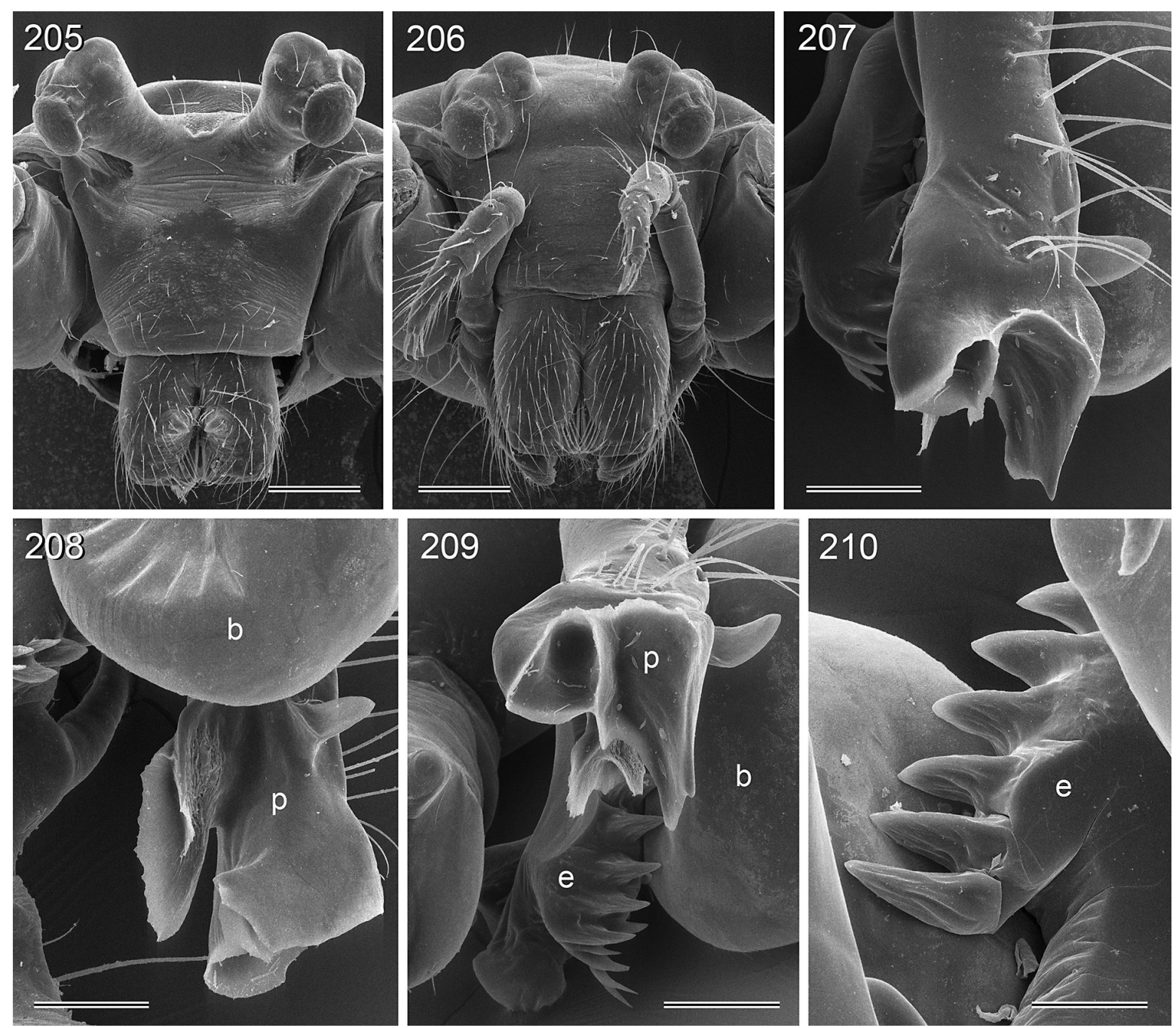

Figs 205-210. Pholcus lambir Huber, sp. nov., ZFMK Ar 15060-61. 205-206. Male and female prosomata, frontal views. 207. Right procursus, retrolateral (slightly dorsal) view. 208. Left procursus (and genital bulb), prolateral view. 209. Right procursus (and embolus sclerite), distal view. 210. Right embolus sclerite, prolateral view. Abbreviations: $\mathrm{b}=$ genital bulb; $\mathrm{e}=$ embolus; $\mathrm{p}=$ procursus. Scale lines: $50 \mu \mathrm{m}$ (210); $100 \mu \mathrm{m}$ (207-209); $200 \mu \mathrm{m}$ (205-206). 


\section{Natural history}

Spiders were collected from domed webs among the vegetation, at approximately $1-2 \mathrm{~m}$ above the ground. The apex of the sheet was connected to the underside of a leaf, but spiders hung in their webs under the leaf rather than having their bodies pressed against the leaf. In some webs, cecidomyiid flies
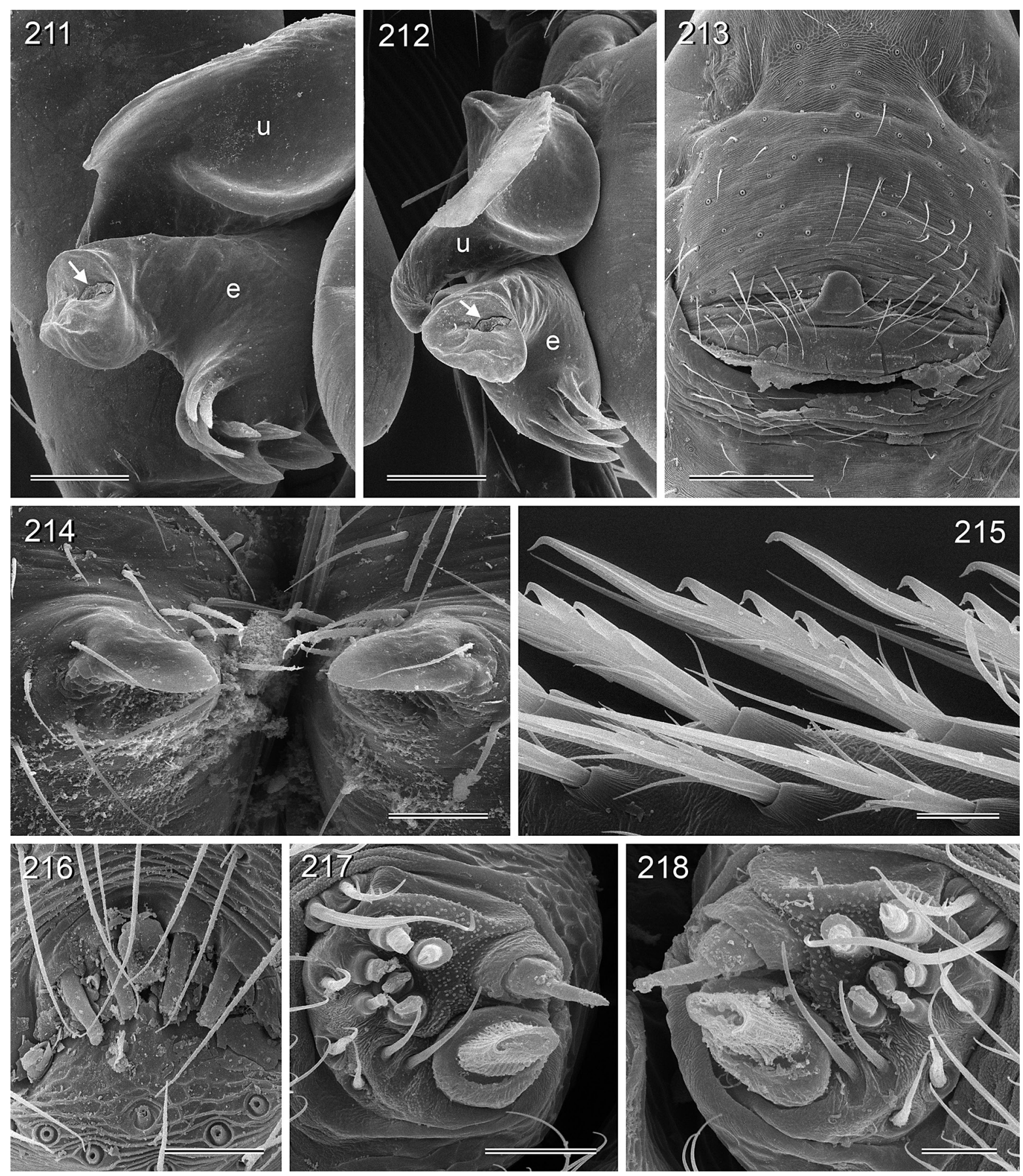

Figs 211-218. Pholcus lambir Huber, sp. nov., ZFMK Ar 15060-61. 211-212. Left bulbal processes, prolateral (slightly distal) and ventral views (arrows point at sperm duct opening). 213. Epigynum, ventral view. 214. Distal male cheliceral apophyses. 215. Comb-hairs on male tarsus 4. 216. Male gonopore. 217-218. Female and male ALS. Abbreviations: $\mathrm{e}=$ embolus; $\mathrm{u}=$ uncus. Scale lines: $10 \mu \mathrm{m}$ (215, 218); $20 \mu \mathrm{m}$ (217); $30 \mu \mathrm{m}(214,216) ; 60 \mu \mathrm{m}$ (211); $80 \mu \mathrm{m}$ (212); $200 \mu \mathrm{m}$ (213). 
were seen and collected in large numbers. When disturbed, the spiders vibrated vigorously. Egg-sacs were carried in front of the body (Fig. 196), as in typical pholcids; they are slightly elongate and contain 25-30 eggs.

\section{Distribution}

Known from two localities in northeastern Sarawak (Fig. 153).

\section{Discussion}

An unrevised genus with more than 300 described and probably hundreds of undescribed species like Pholcus is notoriously difficult to handle: internal relationships are mostly entirely obscure; decisions whether newly collected specimens represent new species or not are difficult or impossible to make; and biological peculiarities cannot be interpreted in an evolutionary context. For more than 200 years, isolated species descriptions were added to Pholcus, not only without any phylogenetic framework, but often even without the chance to compare new species with the most similar 'known' congeners. The result was more akin to a long list of biologically relatively meaningless names than to testable hypotheses about natural groups, species limits, and evolutionary trends within the genus. This was unfortunate not only because it led to synonyms and chaos, but mainly because Pholcus is characterized by numerous biologically interesting phenomena whose evolution will only be understood in the context of a phylogenetic framework. For example, (1) several different kinds of male 'head' modifications have evolved within the genus, including spines, hooks, eye stalks, and curiously modified hair brushes (Huber 2011), but the evolution of these structures is barely understood; (2) different Pholcus species appear to specialize in specific microhabitats, such as leaf litter, dark and sheltered spaces under logs and rocks, open space among vegetation, undersides of green leaves, and rock surfaces. Shifts among these microhabitats and the potential effects of the underlying evolutionary ecological flexibility on species diversification remain largely unknown (Dimitrov et al. 2013).

A first major effort to bring structure into the taxonomic chaos of Pholcus was made in Huber (2011). Many 'old' and poorly known species were redescribed; first SEM data were provided for numerous species; and the genus was divided into 29 operational species groups, based partly on synapomorphies derived from a first cladistic analysis, partly on putative synapomorphies not derived from formal analysis, and partly just on similarity and geographic closeness. Obviously, this preliminary analysis was just a first step that requires substantial further refinement to approximate the true phylogenetic history of the genus. More light could have been shed if the nine taxonomic contributions on Pholcus published since 2011 (mostly on Chinese, Korean, and Vietnamese species) had considered anything beyond pure alpha taxonomy, such as phylogenetic relations, distribution patterns, diversity patterns, evolution of character systems, or any other questions of biological interest. Instead, none of them even attempted to place new species into existing species groups. We do not claim that such purely descriptive work is worthless, but we agree with Darlington (1971:347) that "describing of scattered new species in poorly known groups is often not useful" and with Mayr \& Ashlock (1991: 347) that "isolated description [...] divorced from revisional or monographic work is the least desirable form of taxonomic publication".

This contribution deals mainly with the Pholcus halabala group, originally considered one of the most problematic (i.e., unnatural or non-monophyletic) species groups in Pholcus. The combination of field observations (web design and structure, microhabitat, egg-sac holding position, life color pattern), ultrastructure (silk spigots, male cheliceral apophyses), and general morphology (abdomen shape) have prompted us to completely rearrange the group and to propose three new species groups. We explicitly point out the remaining gaps that need to be addressed, and highlight a number of potentially useful characters (those listed above) in this and related species groups for future formal cladistic analyses. The fact that some of these characters can only be observed in life specimens in the field underlines 
the importance of continued and focused field work beyond the "accumulation of dead specimens" (cf. Darlington 1971). Future work should especially focus on the Pholcus quinquenotatus group. Three of the species we newly assign to the Ph. halabala group were originally (Huber 2011) proposed as representatives of the Ph. quinquenotatus group. This leaves three species in the Ph. quinquenotatus group, but field observations (and molecular data) may suggest that at least two of them are also part of the Ph. halabala group (Ph. quinquenotatus Thorell, 1878; Ph. namou Huber, 2011), making the Ph. quinquenotatus group obsolete.

\section{Acknowledgements}

We thank David Court, Venus Saksongmuang, Mustakiza Muslimin, Kamil A. Braima, and Samuel B. Huber for accompanying us in the field; our Thai drivers Usman Hayee-Aarwae, Jeerabute Suwannatut, and Preesha Petsout for bringing us safely to all requested places; Björn Rulik for identifying the flies found in pholcid webs; Sara Bumrungsri for supporting our permit requests in Thailand; Noraishah Mydin Abdul Aziz for facilitating field work in Malaysia; the Sarawak Museum Department for assistance in field logistics; the National Research Council of Thailand (NRCT), the Singapore National Parks Board (Permit No. NP/RP15-003a) and the Sarawak Forest Department (Permit No. NCCD.907.4.4 JLD.10211, Park Permit No. 174/2014) for issuing the relevant permits; two anonymous reviewers for valuable comments on a previous version of the manuscript; and the German Research Foundation for financial support (DFG Project HU 980/11-1).

\section{References}

Brown B.V. 1993. A further chemical alternative to critical-point-drying for preparing small (or large) flies. Fly Times 11: 10.

Darlington P.J. 1971. Modern taxonomy, reality, and usefulness. Systematic Zoology 20 (3): 341-365. http://dx.doi.org/10.2307/2412346

Dimitrov D., Astrin J.J. \& Huber B.A. 2013. Pholcid spider molecular systematics revisited, with new insights into the biogeography and the evolution of the group. Cladistics 29 (2): 132-146. http://dx.doi. org/10.1111/j.1096-0031.2012.00419.x

Huber B.A. 2011. Revision and cladistic analysis of Pholcus and closely related taxa (Araneae, Pholcidae). Bonner zoologische Monographien 58: 1-509.

Huber B.A. 2012. Revision and cladistic analysis of the Afrotropical endemic genus Smeringopus Simon, 1890 (Araneae: Pholcidae). Zootaxa 3461: 1-138.

Huber B.A. \& Fleckenstein N. 2008. Comb-hairs on the fourth tarsi in pholcid spiders (Araneae, Pholcidae). Journal of Arachnology 36: 232-240. http://dx.doi.org/10.1636/CSh07-71.1

Mayr E. \& Ashlock P.D. 1991. Principles of Systematic Zoology. 2nd edition. McGraw-Hill, New York.

Walckenaer C.A. 1805. Tableau des aranéides ou caractères essentiels des tribus, genres, familles et races que renferme le genre Aranea de Linné, avec la désignation des espèces comprises dans chacune de ces divisions. Imprimerie de Dentu, Paris.

World Spider Catalog 2015. World Spider Catalog. Natural History Museum Bern. Available online at http://wsc.nmbe.ch, version 16.5. [accessed 8 Dec. 2015]

Manuscript received: 9 October 2015

Manuscript accepted: 19 December 2015

Published on: 14 April 2016 
Topic editor: Rudy Jocqué

Desk editor: Charlotte Thionois

Printed versions of all papers are also deposited in the libraries of the institutes that are members of the EJT consortium: Muséum national d'Histoire naturelle, Paris, France; Botanic Garden Meise, Belgium; Royal Museum for Central Africa, Tervuren, Belgium; Natural History Museum, London, United Kingdom; Royal Belgian Institute of Natural Sciences, Brussels, Belgium; Natural History Museum of Denmark, Copenhagen, Denmark. 